Georgia State University

ScholarWorks @ Georgia State University

$5-6-2020$

\title{
Dynamic Capabilities in Microfinance Innovation: A Case Study of The Grameen Foundation
}

Sarah Kayongo

Follow this and additional works at: https://scholarworks.gsu.edu/bus_admin_diss

\section{Recommended Citation}

Kayongo, Sarah, "Dynamic Capabilities in Microfinance Innovation: A Case Study of The Grameen Foundation." Dissertation, Georgia State University, 2020.

doi: https://doi.org/10.57709/17701950

This Dissertation is brought to you for free and open access by the Programs in Business Administration at ScholarWorks @ Georgia State University. It has been accepted for inclusion in Business Administration Dissertations by an authorized administrator of ScholarWorks @ Georgia State University. For more information, please contact scholarworks@gsu.edu. 


\section{PERMISSION TO BORROW}

In presenting this dissertation as a partial fulfillment of the requirements for an advanced degree from Georgia State University, I agree that the Library of the University shall make it available for inspection and circulation in accordance with its regulations governing materials of this type. I agree that permission to quote from, copy from, or publish this dissertation may be granted by the author or, in her absence, the professor under whose direction it was written or, in his absence, by the Dean of the Robinson College of Business. Such quoting, copying, or publishing must be solely for scholarly purposes and must not involve potential financial gain. It is understood that any copying from or publication of this dissertation that involves potential gain will not be allowed without written permission of the author.

Sarah Elizabeth Kayongo 


\section{NOTICE TO BORROWERS}

All dissertations deposited in the Georgia State University Library must be used only in accordance with the stipulations prescribed by the author in the preceding statement.

The author of this dissertation is:

Sarah Elizabeth Kayongo ${ }^{\text {TM }}$

1342 Turtlebrook Lane

Lawrenceville, GA 30043

The director of this dissertation is:

Dr. Lars Mathiassen

J. Mack Robinson College of Business

Georgia State University

Atlanta, GA 30302-4015 
Dynamic Capabilities in Microfinance Innovation: A Case Study of The Grameen Foundation

by

Sarah Elizabeth Kayongo

A Dissertation Submitted in Partial Fulfillment of the Requirements for the Degree

Of

Executive Doctorate in Business

In the Robinson College of Business

Of

Georgia State University

GEORGIA STATE UNIVERSITY

ROBINSON COLLEGE OF BUSINESS

2020 
Copyright by

Sarah Elizabeth Kayongo

2020 


\section{ACCEPTANCE}

This dissertation was prepared under the direction of the SARAH ELIZABETH

KAYONGO Dissertation Committee. It has been approved and accepted by all members of that committee, and it has been accepted in partial fulfillment of the requirements for the degree of

Doctor of Philosophy in Business Administration in the J. Mack Robinson College of Business of Georgia State University.

Richard Phillips, Dean

\section{DISSERTATION COMMITTEE}

Dr. Lars Mathiassen (Chair)

Dr. Subhashish Samaddar

Dr. Denish Shah 


\section{DEDICATION}

I would like to thank my family for patiently enduring my absence, particularly my beloved children Kevin and Lauren Kayongo who were rapidly growing teenagers as I embarked on this journey. I thank my brother Dr. Abimereki D. Muzaale for the numerous discussions we had as we explored metaphors that bridged the gap between my business world to his medical world, thereby revealing the essence of professional service delivery. I am grateful to my parents Professor Patrick J. Muzaale and Lucy J. Muzaale for instilling in me at a very early age the values of faith, love, and the pursuit of excellence. My siblings Rosemary, Charles, Andrew (R.I.P.), Harriet, Patrick, Martin, and Abimereki have served as exemplars of a generation decisively evolving from the remote villages of Busoga into vibrant cosmopolitan citizens.

Most importantly, I dedicate this work to the one who deserves all the praise and glory, God Almighty! Ephesians 3:20 (KJV) "Now unto him that is able to do exceeding abundantly above all that we ask or think, according to the power that worketh in us." 


\section{ACKNOWLEDGEMENTS}

The contents of this dissertation are the outcome of my thinking after fifteen years as a business manager, initially in not-for-profit international organizations but later in for-profit international organizations as well. They reflect the totality of my experience, background and beliefs, and so, no doubt, my Ugandan origins, early East African education, and ultimately my graduate school experience in the United States.

I should like to pay tribute to all those who have influenced my professional development. I owe special gratitude to my dissertation chair and mentor Professor Lars Mathiassen for finding value in my initial ideas and guiding me through to the end of my doctoral studies. His ability to reduce complex insights to their essence enabled me to remain clear-eyed and with a vision always focused on the destination. This was central to my sustained motivation through the arduous journey that is familiar to any doctoral student. I am indebted to my dissertation committee members Professors Subhashish Samaddar and Denish Shah for their generous time, guidance, and collaboration.

I am also very much indebted to Christian Loupeda and the other staff at Grameen Foundation for sharing the data for my research. I am indebted to the outstanding faculty and staff at J. Mack Robinson College of Business at Georgia State University including Jorge Vallejos, Dr. Louis Grabowski, Ashley Davis, Stephanie Urbas-Black, and Dr. Karen Loch. I am a much better scholar because of the academic standards they represent and the dedication with which they shared their precious time. I also owe special gratitude to my brilliant classmates and friends of the DBA class of 2020 for supporting and nudging throughout the time we were in the trenches of doctoral studies. 


\section{TABLE OF CONTENTS}

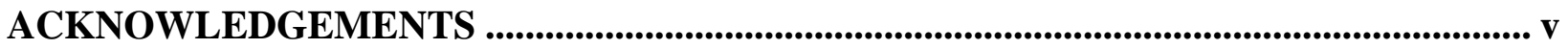

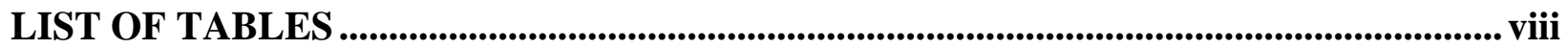

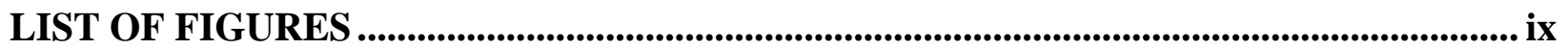

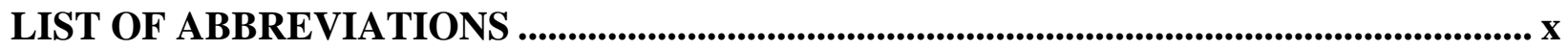

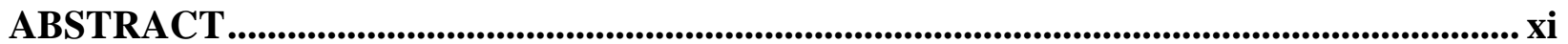

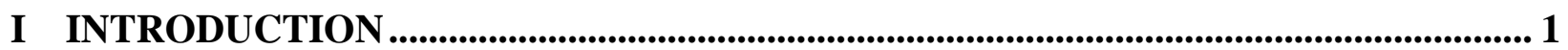

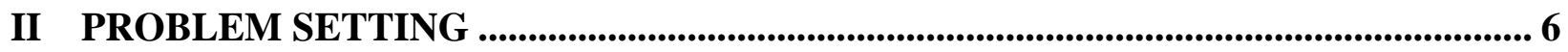

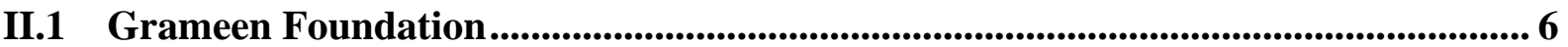

II.2 Innovation in Microfinance..........................................................................................8 8

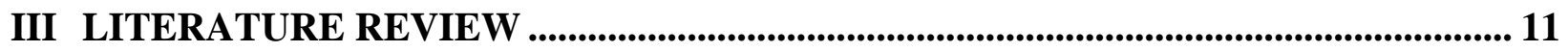

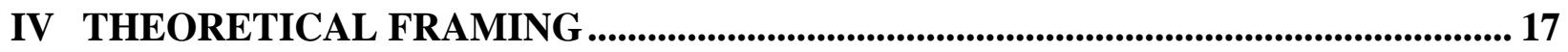

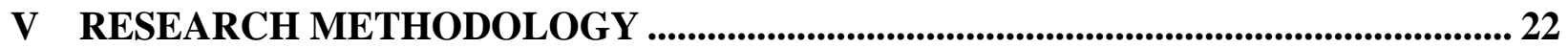

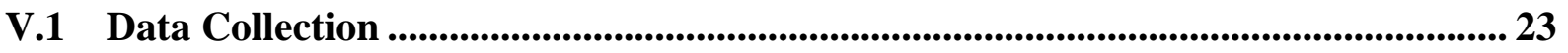

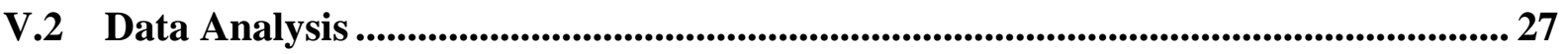

V.3 Inter-coder Reliability and External Validity ................................................................. 29

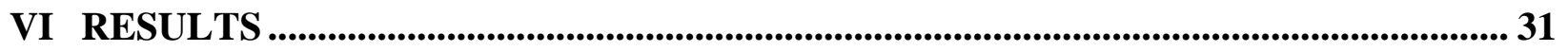

VI.1 Innovation Program I: Agriculture Finance (AF) ...................................................... 32

VI.2 Innovation Program II: Health Finance (HF) ....................................................... 52

VI.3 Innovation Program III: Digital Finance (DF) ................................................ 64

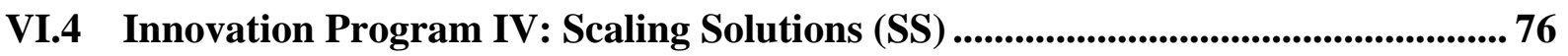

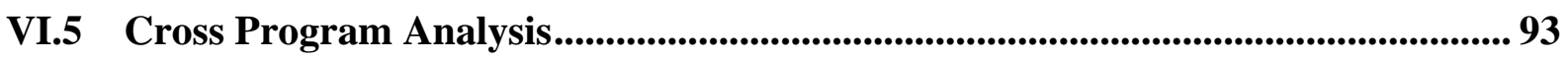

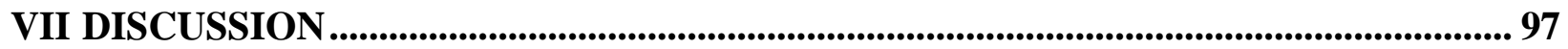

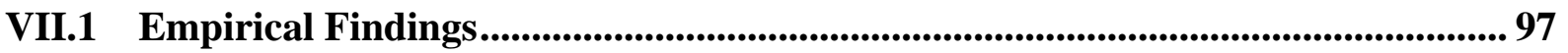


VII.2 Theoretical Advances................................................................................................................. 98

VII.3 Practical Insights ................................................................................................................. 99

VII.4 Limitations and Future Research ............................................................................. 101

APPENDICES .............................................................................................................................................. 103

REFERENCES.......................................................................................................................................... 109

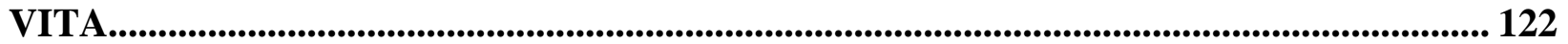




\section{LIST OF TABLES}

Table 1: Research Design Adapted from (Mathiassen, 2017)................................................ 4

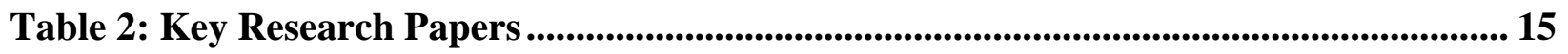

Table 3: Core Concepts of Dynamic Capability Theory .................................................... 19

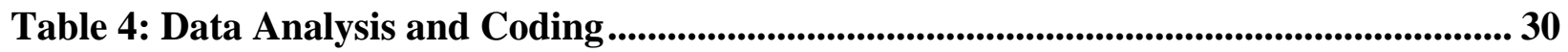

Table 5: Summary of Agriculture Finance (AG) Innovations (2009 - 2019) ...................... 49

Table 6: Summary of Health Finance (HF) Innovations (2009 - 2019) ................................. 62

Table 7: Summary of Digital Finance (DF) Innovations $(2009$ - 2019) ................................ 73

Table 8: Summary of Scaling Solutions (SS) Innovations (2009 - 2019) .............................. 91

Table 9: Cross Program Analysis....................................................................................................... 95 


\section{LIST OF FIGURES}

Figure 1: A Simplified Microfinance Institution Structure ..........................................................8 8

Figure 2: Dynamic Capability Model...................................................................................... 21

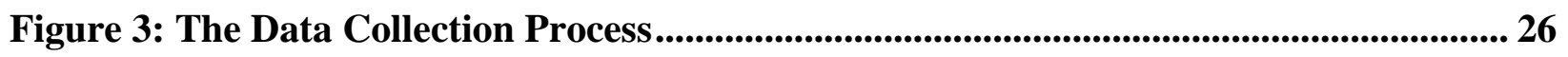

Figure 4: Grameen's Agriculture Finance Portfolio ....................................................... 33

Figure 5: Example of SMS Message sent via CKW to a Client ........................................... 35

Figure 6: Timeline of Agriculture Finance (AF) Innovations.............................................. 36

Figure 7: Timeline of Health Finance (HF) Innovations .....................................................53

Figure 8: Timeline of Digital Finance (DF) Innovations ................................................... 65

Figure 9: Timeline of Scaling Solutions (SS) ................................................................................... 77

Figure 10: Grameen Foundation Impact Investments: Growth Guarantee Program .......... 85 


\section{LIST OF ABBREVIATIONS}

$\mathrm{AF}$

ARET

BwB

CAN

CKW

$\mathrm{Ca}$

$\mathrm{Cp}$

$\mathrm{Cf}$

DCT

DF

DFDP

DFS

GLEAP

GAP

$\mathrm{HF}$

IP

MASS

MF

MFI

NGO

PPI

SHG

SIP

SS

TVIN
Agriculture Finance

Agricultural Risk Evaluation Tool

Bankers without Borders

Community Agent Network

Community Knowledge Worker

Contribution to Area of Concern

Contribution to Practice

Contribution to the Framework

Dynamic Capabilities Theory

Digital Finance

Digital Farm Development Plan

Digital Financial Services

Grameen Learning Program

Good Agricultural Practices

Health Finance

Innovation Program

Maa Aur Shishu Swasthya

Microfinance

Microfinance Institution

Non-government Organization

Progress out of Poverty Index

Self Help Group

Solutions Innovation Process

Scaling Solutions

Transferrable Valuable Imitable Non Substitutable 


\begin{abstract}
Dynamic Capabilities in Microfinance Innovation: A Case Study of The Grameen Foundation

by

Sarah Elizabeth Kayongo
\end{abstract}

May 2020

Chair: Lars Mathiassen

Major Academic Unit: Executive Doctorate in Business

The purpose of this research is to understand how microfinance organizations innovate their products, services, and processes to improve financial inclusion. The research approach used is a retrospective, longitudinal, qualitative case study (Yin, 2014) of how Grameen Foundation, a global non-government organization that partners with various microfinance institutions to provide micro loans, savings, and other financial and professional services innovated. Applying Dynamic Capability Theory (Teece, 1997, 2012 \& 2014) highlighted the unique ways in which Grameen Foundation innovated its products, services, and processes through the three concepts of (1) sensing, (2) seizing, and (3) transforming. We conducted a total of twelve semi-structured interviews with staff and supplemented the interviews with publicly available materials, impact reports, press releases, trade journal articles, and website information. Our findings provide a detailed empirical process account of how Grameen Foundation has consistently been a leader at creating financial linkages through innovating its various programs and the activities within those programs over a ten-year period $2009-2019$. We found the usefulness of Dynamic Capabilities Theory concepts of sensing, seizing and transforming applicable to studies of innovation in microfinance in the non-government sector; however, our 
analysis revealed elements of the theory's core concepts that were not directly applicable. For instance, rather than create Valuable Rare Imperfectly Imitable and Non-substitutable resources, Grameen's philosophy of creating open-sourced market-based solutions that they shared with industry resulted in "Valuable," "Rare," "Diffusible," and "Non-substitutable" resources that were "transferrable" and "imitable", hence we concluded that in the context of innovating in non-government microfinance organizations, this concept translated into Transferrable, Valuable, Imitable and Non-substitutable or "TVIN" resources. We offer a resource guide to microfinance institutions, non-government organizations, and governments of five insights that characterized how Grameen Foundation innovated its products services and processes to improve financial inclusion based on: 1) Sensing country-specific needs; 2) Seizing opportunities to use existing technology; 3) Funding projects that drove innovation overtime and creating financial linkages through multi-sectorial partnerships; 4) Adopting a business model that enabled innovation transfer to attain transformative scale; and 5) Strengthening the internal capabilities of how performance was measured, monitored and evaluated for program outputs in order to sustain the scaling of outcomes. Single case studies tend to suffer from limited generalizability, but details of this study will benefit microfinance practitioners in assessing the transferability of our findings to other contexts (Lincoln and Guba, 1985). We emphasize that in complex and everchanging economic environments, it's increasingly harder to predict the effects that unforeseeable circumstances such as health pandemics would have on global financial markets. We recognize that such changes are likely to produce different outcomes for innovation in microfinance organizations and their beneficiaries. Future studies will benefit from applying experimental design methods and theories that focus on innovation with inbuilt resiliency and capabilities to withstand such extreme but unforeseeable circumstances. Still, we provided a 
detailed empirical analysis of how a global microfinancing organization consistently innovated its products, services, and processes through four programs and twenty activities overtime, and across countries at an in-depth level that few studies have done. Lastly, we have demonstrated that Dynamic Capabilities Theory is very adaptable to studies of innovation in microfinance.

INDEX WORDS: Microfinance, Innovation, Dynamic Capabilities, Grameen Foundation 


\section{INTRODUCTION}

The World Bank defines financial inclusion as "the availability and equality of opportunities to access financial services ${ }^{I}$." When examining the drivers and outcomes of economic activities, studies clearly show that livelihoods improve when businesses and individuals have access to affordable financial products and services that meet their needs through transactions, payments, savings, loans, and insurance (Yunus, 1999; Banerjee, Duflo, Glennerster \& Kinnan, 2009). The World Bank considers financial inclusion a key enabler for seven of the seventeen sustainable development goals aimed at reducing extreme poverty. The Global Findex database, housed by the World Bank, has become a benchmark for scholars and development practitioners in their global efforts to promote financial inclusion. Global Findex data are used to track progress toward the World Bank goal of universal financial access by 2020 and the United Nations sustainable development goals (Demirgüç, Asli, Klapper, Singer, Ansar $\&$ Hess, 2018). Many studies have addressed the lack of financial inclusion and suggested it can be ${ }^{2}$ improved through innovative interventions such as mobile payments, blockchain, biometric data, crowd funding, and microfinance, to mention but a few. However, we lack knowledge about how such innovations may be implemented and managed. To address this gap, this study looks at the important question of how innovation in microfinance organizations may improve financial inclusion.

Microfinance (MF) has evolved as an economic development approach that offers a means for reaching low-income women and men who lack access to formal financial services (Ledgerwood, 1998; Ledgerwood, Earne \& Nelson, 2013). More than 150 million people in lowincome countries have received small loans without collateral over the past three decades

${ }^{1}$ www.worldbank.org/financialinclusion

${ }^{2}$ www.globalgiving.org 
(Armendariz \& Morduch, 2010). Beyond providing microloans for small businesses, microfinance institutions (MFIs) offer a variety of financial services and products that range from insurance, payment services, savings mechanisms and small loans for housing, education, consumption, health financing, agricultural loans (Collins, Morduch, Rutherford \& Ruthven, 2009). Despite its success, the latest ${ }^{3}$ Findex data reported that close to one-third of adults, about 2 billion people worldwide are still unbanked or lack access to formal financial services (Findex, 2018); moreover, half of the unbanked people live in rural areas. At the same time, delivering financial services to rural clients comes with its challenges to providing organizations. Whereas some success stories exist in countries like Bolivia with BancoSol (Navajas, Conning \& Gonzalez-Vega, 2003) and Bangladesh with the Grameen Bank (Yunus, 2004), they do not provide detailed accounts of how the successes were developed or on how differences in scale varied from one context to another. As such, knowing how to create innovative breakthroughs in delivering financial products, services, and processes to marginalized rural populations remains an important challenge facing the microfinance industry today (Frederick, Matthaus \& Pischke, 2009).

Unfortunately, our limited understanding of how MFIs innovate their products, services, and processes denies us the ability to accurately identify its direct impact on improving financial inclusion. Addressing this knowledge gap, this study examines the Grameen Foundation, a USA based non-profit organization that works to leverage and constantly develop the Grameen Bank microfinancing model around the world by partnering with various MFIs to provide micro-loans and other financial and professional services in hard-to-reach areas. Accordingly, we used a single case study approach to understand how Grameen Foundation innovated their products,

${ }^{3}$ www.globalfindex.worldbank.org 
services, and processes to improve financial inclusion over time. We approached the study through a retrospective, longitudinal, qualitative case study (Yin, 2014) based on Dynamic Capability Theory (DCT), (Teece, 1997, $2012 \&$ 2014). Anchoring the study in this theory allowed us to highlight the unique ways in which Grameen Foundation innovated its products, services, and processes through the three core concepts of (1) sensing (identifying business opportunities and threats), (2) seizing (making timely and business-oriented decisions), and (3) transforming (continuously improving and shaping the business environment and resource base) (Barreto 2010; Peteraf et al. 2013; Teece 2014) in response to changes in the industry and to sustain its competitive advantage over time.

As such, this research can help practitioners of MFIs infuse innovation in their design, implementation and transformation of products, services, and processes by providing a detailed empirical account of how Grameen Foundation innovated its approach to microfinancing over a ten-year period (2009-2019) and by advancing theory of MF innovation based on Dynamic Capabilities Theory. In summary, this dissertation follows the style composition (Mathiassen et al., 2012; Mathiassen, 2017) summarized in Table 1, below. The different elements of this research design will be motivated, described, and further elaborated in the subsequent sections. 
Table 1: Research Design Adapted from (Mathiassen, 2017)

\begin{tabular}{|c|c|c|}
\hline Component & Definition & Details \\
\hline $\mathrm{P}$ & $\begin{array}{l}\text { The problem setting } \\
\text { represents people's concerns } \\
\text { in a real-world problematic } \\
\text { situation. }\end{array}$ & $\begin{array}{l}\text { Delivering MF products and services to rural } \\
\text { clients comes with its challenges for the providing } \\
\text { organizations as well as the clients (Frederick, L., } \\
\text { et al., 2009). } \\
\text { Creating innovative breakthroughs in delivering } \\
\text { MF products and services to marginalized rural } \\
\text { populations is one of the greatest challenges } \\
\text { facing the MF industry. (Frederick, L., et al., } \\
\text { 2009). } \\
\text { The lack of an industry-wide model of delivering } \\
\text { MF to rural areas presents an opportunity to } \\
\text { examine existing innovative delivery models and } \\
\text { contribute to improving financial inclusion. }\end{array}$ \\
\hline A & $\begin{array}{l}\text { The area of concern } \\
\text { represents a body of } \\
\text { knowledge within the } \\
\text { literature that relates to the } \\
\text { problem setting. }\end{array}$ & Innovation in Microfinance \\
\hline $\mathrm{F}$ & $\begin{array}{l}\text { The conceptual framing } \\
\text { helps to structure the } \\
\text { analysis of data to answer } \\
\text { the research question. FA } \\
\text { draws on concepts from the } \\
\text { areas of concern, whereas FI } \\
\text { is independent of area of } \\
\text { concern. }\end{array}$ & $\begin{array}{l}\text { Dynamic Capability Theory as an organizational } \\
\text { process framework to examine how scaling is } \\
\text { achieved through innovation at the Grameen } \\
\text { Foundation. }\end{array}$ \\
\hline M & $\begin{array}{l}\text { The adopted methods of } \\
\text { empirical inquiry. }\end{array}$ & $\begin{array}{l}\text { Retrospective, longitudinal qualitative case study } \\
\text { of the Grameen Foundation's innovation of } \\
\text { microfinancing between } 2009-2019\end{array}$ \\
\hline RQ & $\begin{array}{l}\text { The research question relates } \\
\text { to the problem setting; it } \\
\text { opens the research into the } \\
\text { area of concern and helps } \\
\text { ensure the research design is } \\
\text { coherent and consistent. }\end{array}$ & $\begin{array}{l}\text { How can MFIs innovate their products, services } \\
\text { and processes to improve financial inclusion? }\end{array}$ \\
\hline $\mathrm{C}$ & $\begin{array}{l}\text { The contributions to the } \\
\text { problem setting and area of }\end{array}$ & $\begin{array}{l}\text { Cp: Practical insights for how MFIs can innovate } \\
\text { to improve financial inclusion. }\end{array}$ \\
\hline
\end{tabular}




\begin{tabular}{|l|l|l|}
\hline & $\begin{array}{l}\text { concern and possibly to } \\
\text { conceptual framework and } \\
\text { method. }\end{array}$ & $\begin{array}{l}\text { Ca: Detailed empirical account of how Grameen } \\
\text { Foundation innovated its approach to } \\
\text { microfinancing over a 10-year period. } \\
\text { Cf: Advancing theory of MFI innovations based } \\
\text { on Dynamic Capability Theory. }\end{array}$ \\
\hline
\end{tabular}




\section{PROBLEM SETTING}

\section{II.1 Grameen Foundation}

Inspired by the work of Nobel Laureate Muhammad Yunus, founder of the Grameen

\section{Bank and a recognized global leader in the fight against poverty, Grameen Foundation was}

founded in $1997^{4}$. Yunus was a founding member of the board of directors and today serves as member emeritus. Grameen Foundation works with a network of MFIs in Africa, the Americas, Asia, and the Middle East to provide microfinance to the world's most vulnerable communities. Grameen Foundation has provided its partner organizations with financing and technical support. Within the first decade of operation, the 52-member network had provided microfinance services to 10.9 million people, and today that number has continued to grow.

Overtime, Grameen Foundation broadened its approach to tackle multiple dimensions of the complex problems of poverty (as illustrated in Figure 1) by identifying solutions that build on the strengths of the poor, putting technology to work, strengthening resilience and food security, increasing incomes, enhancing health, and building financial security. In a 2016 merger, Grameen Foundation acquired Freedom from Hunger another global nonprofit. Founded in 1946 under the name of Meals for Millions, throughout its 70 years, Freedom from Hunger had been at the fore front of tackling the root causes of poverty through programs focused on ending hunger among the world's poor. The integration of the two organizations brought together Grameen Foundation's expertise in digital innovation to end poverty and Freedom from Hunger's focus on providing the world's poorest women with self-help tools to reduce hunger and poverty. Today, Grameen Foundation continues to expand and strengthen its programs, partnerships, and geographic reach to enable the poor, especially women, to create a world without poverty and

\footnotetext{
${ }^{4}$ www.grameenfoundation.org
} 
hunger. The Grameen Village Banking Model has been adopted with different variations by MFIs worldwide (Yunus, 1998).

It is important to note the role different stakeholders play in the organization of MF delivery. Usually, there are larger donors or investors such as banks, private equity firms, nongovernment organizations (NGOs), or social enterprises with pools of funds to loan at low interest rates in very small amounts to groups of poor people. They work with MFIs in developing countries to disburse the funds by building the capacity of MFIs directly through subsidies or indirectly through training, building linkages with other institutions like mobile phone providers, and determining product and service delivery mechanisms. MFIs then reach out to the end-users, clients, or borrowers. The most commonly used lending mechanism is to a selfhelp group (SHG) of 15-25 members ${ }^{5}$, usually women, but individual loans exist too. Group lending comes with a "joint liability" condition to foster a sense of responsibility among members and to ensure collective loan repayment. Group lending has been proven to better repayment and monitoring (Banerjee et al. 1994; Beasley \& Coati, 1995). Group lending succeeds by utilizing peer network and local knowledge of potential group members to assess risks and by inducing homogeneity in the group through "positive associate matching" (Ghatak, 2000). Where it is hard to determine positive associate matching, other MF scholars have argued that high-risk borrowers can compensate low-risk ones (Armendáriz \& Gollier, 2000). This delivery structure of MF is illustrated in Figure 1 below. In this study, our focus will be on Grameen Foundation, a non-government organization that leverages and develops the delivery of MF products and services to the poor through a global network of local MFIs.

${ }^{5}$ www.finca.org 
Figure 1: A Simplified Microfinance Institution Structure

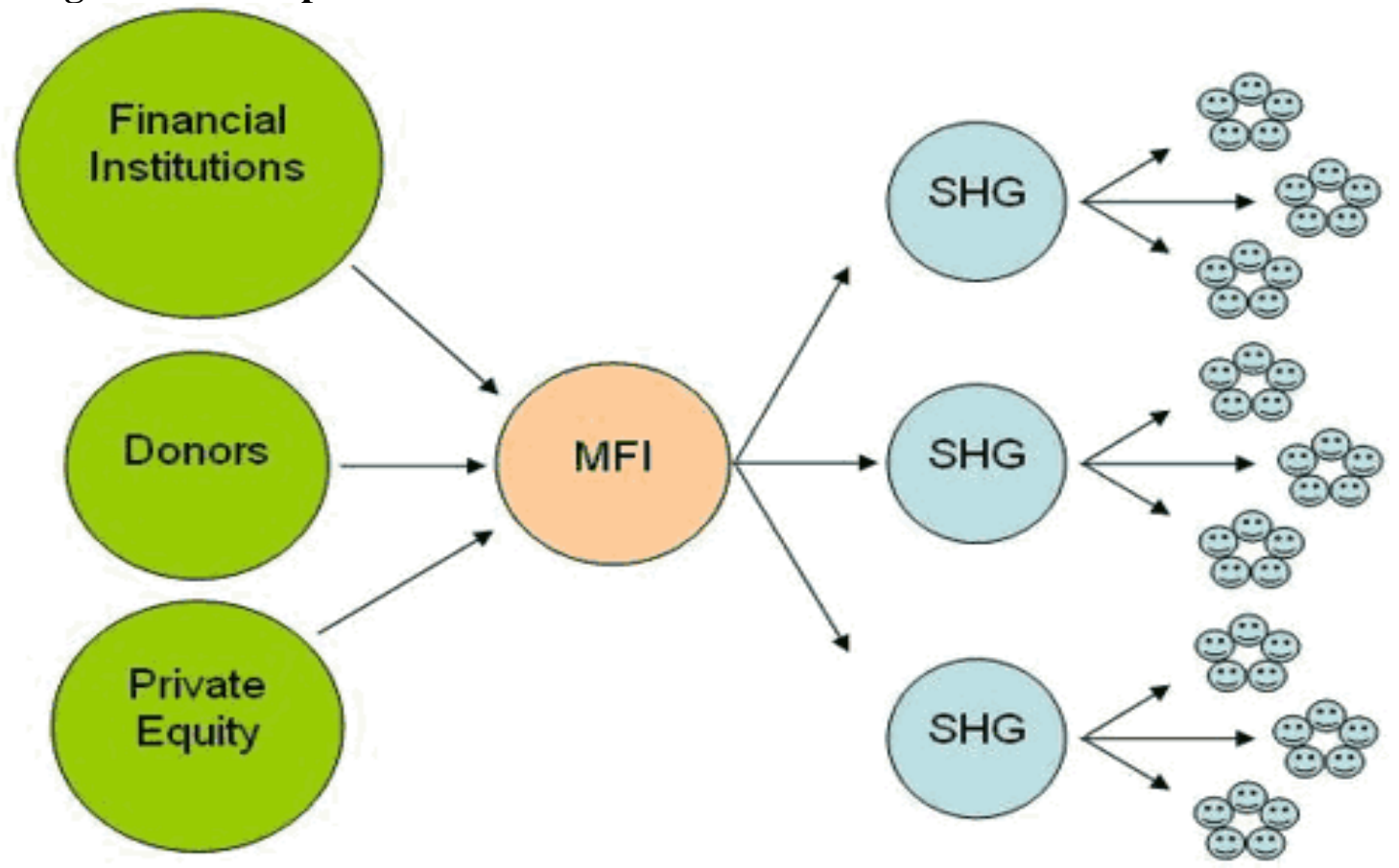

Source: Microfinance Institution structure adapted from the Grameen village-lending model Bangladesh, 2009. *MFI: Microfinance Institution. *SHG: Self Help Group.

\section{II.2 Innovation in Microfinance}

An innovation is the first time use of an invention for commercial purposes (Schumpeter, 1934). According to Schumpeter, innovation does not mean invention; whereas invention is a new useful product or process not yet brought into commercial use, innovation refers to the commercial application of new technologies, materials, methods, and sources of energy.

Diffusion of an innovation explains how an idea or a product offering gains popularity and spreads over time through social systems and culture (Rogers, 2003). Others have extended the Schumpeterian definition to include a process that turns an idea into value for the customer and results in sustainable profit for the enterprise (Carlson \& Wilmot, 2006). Consequently, innovations are taken up in new places and new applications throughout the economy; they translate into a process of developing and implementing any new product, business process, or 
idea, or into the modification and recombination of existing ones by an individual or another unit of adoption (Rothaermel, 2013; Van de Ven, Polley, Garud \&Venkataraman, 1999).

Innovation in MF is reported to occur in waves, and the first wave included five categories (Mersland \& Strom, 2010). First, the targeting of poor customers as a new market segment upon which the primary business model rests. Second, the targeting of women in an organized group is in line with the United Nation's sustainable development goal (SDG) number five of achieving gender equality and empowering of all women ${ }^{6}$. Third, new lending technologies; in the absence of collateral, the MF industry has developed loan types to meet this problem. The loan may combine characteristics such as a group loan, a small loan, and a loan given on short maturity. The basic characteristic of the group lending arrangement is, in most cases, that a loan is given to an individual, but the whole group is responsible for its repayment (Armendáriz \& Morduch, 2005). The joint liability condition of the group loan and social capital acts as a substitute for collateral (Tirole, 2006). Fourth, new organizational solutions; for MF initiatives to work, the community to which group members belong is usually very close, such as the self-help groups in a village setting. The community-based monitoring system ensures that customers are accountable. Lastly, new innovative sources of funding, for MF providers to reach the poorest segments, they need continued subsidies (Morduch, 2000). MF constitutes an innovation in its sourcing of funds, and therefore plays a vital role in mobilizing and allocating international capital for investment purposes in developing countries. Currently, more than one hundred international microfinance investment vehicles invest in MF initiatives worldwide (www.mixmarket.org), offering equity, loans, bonds, collateralized debt obligations or

\footnotetext{
${ }^{6}$ www.un.org
} 
securitization (Reille et al., 2009). A good example of such an investment vehicle is $\mathrm{Kiva}^{7}$, which acts as a personalized online lending platform across borders. Kiva, a San Francisco based nonprofit founded in 2005, applies crowd funding to offer loans as small as $\$ 25$ from individual lenders to poor persons and small businesses in developing countries. Kiva's approach has enabled 3.2 million people in 78 countries access to a total of $\$ 1.30$ billion in loans, with excellent repayment rates of $96.9 \%^{8}$.

While the first wave of innovation in MF took the form of simple applications in products, services, and delivery models and has taken root at the bottom of a market in an almost disruptive way (Christensen, $2005 \& 2010$ ), MF scholars argue that for it to have sustainable impact in an ever-changing competitive environment, a second wave of innovation may be required (Murdock, 2000; Strom \& Mersland 2010; Frederick et. all, 2009). However, it remains to be seen if the second wave of innovation relentlessly moves upmarket and eventually displaces established competitors and the extent of their diffusion to scale compared to the first wave of innovation (Rosenberg, 1994). For the purpose of this dissertation, we adapt the Schumpeterian definition in the first wave of innovation in MF and how it relates to the diffusion of products, services, and processes to scale as proposed above (Carlson \& Wilmot, 2006; Rogers, 2003; Van de Ven et al., 1999; Rothaermel, 2013).

${ }^{7}$ www.kiva.org

${ }^{8}$ Ibid 


\section{LITERATURE REVIEW}

Microfinance has proved to be an effective intervention in the fight against poverty since it offers a means for reaching rural clients who are left out of the formal financial sector. Various studies have indicated that more than 150 million people in low-income countries have received small loans without collateral over the past three decades (Armendariz, et.al; Lakshmi, 2010). MFIs have been able to extend such substantial sums of unsecured credit because they have received subsidies that defray as much as $50 \%$ of their operational costs and risks (Morduch, 2000). Various studies show the effectiveness of MF as a poverty-fighting tool with direct social and economic impact. For example, household surveys conducted among MF recipients in India showed an improvement in their economic activities and increased profitability (Banerjee, Duflo, Glennerster \& Kinnan, 2009). Other extensive studies conducted in Bangladesh, South Africa, and the Philippines indicate increased consumption of household goods, and schooling at household levels (Chandler, 1998; Karlan \& Zinman 2009). These studies demonstrate that once given the opportunity, not only do clients expand their businesses and increase their incomes, but their high repayment rates also demonstrate that the poor can transform their own lives. As such, MF initiatives have been widely adopted for their demonstrable and sustainable impact among the poor (Morduch, 1999 \& 2014; Coleman \& Pitt, 1999; Morduch \& Roodman, 2009).

While delivery models may differ depending on the context, MF as a poverty fighting intervention is not new ${ }^{9}$; its successful adoption and global reach have accelerated greatly since the 1970s. In several European countries, MF evolved from informal beginnings during the eighteenth and nineteenth centuries as a type of banking for the poor, juxtaposed to the

${ }^{9}$ Seibel, Hans Dieter (2005): Does History Matter? The Old and the New World of Microfinance in Europe and Asia, Working Paper, No. 2005,10, Universität zu Köln, Arbeitsstelle für Entwicklungsländerforschung (AEF), Köln 
commercial and private banking sector (Seibel, 2005). In the USA and Canada, peer group lending still exits to encourage economic activity in low-income communities (Conlin, 1999). Also, traditional informal financial systems like the Rotating Savings and Credit Associations with household participation above $50 \%$ is not uncommon especially among women farming groups in African and Asian villages (Bauman, 1995). These schemes foster regular meetings among members where they gather with a purpose of pooling their savings and rotating the money among themselves as loans either monthly or biweekly. The groups normally consist of 10 to 30 members, organized by the members either collectively, or by one or a few of the key members. Loans are small, short term, and backed by informal or group collateral. International NGOs like CARE International have modeled their MF programs, the Village Savings and Loan Associations ${ }^{10}$ after the traditional Rotating Savings and Credit Associations (Adams \& Fitchett, 1992). While the main focus of the first lending programs was to prove that the rural smallholder farmers were creditworthy, the successful transition of former MFIs to formal banking institutions such as the Grameen Bank in Bangladesh, and later ACCION to BancoSol in Bolivia, not only demonstrated it, but also proved that this model could be financially sustainable (Kulik $\&$ Molinari, 2004). Therefore, it was replicated throughout the developing world from Asia to Latin America and Africa.

Indubitably, the success of MF has been well documented but given the growing lack of financial access especially in rural areas, several studies suggest that there is room for improvement (Helms, 2006; Mersland, 2007; Frederick, et al., 2009). A recent World Bank report on Global Financial Inclusion and Fintech inclusion (Findex, 2018), found that close to 2 billion adults globally remain unbanked. When choosing their delivery model, MFIs must

${ }^{10}$ www.CARE.org 
grapple with overcoming the challenges that come with reaching the unbanked in remote and sparsely populated areas for a number of reasons.

First, there are operational costs associated with delivering small loans at frequent intervals to rural populations. MF is an information-intensive activity; the volume of transactions is very small, whereas the fixed cost of transactions is very high, resulting in high transaction costs and low profitability (Das, Srinivasan \& Kodamarty, 2010; Khanvilkar, 2016). MFIs have a double bottom line mission of serving the rural poor while making some profit from low interest rates. In the recent past, the industry has come under serious criticism for being driven by profit and having drifted from their original mission of serving the poor following reported incidents of unscrupulous practices among a few MFIs in Bangladesh where the government had to intervene with regulation (Bateman, 2010). However, findings from another study that examined a wide data sample covering 405 MFIs in 73 countries from www.mixmarket.org found that far from being driven by high profits, the industry struggles with high costs and low earnings. Furthermore, the study could not confirm the claims on "mission drift" (Mersland \& Strom, 2013). MFIs have to carefully manage the risk-return relationship by minimizing operational costs and achieving profitability through high rates of process automation while maximizing outreach (Wydick, 1999; Armendariz, 1999 \& 2000; Anderson et al., 2002; Chowdhury, 2005 \& 2009; Mersland, 2010; Toindepi, 2014).

Second, rising competition and lack of centralized information systems, experimentation, information technology adoption with limited capacity and infrastructure to scale for loan clients among NGOs (Moturi \& Mbiwa, 2015), have given rise to asymmetric information problems in saturated markets. As an example, a study in Uganda, one of Africa's top MF markets, observed that rising competition did not lead to an increase in client dropout rates, but it induced a decline 
in repayment performance and savings deposited with the incumbent, suggesting rising multiple loan-taking by clients due to lack of information sharing (McIntosh \& Wydick, 2005; Wright \& Ripley, 2003). Information asymmetries also arose from identification and security challenges as MF beneficiaries usually have limited official identification, making it extremely difficult for institutions to effectively offer financial products that would fulfill their obligations of outreach and profitability (Cull et al., 2007; Khanvilkar, 2016).

Third, few government policies exist in middle to low-income countries that foster an environment of innovation among MFIs (Navajas, et al., 2003; Frederick, et al., 2009; Adeel and Nett, 2013; Mersland \& Strøm 2009). In juxtaposition to Uganda, studies in Bolivia, one of the most competitive and rapidly evolving MF markets, report the successful leveraging of competition and a consolidated or group loan approach that led to rapid scale in the 1990s. In La Paz, the population of borrowers reached by Bolivian lenders exploded as diverse MF providers entered to supply the market (Baydas, et al., 1997; Christen, 2001; Mosley, 1996; Poyo \& Young; Navajas et al., 1999; Robinson, 2001). Two notable lenders, both having started as notfor-profit NGOs and later transformed into profitable regulated financial intermediaries, fueled this success: Banco Solidario (BancoSol) and Caja Los Andes (Los Andes). Nevertheless, examples like Bolivia are case by case and may not be generalizable in the context of MFIs elsewhere.

Still, our limited understanding of how MF organizations innovate their products, services, and processes denies us the ability to accurately identify their impact to improving financial inclusion. Our review of over 100 peer-reviewed articles and books on MF yielded several of the themes outlined above: impact of MF on the poor, high operating cost and low profitability involved in the delivery of MFI, and difficulties of measuring outcome due to lack 
of centralized information systems including inconsistent lending technologies, and information asymmetries resulting from competition. Each of these themes, along with sample citations, is summarized in Table 2. Extant literature is dominated by variance models with no, or very limited in-depth empirical analyses of how NGOs innovated their MF solutions over time. Moreover, there was an over emphasis on commercially oriented MFIs. The commercial leaning of studies tends to measure the efficiencies analysis of MF by applying Stochastic frontier models such as the Ponzar-Rosse revenue tests in static and dynamic models (Assefa, Hermes \& Meesters, 2013; Mersland, et. al, 2012; Singh, et. al., 2013; Kipesha, 2012; Abete, Borzaga \& Getnet, 2014).

Table 2: Key Research Papers

Key Topics Publications

\begin{tabular}{|l|l|}
\hline $\begin{array}{l}\text { Social and economic } \\
\text { impact }\end{array}$ & $\begin{array}{l}\text { Morduch, 1999 \& 2014; Coleman, 1999; Pitt \& Khandker, 1998; } \\
\text { Morduch \& Roodman, 2009; Karlan \& Zinman, 2010; Yunus, 1998; } \\
\text { Banerjee, Duflo, Glennerster \& Kinnan, 2009. }\end{array}$ \\
\hline High operating costs & $\begin{array}{l}\text { Das, 2010 \& 2015; Khandikul \& Wydick, 1999; Armendariz, } 1999 \text { \& } \\
\text { 2000; Anderson, et al., 2002; Chowdhury, 2005 \& 2009; Mersland, } \\
\text { 2010; Toindepi, 2014. }\end{array}$ \\
\hline $\begin{array}{l}\text { Information } \\
\text { asymmetries and } \\
\text { competition }\end{array}$ & $\begin{array}{l}\text { McIntosh \& Wydick, 2005; Cull et al., 2007; Mersland \& Strom, 2009; } \\
\text { Siegel, 2012; Ghosh \& Tassel, 2013. }\end{array}$ \\
\hline $\begin{array}{l}\text { Lending technologies } \\
\text { and innovation }\end{array}$ & $\begin{array}{l}\text { Navajas, Conning, \& Gonzalez-Vega, 2003; Frederick, Matthaus- } \\
\text { Maier, Pischke, 2009; Adeel \& Nett, 2013; Moturi \& Mbiwa, 2015; } \\
\text { Christensen, 2005 \& 2010; Schumpeter, 1934; Rogers, 2003. }\end{array}$ \\
\hline
\end{tabular}

Organizational change scholars have long argued that in an ever-changing environment, firms have to "continuously innovate to stay competitive," and, "firms must manage innovation processes in increasingly complex situations with growing numbers of diverse actors" (Van de 
Ven, 1986 \&1999; Roberts, 1998). More recent studies on innovation in MF have suggested that to achieve "scalability and wider impact as well as greater efficiency," there is a need to transition to new financial instruments through the use of "impact bonds" (Kamal, 2016); but for such transitions to be successful, it would take the cooperation of policy makers. Whereas we found many studies conducted on the Grameen Bank model including a recent one on Grameen Foundation (Kayongo, Tom \& Mathiassen, 2020), we found no studies that had applied Dynamic Capabilities Theory (Teece, $1997 \& 2014$ ) in a process approach to explain how Grameen Foundation innovated its financial solutions to increase impact.

We sought to fill this gap in knowledge by extending existing theories of innovation to a NGO engaged in MF programs based on DCT (Teece, 1997, 2007 \& 2014). Anchoring the study in DCT allowed us to highlight the unique ways in which the Grameen Foundation innovated its MF products, services, and processes through the lenses of (1) sensing (identifying business opportunities and threats), (2) seizing (making timely and business-oriented decisions), (3) transforming (continuously improving and shaping the business environment and resource base), over a period of ten years from 2009 - 2019. Against that backdrop, we asked the following research question: How can microfinance organizations innovate their products, services, and processes to improve financial inclusion? 


\section{THEORETICAL FRAMING}

We adopted a process model (Markus \& Robey, 1988) to understand and explain how innovation in MF delivery unfolded within Grameen Foundation over time (Van de Ven, 1995). Existing studies on MF have relied on variance models focused on relationships between antecedents and outcomes (Markus, et. al., 1988). That approach might be too restrictive for our purposes because for MFIs to remain competitive in an ever-changing environment, they have to constantly adapt. As an alternative, process models attempt to explain how context shapes the process under study and how the process affects outcomes (Radeke, 2010). As such, process models are concerned with key events in an organization, and how key events, in turn, can be generalized to other contexts (Cho, Mathiassen \& Nilsson, 2008). We applied a process theory, DCT (Teece, 1997, $2007 \& 2014$ ), to help us understand how organizations responded to change and sustained a competitive advantage over time in highly dynamic environments. Using this theory enabled us to answer the research question by examining existing paths and positions at Grameen Foundation, where we sought to understand what factors triggered innovation, and how those new innovations were designed and implemented through an iterative process by which new paths and positions emerged. Lastly, using a longitudinal case study design allowed us to highlight the key program innovations and their activities through a timeline display (2009 2019).

First introduced by Teece, Pisano \& Shuen, 1997; Teece, 2007 \& 2014, DCT helped us understand how organizations responded to environmental change and sustained a competitive position over time. The theory framework includes four sets of concepts as summarized in Table 3., below. The first set of concepts suggests that organizations have existing paths (organizational heritage) and positions (resource bases) that they need to develop further. Such 
development requires strong capabilities that are the subject of the second set of concepts: ordinary capabilities and dynamic capabilities (Peteraf, et al., 2013; Teece, 2014). Ordinary capabilities and their associated best practices are rooted in organizational routines and are essential for an organization to perform and complete operational, administrative, and governing tasks in an efficient manner. In software development, for example, researchers have highlighted the critical role of operational capabilities such as productivity-enhancing processes and tools that maintain organizational performance (Li et al., 2010). Although organizations can acquire ordinary capabilities, they are traditionally far from being fully diffused. Moreover, ordinary capabilities might be sufficient in stable and protected business environments, but they might not support a sustainable competitive position under unpredictable business conditions. Accordingly, researchers posit that in fast-moving environments, organizations need to continuously modify and, if necessary, completely revamp what the organization is doing to maintain a good fit with the ecosystem that the organization occupies (Teece, $2012 \& 2014$ ). Such developments require strong capabilities that are innovatively based and represent the organization's potential to solve problems systematically as business conditions change.

Studies argue that dynamic capabilities can be categorized into three clusters of activities as the third set of concepts: (1) sensing (identifying business opportunities and threats), (2) seizing (making timely and business-oriented decisions), (3) transforming (continuously improving and shaping the business environment and resource base) (Barreto, 2010; Peteraf, et al. 2013; Teece, 2014). Finally, it is essential to note that according to DCT, dynamic capabilities must be performed expertly to help develop valuable, rare, imperfectly imitable, and nonsubstitutable resources (VRIN) (Peteraf, et al., 2013; Teece, 2014). It is the strategic management of capabilities as well as VRIN resources that facilitates the last set of concepts 
(new paths and positions). We seek to advance the theorizing of innovation in MFIs by building

on these concepts of the DCT to guide our empirical investigation.

Table 3: Core Concepts of Dynamic Capability Theory

\begin{tabular}{|c|c|}
\hline Concept & Definition \\
\hline Prior Paths & $\begin{array}{l}\text { Refer to an organization's existing business model or path in relation to how it } \\
\text { creates and delivers MF products, services, and processes to end users and } \\
\text { other stakeholders (Teece, 2014). }\end{array}$ \\
\hline Prior Positions & $\begin{array}{l}\text { Refer to the tangible and intangible resources an organization relies on to } \\
\text { create and deliver MF products and services to end users and other } \\
\text { stakeholders. }\end{array}$ \\
\hline $\begin{array}{l}\text { Ordinary } \\
\text { Capabilities }\end{array}$ & $\begin{array}{l}\text { Refer to capabilities for achieving technical efficiency and doing things right } \\
\text { in an organization's core business function such as programs, finance, } \\
\text { information technology, and administration. }\end{array}$ \\
\hline $\begin{array}{l}\text { Dynamic } \\
\text { Capabilities }\end{array}$ & $\begin{array}{l}\text { Whereas ordinary capabilities are about doing things right, dynamic } \\
\text { capabilities are about doing the right things and at the right time. They tend to } \\
\text { get built, are difficult to imitate, and cannot generally be bought. }\end{array}$ \\
\hline Sensing & $\begin{array}{l}\text { Refer to the identification, development, co-development, and assessment of } \\
\text { technological opportunities in relationship to customer needs (Teece, 2014). } \\
\text { For example, Grameen Foundation sensed that small holder farmers in remote } \\
\text { places needed access to digital financial solutions, agricultural finance, health } \\
\text { finance, financial literacy, technical advice and other information in real time, } \\
\text { but poor connectivity in middle to low income countries posed major } \\
\text { challenges for field agents and small holder farmers to experience shared } \\
\text { knowledge. Grameen Foundation observed that widespread diffusion of } \\
\text { mobile technology in these countries provided opportunities to develop } \\
\text { connectivity. }\end{array}$ \\
\hline Seizing & $\begin{array}{l}\text { Refer to the mobilization of resources: human, financial, and technological to } \\
\text { address needs and opportunities, and to capture value from doing so (Teece, } \\
\text { 2014). Continuing the example from sensing, Grameen Foundation seized in } \\
\text { three ways: Firstly, by designing innovative apps enabled technology used to } \\
\text { collect and analyze data from small holder farmers it in real time. Secondly, by } \\
\text { mobilizing partnerships with value propositions such as: donors, government } \\
\text { agencies, financial institutions, MFIs, agribusiness, NGOs, Fintech companies } \\
\text { and others who provided the funding and the linkages to address small farmers } \\
\text { needs. Thirdly, they trained peer community agent networks that facilitated the } \\
\text { implementation of innovation at scale. These agents advised farmers on the } \\
\text { opportunities for financial products, services and processes, access to markets, } \\
\text { and training through multiple channels such as SMS messages sent directly to }\end{array}$ \\
\hline
\end{tabular}




\begin{tabular}{|c|c|}
\hline & $\begin{array}{l}\text { farmers' mobile phones, radios messages, and by utilizing Grameen's inhouse } \\
\text { e-learning platform, G-Leap. Grameen Foundation exploited its experimental } \\
\text { capability by applying techniques such as Human-Centered Design. }\end{array}$ \\
\hline Transforming & $\begin{array}{l}\text { Refer to the continued configuration, or transformation of a firm's asset base } \\
\text { or existing resources. Transformation and asset reconfiguration depend } \\
\text { critically on top management's ability to recognize key developments or } \\
\text { trends, then delineate a response and lead the firm in its path forward (Adner } \\
\& \text { Helfat, 2003; Helfat \& Peteraf, 2013; Teece, 2014) and to do this } \\
\text { repeatedly, thereby helping to create a sustainable competitive position. } \\
\text { Elaborating the example, Grameen Foundation transformed by continuously } \\
\text { reconfiguring its business model overtime. The SIP approach allowed for } \\
\text { continuous improvement of financial products, services, and processes as they } \\
\text { are assessed and monitored through rapid prototyping, piloting, launching, and } \\
\text { iteration from context to context. Another aspect of transforming in the } \\
\text { business model was the focus on integrated solutions that Grameen } \\
\text { Foundation achieved by creating financial linkages across the other programs } \\
\text { namely agriculture finance, health finance, digital finance. Lastly, Grameen's } \\
\text { ability to diffuse innovative products, services, and processes at scale was } \\
\text { evident in the market-based solutions that they spin-off to other organizations, } \\
\text { NGOs, and even governments such as Taroworks TM, PPI® and Bankers } \\
\text { without Borders. }\end{array}$ \\
\hline VRIN & $\begin{array}{l}\text { Refer to valuable, rare, imperfectly imitable, and non-substitutable resources } \\
\text { that an organization own. The key dynamic capability of VRIN, according to } \\
\text { Teece (2014), is that resources are products of the firm's heritage and past } \\
\text { managerial decisions tend to get in built, are difficult to imitate, and cannot } \\
\text { generally be bought. In the case of an NGO like Grameen Foundation, we will } \\
\text { see what these qualities of innovation are, as compared to VRIN after a closer } \\
\text { analysis of the data. }\end{array}$ \\
\hline New Paths & $\begin{array}{l}\text { Refer to an organization's new business model and how innovation is infused } \\
\text { in the design, implementation, continuous learning and delivery of financial } \\
\text { products, services, and processes to end users and other stakeholders. }\end{array}$ \\
\hline New Position & $\begin{array}{l}\text { Refer to an innovation in the organization's new tangible and intangible } \\
\text { resources. }\end{array}$ \\
\hline
\end{tabular}

Source: Dynamic Capabilities Concepts: Teece, D. J., (2014). The Foundations of Enterprise Performance: Dynamic and Ordinary Capabilities in an (Economic) Theory of Firms. The Academy of Management Perspectives, 28 (4), 328-352 
Figure 2: Dynamic Capability Model

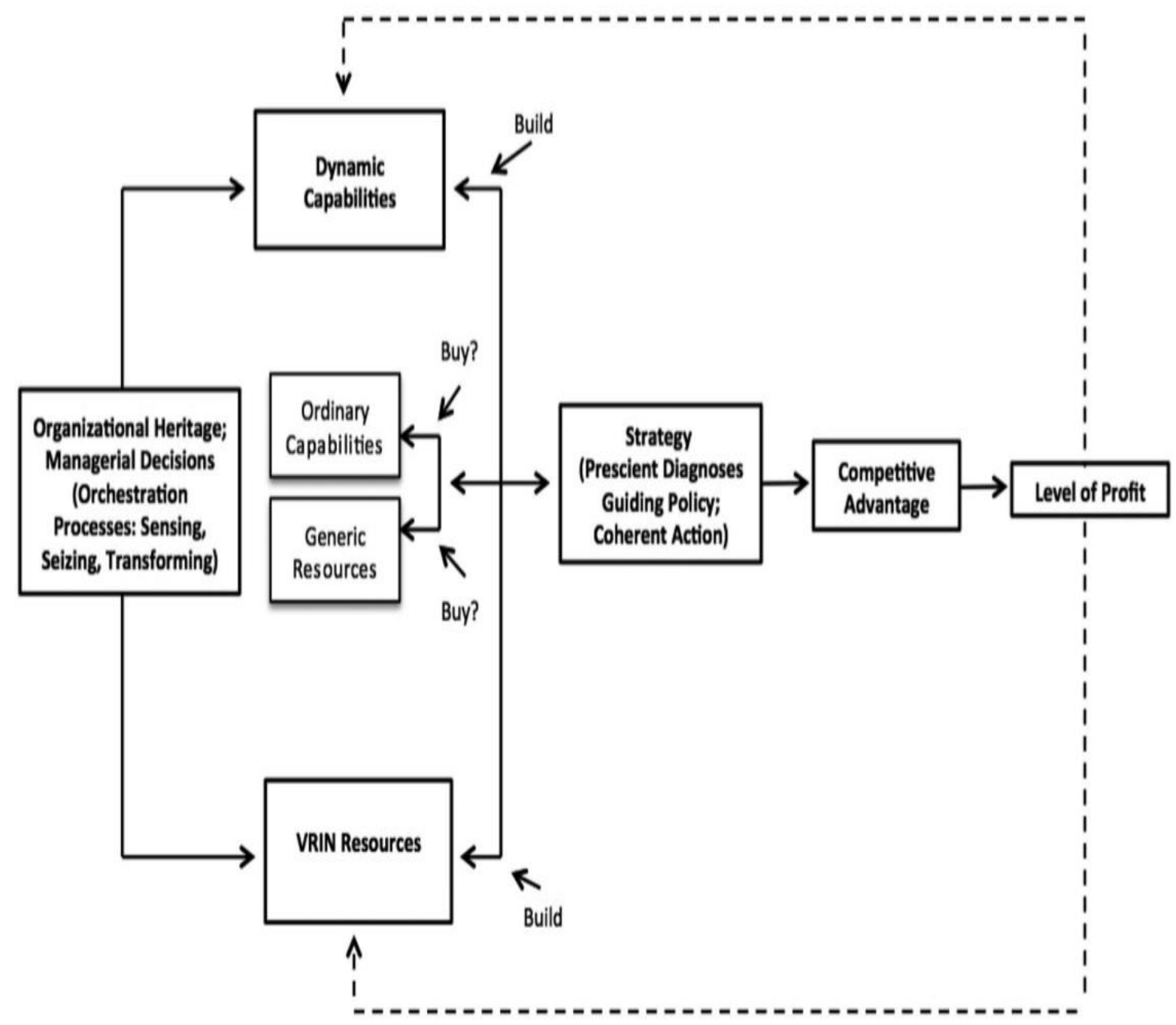

Source: Based on Teece (2014).

*VRIN: Valuable, Rare, Imperfectly Imitable and Non Substitutable. (Teece, 2014). 


\section{RESEARCH METHODOLOGY}

We used the single case study approach but supplemented it in various ways. First, multiple data sources and theory-driven data analysis are key characteristics of case study research (Yin, 2003). We had access to very rich data about innovation by the Grameen Foundation, including published journal articles, interviews, press releases, archival records, website, and complimenting it with information from multiple stakeholders. Grameen Foundation prides itself on being a champion at innovating MF products, services, and processes. In 2018, prior to this study, the researchers (Kayongo and Mathiassen) were engaged with staff at Grameen through interviews and coauthored a paper (Kayongo, Tom \& Mathiassen, 2020) following a multiple case study approach where they compared how Grameen Foundation, CARE and Oxfam organized and orchestrated their MF initiatives based on Contextualist Inquiry (Pettigrew, 1985).

Although traditionally data collected through qualitative methods are expected to emerge from multiple cases before being generalized (Campbell, 1975; Hamilton, 1980; Kemmis, 1980; Yin, 1994), the importance of single case studies is recognized (Markus, 1983; Stake, 1994) especially for studies aimed at theory building (Narasimhan \& Jayaram, 1998) and theory refinement (Hyer, et. al., 1999). In his book on Case Study research, Yin (1994, p.43) stated that single case studies have importance when the intent of the study is either "extending the current understanding of knowledge or falsifying it." The case study method is hence appropriate for validating the applicability of findings of one study in another context as has been applied in the study of microfinance as well as other disciplines like Information Systems (Remenyi \& Quinones, 2000; Littlefield, Morduch \& Hashemi, 2003; Banerjee, et. al., 2015 \& 2014; Samaddar \& Kadiyala, 2005; Ghobadi, Mathiassen \& Rai, 2019). 
We applied DCT (Teece, 2012 \& 2014) to help shape our in-depth analysis of how Grameen Foundation designed, implemented, and delivered innovation analyzed through the lenses of DCT's concepts of sensing, seizing, and transforming (Teece, 2012 \& 2014). To understand how innovation at Grameen changed over time (2009 - 2019), we employed a retrospective longitudinal design to examine change processes that require in-depth and intensive analysis over an extended period (Langley, 1999; MacKay \& Chia, 2013; Yin, 2009).

Since our study was an attempt to adopt the generally well-known Dynamic Capability Theory and adapt it to our analysis of "how" (Yin, 2003 \& 2014) Grameen innovated MF solutions, a case study design seemed to be the best fit for our purposes. Hence our inquiry falls under the category of generalization studies "from empirical to theoretical" (Lee \& Baskerville, 2003).

\section{V.1 Data Collection}

We collected data from staff and external stakeholders of Grameen Foundation using semi-structured interview questions. An example of external stakeholders includes Taroworks ${ }^{\mathrm{TM}}$, Inc. ${ }^{11}$, started by Grameen and is a now a wholly owned subsidiary of Grameen Foundation. TaroWorks ${ }^{\mathrm{TM}}$ is a cloud based software company that improves product and service delivery to the poor by bringing real-time data to any organization in developing countries. Using this approach allowed us to (a) reduce biases resulting from social desirability or using single perspectives (Kistruck, 2015) and to (b) develop a comprehensive empirical account and a framework to explain how Grameen has innovated its MF products, services, and processes. The questionnaire contained fifteen semi-structured questions organized in three distinct parts to capture the study's three theoretical concepts of sensing, seizing, and transforming. Since

${ }^{11}$ www.taroworks.org 
Grameen Foundation merged with Freedom from Hunger and the old Grameen (October 2016 press release, http://www.freedomfromhunger.org), we were keen to establish if the respondents worked with either Freedom from Hunger or the old Grameen. If their response was yes, we asked them follow up questions (see appendix 1. questionnaire) seeking to understand how differently the two organizations innovated, what factors triggered innovation and challenges, success or lessons learned from the integration and the outcomes of the innovation in the form of new paths and positions. To support our interviews, we developed a chronological analysis of how Grameen Foundation had innovated its MF offerings over a considered period of about ten years (2009 - 2019). Triangulation was achieved by complimenting interview data with archival data, reports, Internet information, blogs, and more. Respondents were very open to sharing internal reports in addition to the interviews and published documents. Since approval from the Institutional Review Board was obtained in March 2019, we embarked on data collection in four phases, as described below in Figure 4.

In the first phase from March 2019 - April 2019, we organized an initial insight or handshake meeting at the end of that month between the research team (candidate and advisor) and the Senior Director of Financial Inclusion at Grameen Foundation to frame the study period and identify key interviewees. As noted earlier, the researchers had developed a mutual relationship with Grameen senior staff from interactions during an earlier study. The first phase of data collection began in April, once the other participants were selected and agreed upon, the researchers reached out to them through an official letter sent via email to notify them of their selection to participate in the study. The official letter requesting the interviewees to participate in the study was written using non-coercive language, and it clearly stated that participation was voluntary. The official letter from the researchers was appended with a letter from Grameen 
Foundation's Director of Financial Inclusion explaining the agreement between Grameen Foundation and the researchers to conduct this study, the goal of the research, the timeline, expected outcomes, and thanking the participants in advance. The research participants acknowledged and signed an informed consent form prior to the interviews.

In the second phase from May 2019 - July 2019, we continued data collection and development of an overall timeline with identification of major MF innovation efforts and results. Interviews with staff overseas were successfully conducted via Skype. We also collected and analyzed any relevant secondary source of information on Grameen Foundation and the research question and theories of interest for this study. All interviews were recorded and transcribed using an audio transcription service: Temi (https://www.temi.com). We wrote reflective memos immediately following each interview and crosschecked facts and impressions within 24 hours. We also provided periodic reports to Grameen Foundation management to help establish a solid timeline, and as the study progressed, we asked the interviewees to review the findings to resolve ambiguities and validate credibility and trustworthiness of interpretations (Patton, 2002).

In the third phase from August 2019 - November 2019, based on feedback from the Dissertation Proposal defense, and after an initial attempt at data analysis, we narrowed down the key questions we wanted to research further and conducted further data collection. The final interviews included the Country Director of Grameen India, Head of Programs Grameen India, and the Technical Advisor, Agriculture Innovation, based in Colombia. Detailed data analyses and development of a longitudinal account of MF innovations at Grameen Foundation followed. This iterative approach was advantageous in helping to refine our thematic coding, theory and to ensure that we had rich and targeted data for our research. 
Finally, in the fourth phase from December 2019 - April 2020, we began the development period of the dissertation that entailed revising the dissertation from the front end between advisor, candidate, and the entire committee, iteratively analyzing data, considering if further data should be collected and storing it in a secure database using NVivo. Dissertation development involved writing a coherent single document with all the completed sections of the dissertation in an acceptable format. Once the first draft of the results was written, it was subject to further review by the dissertation advisor and committee. After several iterations of the results section, the discussion and conclusion sections were written, and the dissertation was made ready for defense. After the oral defense on April 30, 2020, final revisions were made before the dissertation was uploaded in Scholar Works on May 11, 2020.

\section{Figure 3: The Data Collection Process}

Phase 1 (March - April)
Institutional Review Board
approval. Initial insight
meeting between Grameen
Foundation and researchers

Phase 3 (July November) Second wave of Data collected Detailed data analysis

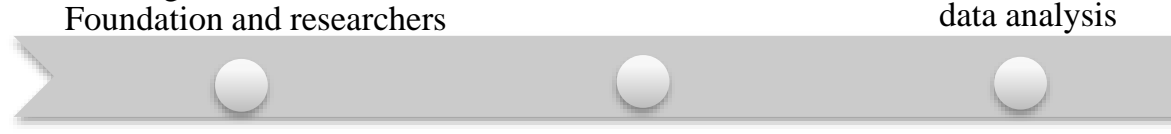

Phase 2 (April - July)

Systematic first wave of

data collection

continued, review, trascribing and storage
Phase 4

(November 2019

- April 2020)

Dissertation development and defense

A total of twelve Grameen staff and affiliates participated in the study. Each participant was interviewed at least twice about one hour in each session. The participants were based at the US headquarters in Washington D.C. and other US remote locations such as Sacramento and Texas, depending on their availability. All participants were directly involved in the design, implementation, partnership building, professional and technical service provisioning of innovating financial solutions at Grameen Foundation. Their titles were: Senior Director of Financial Inclusion, based in Sacramento, California and directors of the financial services 
solutions (i.e.) Director of Bankers without Borders based in Washington D.C., Director of Agriculture Financing based in Sacramento, California, the Director of Research, based in Texas, Regional Director for Latin America based in Ecuador/Mexico, Country Manager Grameen Foundation in Ghana, Regional Director East Africa based in Uganda, Director of Program Strategy at Grameen Foundation India, the Chief Executive Officer at Grameen Foundation India, Head of Country Operations at Grameen Foundation Philippines, Technical Advisor, Agriculture Innovation based in Colombia and the Chief Executive Officer of Grameen Foundation's stakeholder, Taroworks ${ }^{\mathrm{TM}}$ Inc., based in California.

\section{V.2 Data Analysis}

To account for the complexity of analyzing qualitative data, we organized the empirical material and focused on themes and timelines. We conducted a five-step analysis: (1) thematic analysis of data to identify key innovation programs at Grameen; (2) chronological analysis of activities within each innovation program (2009-2019); (3) coding of all data based on key DCT concepts; (4) use of coding to analyze each innovation program in detail through the lens of DCT; and 5) analysis across all innovation programs through the lens of DCT.

The first step included thematic coding of data about key program innovations at Grameen. We coded the interview transcripts and archival data being mindful to look for overlaps in concepts and any emerging ones (Creed, Scully \& Austin, 2002). We used memo writing and data displays to understand the data (Lempert, 2007) and to refine our timeline. To confirm or disconfirm evidence, we reviewed the interview transcripts, reports, field notes, and Grameen Foundation documents (Miles \& Huberman 1994) again. We stored all interview transcripts, documents, and notes in NVivo 11.0 to ensure credibility (Gioia, et al., 2013; Sonenshein, 2014). We iterated between interview data, archival data, extra interviews to 
compare our analysis (Glaser \& Strauss, 1977) and to search for contradictions and inconsistencies checking them against our theory. For instance, we found innovation activities that Grameen Foundation originated and had spun off, such as TaroWorks TM, Poverty Probability Index ${ }^{\circledR}(\mathrm{PPI})$, and others even though Grameen Foundation still has partial ownership of them. These professional services have been used by many NGOs in scaling their financial interventions, hence the need to categorize them. This iterative process of coding thematically from the material, as referenced in Table 4 allowed us to identify four innovation programs (IPs) and these are: 1. Agriculture Finance (AF), 2. Health Finance (HF), 3. Digital Finance (DF) and 4. Scaling Solutions (SS).

The next step was the chronological analysis of activities within each program innovation. To build the longitudinal narrative of how Grameen Foundation innovated its financial solutions over a ten-year period (2009-2019) required returning to the data, archival records, and websites to get a deeper sense of when activities began and when they ended (Miles, et. al., 1994). Keeping in mind that Grameen Foundation implemented multiple IPs in multiple countries and that it was likely to find an overlap of activities, this step allowed us to identify activities within each innovation program.

In the third step, we were able to identify and aggregate the key activities within each IP. Some IPs had more than others; our analysis shows a total of 20 activities across 4 IPs, as indicated in Table 4. Starting at stage 3, we applied DCT to each activity within the program innovation. We developed a theoretical perspective that connected to Dynamic capabilities core concepts going back and forth between (Strauss \& Corbin 1990) data and our theory concepts. For example, we started off with 2 theories, but through this iterative analysis we had to drop one; Punctuated Equilibrium, (Newman, et. al., 1992) and kept DCT because we found that 
DCT's core concepts of seizing, sensing and transforming were more applicable to our study.

Each activity of innovation was analyzed through the concepts of DCT from the ordinary capabilities to sensing, seizing and transforming and the outcomes or VRIN, as noted in Table 3. Finally, at the end of each program innovation, we show a summary table of the application of DC to activities within that program.

Step 4 consisted of analyses across all innovative programs through the lens of DCT demonstrating how Grameen Foundation innovated across programs, we applied DCT across all 4 IPs in a summary table 8 and demonstrated how programs compared and contrasted. All IPs had a timeline for a total of 4 timelines figures, followed by text narratives on each activity within programs, adding the cross program analysis table resulted in 5 results tables.

Finally, step 5 consisted of a summary of the results based on engaged scholarship principles of iteratively collecting and interpreting knowledge and evidence, exploring and testing ideas, and discovering and evaluating alternatives as described in Mathiassen (2017) as adopted from Frisk, et al. (2014). To capture any new and emergent patterns observed from the data on how Grameen Foundation innovated its product, services, and process activities to improve financial inclusion, we had a final cross analysis summary (6.5) also illustrated in Table 9. It is imperative to note that one of the investigators in this study has extensive work experience in economic development, having worked humanitarian relief agencies that focused on economic empowerment with a focus on microfinance activities for rural women.

\section{V.3 Inter-coder Reliability and External Validity}

Inter-coder reliability in qualitative studies is applied to address inconsistencies in the answers to open-ended questions provided by the respondents (Carey, et al., 1996). Two researchers assessed answers to three interview scripts separately. They rated the answers to ten 
questions excluding the background section using $2 \times 2$ scale of high or low, and they scored responses based on how closely the respondents answered the question and understanding of the questions. This exercise was done twice; in the first round of assessment, there was a misunderstanding of terminology. The inter-rater reliability for the raters was found to be kappa $=0.92(\mathbf{p}<.0 .001)($ see appendix 2$)$. External Validity has to do with establishing the domain into which a study's findings can be generalized. In this dissertation, we follow analytical generalization described further in Table 4, following closely with guidelines to external validity for a single case study in Yin (1994, p.43) writes:

"Critics typically state that single cases offer a poor basis for generalizing. However, such critics are implicitly contrasting the situation to a survey research, where a "sample" (if selected correctly) readily generalizes to a larger universe. This analogy to samples and universe is incorrect when dealing with case studies. This is because survey research relies on statistical generalization, whereas case studies (as with experiments) rely on analytical generalization. In analytical generalization, the investigator is striving o generalize a particular set of findings to some broader theory."

Table 4: Data Analysis and Coding

\begin{tabular}{|c|c|c|c|}
\hline $\begin{array}{l}\text { Level } 1 \\
\text { Thematic Coding of } \\
\text { Innovation } \\
\text { Programs }\end{array}$ & $\begin{array}{l}\text { Level } 2 \\
\text { Timeline of } \\
\text { Innovation } \\
\text { Programs }\end{array}$ & $\begin{array}{l}\text { Level } 3 \\
\text { Activities } \\
\text { per Innovation } \\
\text { Program }\end{array}$ & $\begin{array}{l}\text { Number of } \\
\text { Activities per } \\
\text { Innovation } \\
\text { Program }\end{array}$ \\
\hline $\begin{array}{l}\text { Innovation Program I } \\
\text { Agricuture Finance (AF) }\end{array}$ & 2009-2019 & $\begin{array}{l}\text { AF1, AF2, AF3, } \\
\text { AF4, AF5, AF6, } \\
\text { AF7 }\end{array}$ & 7 \\
\hline $\begin{array}{l}\text { Innovation Program II } \\
\text { Health Finance (HF) }\end{array}$ & 2009-2019 & $\begin{array}{l}\text { HF1, HF2, HF3, } \\
\text { HF4 }\end{array}$ & 4 \\
\hline $\begin{array}{l}\text { Innovation Program III } \\
\text { Digital Finance (DF) } \\
\end{array}$ & 2009-2019 & $\begin{array}{l}\text { DF1, DF2, DF3, } \\
\text { DF4 }\end{array}$ & 4 \\
\hline $\begin{array}{l}\text { Innovation Program IV } \\
\text { Scaling Solutions (SS) } \\
\end{array}$ & 2009-2019 & $\begin{array}{l}\text { SS1, SS2, SS3, SS4, } \\
\text { SS5, }\end{array}$ & 5 \\
\hline
\end{tabular}




\section{RESULTS}

Grameen Foundation was founded in $1997^{12}$, inspired by the work of Nobel Laureate Muhammad Yunus, founder of Grameen Bank and a global leader in the fight against poverty. Working through a network of MFIs in Africa, the Americas, Asia, and the Middle East, Grameen Foundation had provided microloans and other financial services to 10.9 million people by $2009 .{ }^{13}$ Grameen Foundation's expertise lies in the application of digital innovation through its programs. Grameen's integration with the global non-profit Freedom from Hunger in $2016^{14}$, helped to further Grameen Foundation's mission. Bobbi, Director of Research who has worked with both organizations comments:

"When the two NGOs merged they were very similar, whereas Grameen Foundation's programs had a high technology focus, Freedom From Hunger did microfinance with saving groups, so we were able to combine these areas of expertise."

Grameen Foundation designs sustainable, scalable digital financial solutions by orchestrating a partnership of multi-sectorial players. At its core, Grameen Foundation's program innovation is based on human-centered design principles and scalable business practices through its Solutions Innovation Process (SIP). Asked how program innovation is achieved in the design, implementation, and delivery of digital financial solutions, Christian, Director of Financial

Inclusion comments:

"We use the Solution Innovation Process (SIP) based on understanding the needs of the clients. It combines Human Centered Design principles and scalable business practices because everything we do is from the perspective of the market, making sure that it's a solution that can be scalable, and one that can be offered to thousands, even millions of users. So that's the perspective we begin with from the onset, a Solutions Innovation Process, which is at the heart of any design work that we do."

12 www.grameenfoundation.org

13 Ibid

14 Ibid 
Digitally equipped field agents acted as community workers who delivered services and products to remote households. Grameen's focus is to empower rural women and their households through four innovations programs (IPs) whose activities we will discuss in detail below: Agriculture Finance (AF), Health Finance (HF), Digital Finance (DF), and Scaling Solution (SS).

\section{VI.1 Innovation Program I: Agriculture Finance (AF)}

Grameen Foundation's AF program aims to build an empowering ecosystem ${ }^{15}$, shown in Figure 4 below, for rural women and their households by innovating through activities that provide access to sustainable financial services and products, and information and expertise on Good Agriculture Practices (GAPs) that would result in higher yields, peer support, strengthen their resilience to withstand bad weather and access to markets. Mona, Director of Agriculture Financing comments:

"Grameen supports farmers through a combination of activities that use digital technology and data, and work with a rich array of partners from community and women's groups to global agribusinesses."

Figure 6 below outlines a timeline of key AF innovation activities. We applied DCT to each of these activities to show how Grameen Foundation innovated various ordinary capabilities through sensing, seizing, and transforming.

${ }^{15}$ Gatti, G., Gomez, J. \& McCord, M., 2019. Grameen Foundation Agriculture Digital Innovations AgTech Report, October 2019. 
Figure 4: Grameen's Agriculture Finance Portfolio

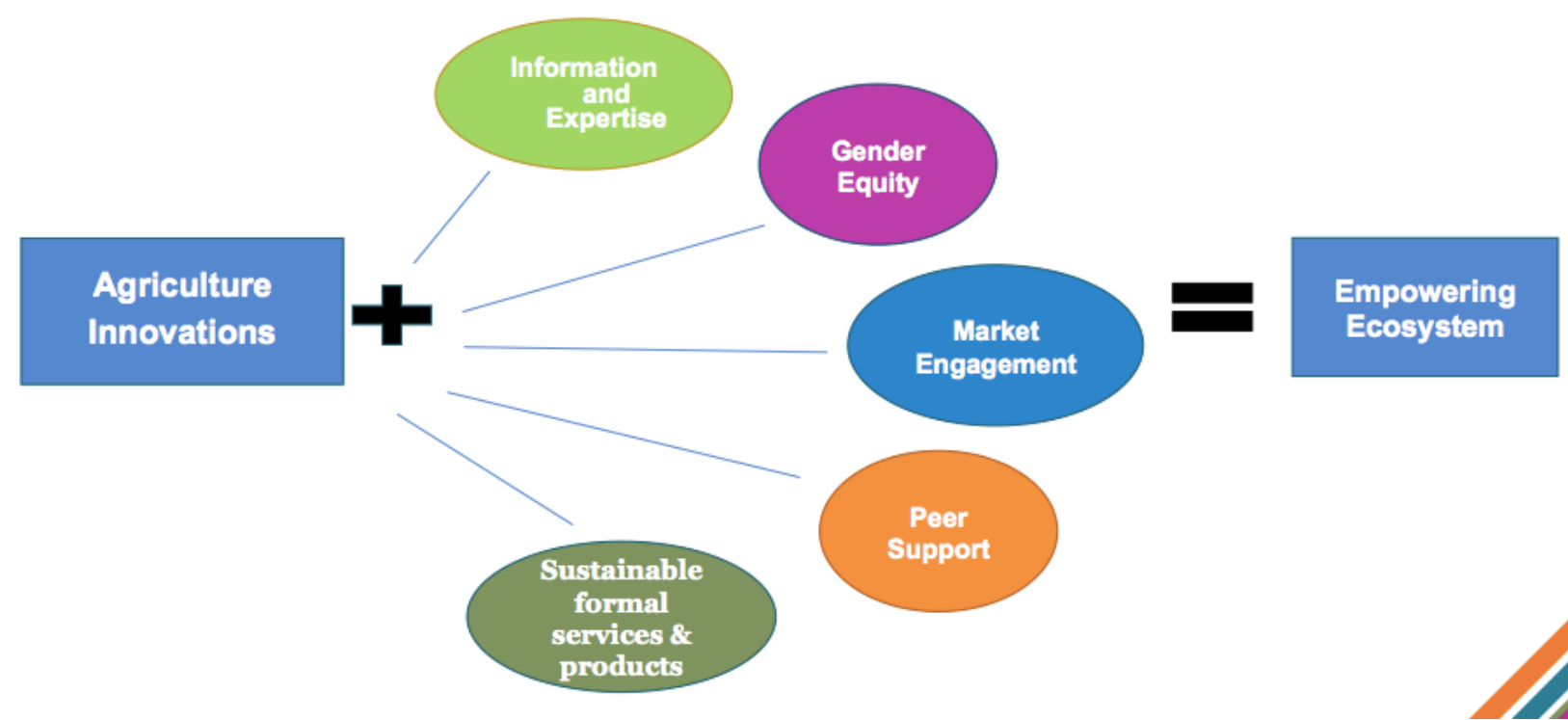

${ }^{16}$ Adapted from: Grameen Foundation Agriculture Digital Innovations AgTech Report, 2019 6.1.1 Community Knowledge Worker (CKW), 2009 - 2019

Sensing: Field agents and farmers in rural Uganda need access to financial services and knowledge on adopting GAPs to improve their productivity and to subsequently gain access to markets in real-time. Grameen Foundation sensed that effective channels of delivering such knowledge to farmers did not exist; they further observed that a combination of poor road infrastructure and the lack of Internet access impaired connectivity. However, the widespread diffusion of mobile technology afforded opportunity to develop connectivity.

Seizing: In 2009, Grameen Foundation partnered with funding from the Bill \& Melinda Gates Foundation to design a mobile data collection tool and mobile app called Community Knowledge Worker $(\mathrm{CKW})^{17}$. The $\mathrm{CKW}$ was launched as a flagship agriculture finance activity

${ }^{16}$ Gatti, G., Gomez, J., McCord, M. 2019 Grameen Foundation Agriculture Digital Innovations AgTech Report, October 2019

${ }^{17}$ CKW Uganda Lessons Learned (2009 - 2014) Executive Summary Grameen Foundation 
that has been replicated with iterations in other countries like Colombia. Judith, East African

Director comments:

"The initiative was one of the first to use smartphone technology and cloud computing in very remote rural setting. While there were several active ICT and mobile agriculture projects starting up in East Africa, most of them relied on SMS services and basic handsets to disseminate targeted information, and few had the capacity to test the types of features and services that more advanced technologies made possible."

The successful implementation of this activity lay in the multi-channel approach that created opportunities to validate and reinforce information, but it also provided valuable escalation paths, on-demand options, and back-end support channels. Trained on the use of mobile technology, a local peer advisor network of ${ }^{18}$ over 1,300 community agents also incentivized was deployed across Uganda. CKW, allowed for more targeted information flow such as production tips to all registered maize or coffee farmers during critical times in the season, as illustrated in Figure $5^{19}$. Farmers were introduced to self-organized savings associations and learned about the requirements of financial lenders. Christian, Director of Financial Inclusion comments:

"Farmers are guided through the supply chain by disseminating tips on Good Agriculture Practices (GAPS) in real time via SMS, call-center or radio services."

${ }^{18}$ Ibid

${ }^{19}$ Ibid 


\section{Figure 5: Example of SMS Message sent via CKW to a Client}

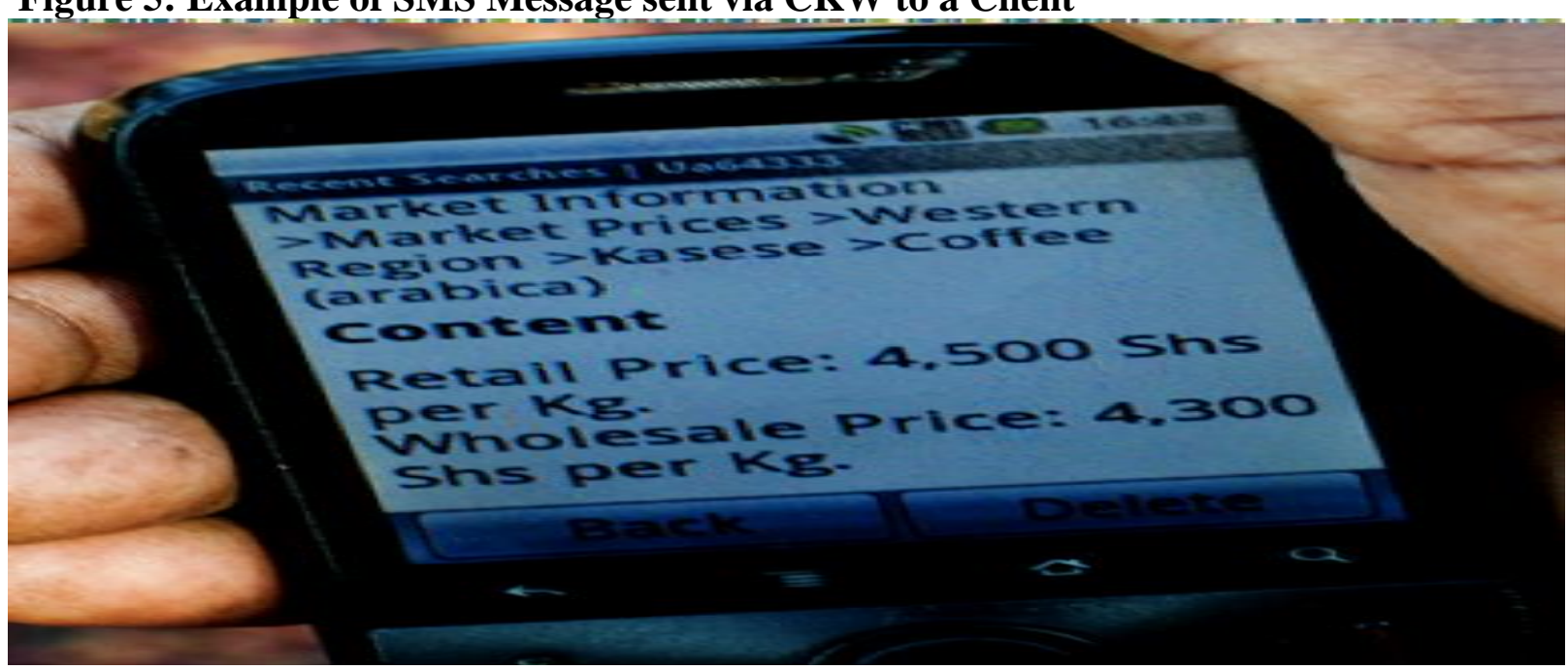

Transforming: The data gathered by field agents were fed into a database of farmer profiles and was shared with Opportunity Bank to make it more readily available to qualify farmers for loans ${ }^{20}$. Registering farmers also enabled the bank to help them build a credit history. Whereas the program did not create a credit rating for individual farmers, it created matrices such as the adoption of good agricultural practices and past production to assess creditworthiness. To obtain a loan, farmers first had to make a deposit equal to 15 percent of the loan value as collateral. The loan was repaid at harvest time, and the interest charged was modest, averaging 10 to 15 percent over a five-month crop season. ${ }^{21}$

Outcomes: Opportunity Bank extended financial services (both accounts and loans) to 6,000 clients and served more than 300,000 registered farmers in remote communities through a network of more than 3,000 peer agent advisors ${ }^{22}$. CKWs completed over 100,000 unique interviews and 1.5 million total interactions with farmers across 43 districts in rural Uganda.

${ }^{20}$ CKW Uganda Lessons-Learned (2009-2014) Executive Summary Grameen Foundation ${ }^{21}$ Ibid

22 Ibid 
Figure 6: Timeline of Agriculture Finance (AF) Innovations

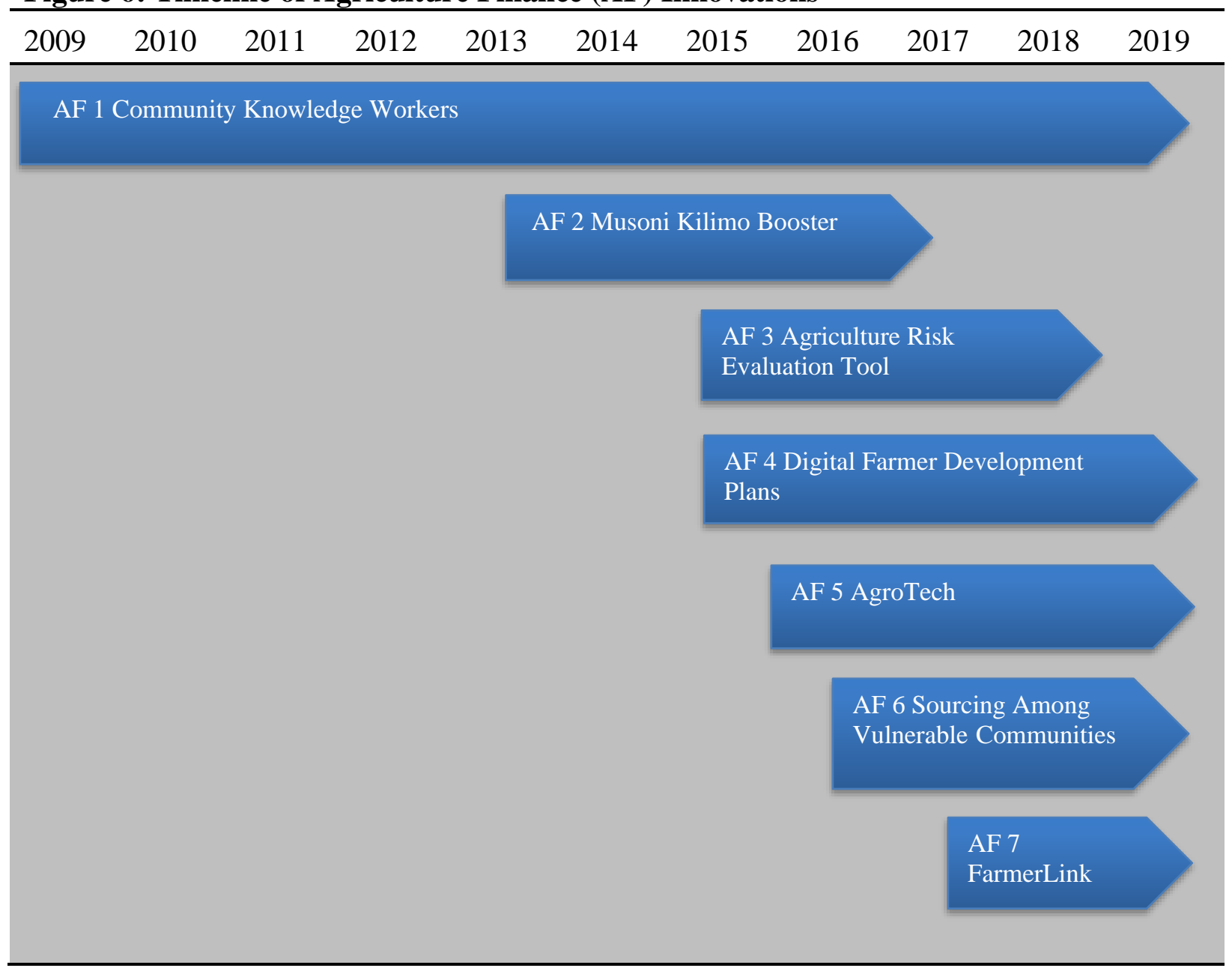

6.1.2 Musoni Kilimo Booster, 2013 - 2016

Sensing: Farmers in Kenya need flexibility in how they access and repay loans. Field agents need to reduce the long waits between application and qualifying farmers' loans. Existing mobile money platforms like Mpesa offer an opportunity to design flexible loan products and faster services for farmers. Christian, Director of Financial Inclusion comments:

"One of the challenges is getting loan duration adjusted to the production cycle which is something farmers usually struggle with because the cycle is too long and Credit terms are too short and the farmers run out of liquidity." 
Seizing: Through Partnership with Musoni, an MFI in Kenya, and funding from the United States Agency for International Development's (USAID) Global Hunger and Food Security Initiative: “Feed the Future,” Grameen Foundation designed Kilimo Booster ${ }^{23}$, a mobile-based agricultural loan application designed specifically for smallholder farmers. Musoni loans came with flexible repayment terms that corresponded to farmers' harvest cycles and cash flow to address the challenge of lack of liquidity. Musoni Kilimo Booster loan officers digitally processed group applications in the field using tablets rendering the process from loan approval to disbursement to repayment $100 \%$ cashless $^{24}$. To successfully Implement Musoni Kilimo Booster loans, Grameen Foundation leveraged already existing mobile money platforms in Kenya like Mpesa ${ }^{25}$, which enabled funds to be disbursed directly into farmers' mobile money accounts no more than 72 hours after a loan was approved.

Transforming: Musoni loans transformed the way participating farmers accessed financial products and services. Musoni access included a combination of mobile money wallets and flexible payment schedules that matched their crop production cycles, eliminated farmers' paperwork, and relieved clients of the burden of traveling to distant service points to apply for loans. Most importantly, Musoni Kilimo booster loans offered flexible repayment terms that suited farmers' cash flow. ${ }^{26}$ Asked to name which they considered one of the top three most innovative tools at Grameen over the years, Julian, Technical Advisor for Agriculture Innovation comments:

"Another powerful innovation was Musoni. Working with financial services to create the app eased loan processing and how farmers received loans since they already had mobile money

\footnotetext{
${ }^{23}$ www.grameenfoundation.org

${ }^{24}$ Ibid

${ }^{25}$ Ibid

${ }^{26}$ Ibid
} 
wallets. Even though Musoni ended in 2016, it was started way ahead of some of mobile money products we see in the industry today."

Outcomes: From its launch in 2013 through May 2016, ${ }^{27}$ Musoni disbursed 34,000 of these loans worth more US\$2.2 million, and 70\% of group loans were given to women.

\subsubsection{Agricultural Risk Evaluation Tool (ARET), 2015 - 2017}

Sensing: Field agents in Colombia need to have farm-level data on cocoa farmers to assess farmers' risks and opportunities for crop production improvement in order to gain access to global cocoa supply chains. Technological options to capture and analyze farm-level data within Grameen could be leveraged further to improve these assessments.

Seizing: In 2015, ${ }^{28}$ Grameen partnered with Cooperativa de los Andes (COOPERAN), a large coffee cooperative in Colombia, to develop Agricultural Risk Evaluation Tool (ARET). ARET is a salesforce enabled mobile application that collected farm-level data and evaluated the ability of farmers' ability to repay loans based on data on farming practices and size of their farms. ARET's utility is close to a credit-scoring tool for rural farmers; the tool was in the piloting phase by the time this study was conducted. Amelia, Senior Manager of Programs, comments:

"The genesis of ARET was really to understand how we can improve the credit lending process and get more and better data to evaluate and include a larger number of farmers. But also anything that we're doing with monitoring and evaluation and having a dashboard that takes advantage of Salesforce. So I think ARET is a really good example of how we use data to facilitate processes"

The implementation of ARET was through field agents ${ }^{29}$ who collected farm-level data using surveyed from more than 1,500 farmers; data collected from the surveys provided crucial

\footnotetext{
${ }^{27}$ Ibid

${ }^{28}$ www.grameenfoundation.org

${ }^{29}$ Ibid
} 
insights into a farmer's likelihood to default on a loan. This data was used to further segment farmers into eight risk groups that helped COOPERAN make decisions on whom to serve and how to best serve them with credit and ongoing support.

Transforming: Grameen continued to implement and refine ARET in Colombia ${ }^{30}$. Data collected by field agents and credit officers were used to assess risk, and to develop individualized farm management plans that help farmers raise their productivity and credit scores.

Outcomes: Full development and deployment of this credit scoring tool by Grameen Foundation is projected to bring about scaling that will enable "millions of smallholder farmers to access loans, improve the productivity of their farms, and improve the efficiency of the credit process, " comments Julian, Technical Advisor for Agriculture Innovation.

\subsubsection{Digital Farmer Development Plan (DFDP), 2016 - 2019}

Sensing: Smallholder cocoa farmers and field agents need to share information on how to get certification if they are to gain access to global cocoa supply chains. Widespread diffusion of mobile technology offers an opportunity to share information on certification via multiple channels like radios afford opportunities for ongoing dialogue.

Seizing: Grameen partnered with Rainforest Alliance and Cocoa agribusiness Mars Inc., to design SAT4 an android and cloud-based technology with diagnostic analysis and rules-based predictive tools used to assist decision-making. SAT4 complemented an existing innovation that utilized Farmer Development Plans, the resulting digital farmer development plans (DFDPs) came with added features enabling access to a mobile tool that combined agronomy, household finances, farm economics, tailored training and advice for individual farmers. DFDP was perhaps

${ }^{30} \mathrm{Ibid}$ 
Grameen Foundation's largest AF initiative, by the time this study was conducted, DFDP was being piloted in 3 countries: Colombia, Ghana and Indonesia. On DFDPs design, Alfred, Country Director, Ghana comments:

"We've developed a digital platform and tool that field agents use to profile cocoa farmers to understand the financial record as well as the socioeconomic status of the farming families. The tool does two things: Data that is collected undergoes profiling to understand the socioeconomic status of the family farming. The data from the assessments of their farm combines with a smart logic that generates specific good agriculture practices for farming households to implement within 1-7 years."

The integration of an existing farm development plan and SAT4 worked in five steps as follows: ${ }^{31}$ Field agents used digital technology to capture real-time data on farmers, their farm profiles, and obtained data points on household members, family finances, farm economic profile, and certification practices. 2. Field agents captured adoption observations that covered 14 farming indicators from plant material to farm condition, agricultural practices, and soil management. 3. Based on 1 and 2, the digital farm development plan (DFDP) generated a sevenyear investment plan, with profit \& loss calculations, and recommended monthly activities. These plans were based on data collected from individual farmers such as family income, plant material used, farm condition, and agriculture practices. 4. Field agents discussed the plan with farmers, made adjustments as needed, and agreed on a future plan. 5. DFDPs also used an internal management system to fast-track farmer certification in sustainable farming practices, which in turn provided them access to higher paying cocoa markets. Julian, Technical Advisor for Agriculture Innovation comments:

${ }^{31}$ Gatti, G., Gomez, J. \& McCord, M., 2019. Grameen Foundation Agriculture Digital Innovations AgTech Report, October 2019 
"DFDPs also uses an internal management system to fast-track farmers' certification in sustainable farming practices, which in turn provides them with access to a higher-paying cocoa market."

Transforming: Data generated by DFDPs provided insights for all suppliers and financial institutions. It also helped to secure farmers in the supply chains and banks got better insights into farmers' profiles and likelihood of success with MF. Alfred, Country Director Ghana comments:

"DFDP generates seven year sustainable business plans that allow farmers to plan ahead, improve their productivity and cement their place in the cocoa supply chain. In the future, Grameen Foundation plans to deliver DFDP through a social enterprise (a future joint venture) with Rainforest Alliance. Grameen had plans to integrate satellite imagery with the DFDP app to streamline the monitoring process and provide greater insights into dynamic environmental industry platform and share the social enterprise services with the broader industry clients ${ }^{32}$.

Outcomes: In Indonesia, DFDP reached 1200 farmers, and in Ghana, 2090 farmers benefited from long-term planning using DFDP by attaining a living income equivalent to 1.5 - 2 MT per hectare. Lastly, in Colombia DFDP reached 3,600 cocoa farmers, of which 1,000 were women who received individualized digital farm development plans and coaching by volunteer community agents ${ }^{33}$.

6.1.5 AgroTech, $2015-2019$

Sensing: Field agents in Ghana need to communicate critical information to farmers in remote areas on how to improve yields, how to access financing, and how to improve their food security. Multiple communication channels offer an opportunity to scale outreach, especially to women using their local languages and communicated at the most convenient times that suit rural farm women.

${ }^{32}$ Gatti, G., Gomez, J. \& McCord, M., (2019). Grameen Foundation _ Agriculture Digital Innovations, AgTech Report.

${ }^{33}$ Ibid 
Seizing: In 2015, Grameen Foundation in partnership with the New Alliance ICT Extension Challenge Fund, Ghana's Ministry of Food and Agriculture, ACDI/VOCA (a global NGO), Digital Green, and Farm Radio International to launched AgroTech ${ }^{34}$, a mobile app that could be used multiple channels. Field agents equipped Agrotech software on their smart phones, operated a radio campaign with Farm Radio International, and used farmer-led video production and dissemination to reach poor and remote areas with high rates of illiteracy and limited cellular network coverage. Alfred, Country Director, Ghana, comments:

"To engage women farmers, AgroTech radio programs aired at times convenient for women, they formed radio listener groups that included a female co-host in the radio programming, and tailored the AgroTech service package to address women's specific roles in farming and in the food supply system."

Transforming: AgroTech's mobile app-enabled both government and private company field agents to quickly understand and analyze farmers' needs and crop history; to deliver agricultural advice, and to procure loans to purchase farm supplies like fertilizers and quality seeds. Maize (corn) productivity for women AgroTech radio listeners was more than twice that of farmers in non-farm radio communities. ${ }^{35}$

Outcomes: By April 2018, AgroTech and a follow-on project had reached 500,687 farmers, one-third of whom were women through radio, video, and digital farm management plans generated from farmer profiling data collected via one of the DFDPs. A significant longterm outcome of Agrotech was its adoption by the Ghanaian government, comments Alfred, Country Director, Ghana:

"Although the program has concluded, the collaboration with Ghana's Ministry of Food and Agriculture helped to promote new government efforts to transform the national agricultural

${ }^{34}$ Ibid

35 Ibid 
extension advisory system into a modern, business-oriented, demand-driven and accountable business service led by the private sector."

\subsubsection{Sourcing Among Vulnerable Communities, 2016 - 2017}

Sensing: Farmers in Antioquia, Colombia, need to increase their production to achieve food security, reduce the redundancies lost in fulfilling supplier orders in real-time, and gain access to financial services and markets. Technological solutions for data collection and analysis to strengthen market engagement and financial access exist within Grameen.

Seizing: Grameen in partnership with Foundations Salva Terra, a nonprofit that promotes organic farming among vulnerable communities and Orgaenik Foundation, a nonprofit that trains farmers and gives them access to inputs and markets, developed the M-Sourcing tool. ${ }^{36}$ The MSourcing solution was built on a salesforce app cloud that utilized TaroWorks ${ }^{\mathrm{TM}}$ to manage data collection and to process orders and transactions between buyers, typically restaurants, supermarkets, and farmers. Field agents used the digital tool to collect and disseminate information that helped farmers improved their quality, increased their output, and connected them to large-scale buyers.

Transforming: This tool offered new and diverse ways of how farmers accessed and marketed their products. M-Sourcing provided relevant information for all actors in the value chain. Providing information for decision making brought transparency and efficiency to marketing processes, brought traceability of managed orders, reduced administrative time and costs, and provided information for crop planning guided by market demand. ${ }^{37}$

36 Ibid

37 Ibid 
Outcomes: In the pilot, there was a 90 percent decrease in ordering mistakes, and farmers got paid more quickly - in seven days instead of 40 , hence overcoming the obstacle of long payment cycles that previously prevented farmers from selling to formal markets. ${ }^{38}$

6.1.7 FarmerLink, $2016-2018$

Sensing: In the Philippines, smallholder coconut farmers are often left out of the supply chain, and worse, they are faced with extreme weather conditions that have adverse effects on their economic livelihoods. Field agents and farmers need to share weather-related information to build farmers' resilience to withstand extreme weather and volatile markets. Widespread diffusion of mobile technology offers an opportunity to disseminate timely information on early warning signs, access to market, and financial solutions.

Seizing: Grameen Foundation partnered with the Philippines Coconut Authority, coconut exporters Franklin Baker and Nutiva; and the microfinance oriented People's Bank of Caraga, to develop FarmerLink, using digital technology $y^{39}$. FarmerLink provided useful advice to farm households in the form of financial security, health protection, access to weather information, and tools for adapting to extreme and hard-to-predict events. Christine, Country Manager, Philippines comments:

"Supported by the Global Resilience partnership, FarmerLink was launched to address change in weather conditions, issues on productivity, access to farming inputs and loans. Coconut smallholder farmers are some of the poorest with $60 \%$ living at or below the poverty line, with an annual income of \$440."

Equipped and trained on the use of digital technology, ${ }^{40}$ field agents provided farmers with complimentary resources: agricultural training via SMS on their mobile phones,

\footnotetext{
${ }^{38}$ Ibid

${ }^{39}$ Ibid

${ }^{40} \mathrm{Ibid}$
} 
connections to high-value markets, support for organic certification, extreme weather alerts, training in financial management, and access to financing. Alfred, Country Director, Ghana, comments:

"Implementing financial inclusion with a digital tool like FarmerLink allows us to analyze data in real time. For example, we can tell how many women in remote areas received loans, it allows us to deploy information to farmers via SMS messaging on credit access, good agriculture practices and so on to increase their income and resilience of their farms."

Transforming: FarmerLink had engaged 27,557 farmers with SMS campaigns containing good agricultural practices, cash management practices, and pest and disease information. More than 3,000 farmers ${ }^{41}$ were able to protect their crops against a prolonged drought by following FarmerLink advice. Christina, a farmer who participated in Grameen Foundation's FarmerLink program (cited below):

"I have a 4.5-hectare farm which I inherited from my parents. My plants are coconuts, mangoes and other fruits. Between them, I have intercropped cacao trees. Now, I am part of FarmerLink and it gives me continuous [text alerts] about farming.... it's good to take all the precautions from the text messages. The plants didn't dry up because of the ground cover and regular watering. Thanks God, our cacao plants survived. They are still under the coconut trees." 42

Outcomes: FarmerLink achieved so much scale that when the partnership with Grameen Foundation concluded in ${ }^{43}$ May 2018, the Philippines Coconut Authority developed plans to extend its national coverage. Also, FarmerLink engaged close to 28,000 cocoa farmers with SMS campaigns providing farmers with tips to improve productivity and boost their sales. Other factors that attributed to FarmerLink's success were as Christine, Country Manager, Philippines, comments: "Combining the power of mobile technology and human networks to improve productivity, access to markets and financial services."

${ }^{41}$ Ibid

${ }^{42}$ Agriculture finance Philippines FarmerLink Evaluation Report, 2019

${ }^{43}$ Ibid 


\subsubsection{Summary of AF Innovations}

Sensing: Grameen Foundation sensed that small holder farmers in remote places needed access to loans, savings, insurance, farm inputs, market access, access to supply chains, weatherrelated information and GAPs in real-time as seen in Table 5, but the lack of internet connectivity limited field agents and the farmers from experiencing shared knowledge. Grameen Foundation identified that the widespread use of mobile technology and other digital solutions afforded opportunities to develop connectivity and effectively deliver a variety of AF products and services.

Seizing: Grameen seized opportunities to innovate its AFs in three ways: First, by designing innovative apps enabled by technology such as CKW, Kilimo Booster, M-Sourcing, DFDP that were used to collect and analyze micro-targeted data in real-time using Taroworks (Grameen's own software), to understand the most productive farm level inputs that would help farmers become more profitable. Secondly, they seized by orchestrating a network of partners with value propositions to financially support the design, implementation, and sustain the innovations at scale. Mona, Director of Agriculture Financing comments:

"We do the orchestrating of these networks early on. And so we bring together a number of partners, including NGOs, MFI, Cooperatives, agribusinesses and others to design inputs and linkages that address farmers need. So we look at the whole business ecosystem at the very start."

Thirdly, they trained peer farm agents on the use of digital apps. These agents, in turn, reached out directly to farmers using a multi-channel approach such as sending SMS, video, radios directly to farmers smart phones as was the case with AgroTech and FarmerLink and MSourcing. Hence, they provided farmers with linkages to financial products and services, 
markets, farm inputs, weather-related information, technical guidance on good agriculture practices, and training on certification with a strong focus on women farmers.

Transforming: Grameen transformed by continuously reconfiguring its business model based on lessons learned from one context, for example, when funding for the CKW ended in Uganda, Bobbi, Director of Research comments:

"That was a lesson we learned early on, it pushed Grameen to think a lot more about how to combine technology with some sort of business model. Like we have to be very clear as to whether we think we can spin it off as its own social enterprise or that there's actually a business or a government or somebody else that's willing to take it on post project."

Grameen Foundation's SIP approach permitted the continuous improvement of products, services, and processes as they underwent prototyping, testing, piloting, iteration before launching in different contexts, as was the case for $\mathrm{CKW}$, which was launched with iterations in Columbia and DFDPs in Ghana, Indonesia, and Colombia. Bobbi, Director of Research comments:

"Sometimes the technology gets tweaked because I think what happens is that you gain lessons in one place, you decide what worked or didn't work. And so the next iteration of it gets included in the next version. And I would say that this particular approach is a result of years of making adaptations to this concept."

The creation of DFDPs was an example of Grameen Foundation's integrated solutions where two cloud based products were combined to improve clients' access to loans and savings, markets, that included financial planning embedded with a seven-year cash flow forecast drawn from the farm development profiles generated it generated As such, they had several activities going on at different stages, but the ultimate goal was to create scalable and sustained innovations that enabled farmers gain direct access into global supply chains, Julian, Technical Advisor for Agriculture Innovation comments: 
"In designing these innovations we focus on not just one but integrated solutions, for instance, creating financial linkage in agriculture and in health with our partners."

Outcomes: Agriculture Finance was by far one of the largest innovation programs at Grameen Foundation, with many activities, but in this study, we focused on seven key innovations, as seen in Table 5 below. Digital farming solutions have enabled millions of small holder farming communities who comprise seventy percent of the world's poor gain access to loans, savings, crop insurance, digital payments that catalyzed entrepreneurship and growth. Empowering family farms with digital access to the formal agriculture supply chain was a proven way to increase crop production, productivity, and income ${ }^{44}$. The scalable diffusion of Agriculture finance innovations was very impactful in countries such as Ghana with Agrotech and the Philippines with Farmer Link, where governments adopted Grameen Foundation's model to inform their national agricultural platforms. Christine, Country Manager, Philippines comments:

"We create market based solutions that we can spin off to organizations, NGOs and even governments."

${ }^{44}$ www.grameenfoundation.org 
Table 5: Summary of Agriculture Finance (AG) Innovations (2009 - 2019)

\begin{tabular}{|c|c|c|c|c|c|}
\hline \multirow{2}{*}{ Activity } & \multirow{2}{*}{ Ordinary Capability } & \multicolumn{4}{|c|}{ Dynamic Capability } \\
\hline & & Sense & Seize & Transform & Outcomes \\
\hline $\begin{array}{l}\text { Community } \\
\text { Knowledge Workers } \\
\text { (CKW) } \\
2009-2019\end{array}$ & $\begin{array}{l}\text { Connecting Farmers to } \\
\text { Finance - access to } \\
\text { loans, savings, } \\
\text { insurance, farm inputs, } \\
\text { market access, access to } \\
\text { supply chains, weather- } \\
\text { related information and } \\
\text { good agricultural } \\
\text { practices (GAPs). }\end{array}$ & $\begin{array}{l}\text { Field agents and farmers } \\
\text { in rural Uganda need to } \\
\text { share knowledge on } \\
\text { access to financial } \\
\text { services and farm-related } \\
\text { information in real time. } \\
\text { Widespread diffusion of } \\
\text { mobile technology affords } \\
\text { opportunity to develop } \\
\text { connectivity apps. }\end{array}$ & $\begin{array}{l}\text { Agents introduced good } \\
\text { agricultural practices (GAPs) } \\
\text { to farmers and organized them } \\
\text { in self-organized savings } \\
\text { associations. } \\
\text { With funding from Bill \& } \\
\text { Melinda Gates Foundation, } \\
\text { Grameen Foundation designed } \\
\text { the CKW, a cloud based } \\
\text { mobile app. }\end{array}$ & $\begin{array}{l}\text { Farmers who adopted GAPs } \\
\text { increased production and } \\
\text { creditworthiness. } \\
\text { A local peer advisor network } \\
\text { of over } 1,300 \text { community } \\
\text { agents equipped with two-way } \\
\text { real-time information to } \\
\text { improve farmers' access to } \\
\text { financial services } \\
\text { implemented CKW across } \\
\text { Uganda. }\end{array}$ & $\begin{array}{l}\text { CKW served more than } \\
300,000 \text { registered } \\
\text { farmers. CKW agents } \\
\text { completed over } 100,000 \\
\text { unique interviews and } 1.5 \\
\text { million total interactions } \\
\text { with farmers in } 43 \text { rural } \\
\text { districts. } \\
\text { Over } 6,000 \text { households } \\
\text { received loans through } \\
\text { Opportunity bank. }\end{array}$ \\
\hline $\begin{array}{l}\text { Musoni Kilimo } \\
\text { Booster } \\
\text { 2013-2016 }\end{array}$ & $\begin{array}{l}\text { Connecting Farmers to } \\
\text { Finance - access to } \\
\text { loans, savings, } \\
\text { insurance, farm inputs, } \\
\text { market access, access to } \\
\text { supply chains, weather- } \\
\text { related information, and } \\
\text { GAPs. }\end{array}$ & $\begin{array}{l}\text { Farmers need flexibility in } \\
\text { how they access and repay } \\
\text { loans. Field agents need to } \\
\text { reduce the long waits } \\
\text { between application and } \\
\text { qualifying farmers' loans. } \\
\text { Existing mobile money } \\
\text { platforms like Mpesa offer } \\
\text { an opportunity to design } \\
\text { flexible loan products and } \\
\text { faster services to farmers. }\end{array}$ & $\begin{array}{l}\text { Musoni Kilimo Booster loan } \\
\text { officers digitally processed } \\
\text { group applications in the field } \\
\text { using tablets rendering the } \\
\text { process } 100 \% \text { cashless. } \\
\text { Through funding from USAID } \\
\text { and a partnership with } \\
\text { Musoni, Grameen Foundation } \\
\text { designed Kilimo Booster, a } \\
\text { mobile-based agricultural loan } \\
\text { service platform. }\end{array}$ & $\begin{array}{l}\text { Loan officers leveraged } \\
\text { Mpesa, an existing mobile } \\
\text { money platform to } \\
\text { provide.72-hour loan approval } \\
\text { with funds disbursed directly } \\
\text { into farmers' mobile money } \\
\text { wallets. } \\
\text { The loans came with flexible } \\
\text { repayment terms that } \\
\text { corresponded to farmers' } \\
\text { harvest cycles and cash flows }\end{array}$ & $\begin{array}{l}\text { Musoni, the MFI partner, } \\
\text { disbursed } 34,000 \text { loans } \\
\text { worth more US } \$ 2.2 \\
\text { million, and } 70 \% \text { of these } \\
\text { group loans went to } \\
\text { women. }\end{array}$ \\
\hline $\begin{array}{l}\text { Agriculture Risk } \\
\text { Evaluation Tool } \\
\text { (ARET) 2015 - 2017 }\end{array}$ & $\begin{array}{l}\text { Connecting Farmers to } \\
\text { Finance - access to } \\
\text { loans, savings, } \\
\text { insurance, farm inputs, } \\
\text { market access, access to } \\
\text { supply chains, weather- } \\
\text { related information, and } \\
\text { GAPs. }\end{array}$ & $\begin{array}{l}\text { Field agents in Colombia } \\
\text { need to have farm-level } \\
\text { data on cocoa farmers to } \\
\text { assess their risks and } \\
\text { opportunities to enable } \\
\text { their access to global } \\
\text { cocoa supply chains. } \\
\text { Technological options to } \\
\text { capture and analyze farm } \\
\text { level data within Grameen } \\
\text { could be leveraged. }\end{array}$ & $\begin{array}{l}\text { Farm-level data was captured } \\
\text { via SMS using search } \\
\text { application that tracked farmer } \\
\text { and crop information. } \\
\text { Through partnership with } \\
\text { Cooperativa Delos Andes, } \\
\text { Grameen Foundation designed } \\
\text { ARET, a mobile app that } \\
\text { collects farm-level data using } \\
\text { salesforce-enabled } \\
\text { technology. }\end{array}$ & $\begin{array}{l}\text { ARET connected Farmers to } \\
\text { financing and provided a } \\
\text { detailed financial plan with } \\
\text { predictive analytics used to } \\
\text { assess risk, and to develop } \\
\text { individualized farm } \\
\text { management plans aimed at } \\
\text { improving farmers' } \\
\text { productivity and credit-scores. }\end{array}$ & $\begin{array}{l}\text { Still in the pilot phase, } \\
\text { ARET is projected to } \\
\text { bring about scaling that } \\
\text { will enable "millions of } \\
\text { smallholder farmers to } \\
\text { access loans, improve the } \\
\text { productivity of their farms, } \\
\text { and improve the efficiency } \\
\text { of the credit process." } \\
\text { according to Julian, } \\
\text { Technical Advisor for } \\
\text { Agriculture Innovation. }\end{array}$ \\
\hline
\end{tabular}




\begin{tabular}{|c|c|c|c|c|c|}
\hline $\begin{array}{l}\text { Sourcing Among } \\
\text { Vulnerable } \\
\text { Communities } \\
2016-2017\end{array}$ & $\begin{array}{l}\text { Connecting Farmers to } \\
\text { Finance - access to } \\
\text { loans, savings, } \\
\text { insurance, farm inputs, } \\
\text { market access, access to } \\
\text { supply chains, weather- } \\
\text { related information and } \\
\text { GAPs. }\end{array}$ & $\begin{array}{l}\text { Farmers in Antioquia, } \\
\text { Colombia need to increase } \\
\text { their production to } \\
\text { achieve food security; } \\
\text { reduce the redundancies } \\
\text { lost in fulfilling billing } \\
\text { supplier orders in real- } \\
\text { time access, and gain } \\
\text { access to markets. } \\
\text { Technological solutions } \\
\text { for data collection and } \\
\text { analysis to strengthen } \\
\text { market engagement and } \\
\text { financial access exist } \\
\text { within Grameen. }\end{array}$ & $\begin{array}{l}\text { M-Sourcing integrated } \\
\text { farming activities and crop } \\
\text { cycles to forecast and provide } \\
\text { real-time information on } \\
\text { farmer's actual supply } \\
\text { capacity to allow better } \\
\text { integration with } \\
\text { Businesses such as grocery } \\
\text { stores. } \\
\text { In partnership with Salva } \\
\text { Terra, a Colombia nonprofit } \\
\text { Grameen Foundation } \\
\text { developed M-Sourcing, a } \\
\text { salesforce mobile app that } \\
\text { utilized TaroWorks } \\
\text { manage to } \\
\text { process orders, and } \\
\text { transactions between all the } \\
\text { actors in the value chain. }\end{array}$ & $\begin{array}{l}\text { The M-sourcing tool offered } \\
\text { new and diverse ways on how } \\
\text { farmers in Antioquia sourced } \\
\text { and marketed their products. } \\
\text { It brought traceability of } \\
\text { managed order inventory, } \\
\text { payments, and client billing } \\
\text { information, which improved } \\
\text { transparency and efficiency in } \\
\text { the marketing processes. } \\
\text { It reduced administrative time } \\
\text { and costs and provided } \\
\text { information for crop planning } \\
\text { guided by market demand. }\end{array}$ & $\begin{array}{l}\text { Within its first year, using } \\
\text { the tool strengthened } \\
\text { market engagement and } \\
\text { access to finance. In the } \\
\text { pilot, there was a }{ }^{45} 90 \% \\
\text { percent decrease in } \\
\text { ordering mistakes. } \\
\text { Farmers received } \\
\text { payments in } 7 \text { days instead } \\
\text { of } 40 \text { day, thereby } \\
\text { overcoming the long } \\
\text { payment cycle that } \\
\text { prevented farmers from } \\
\text { selling to formal markets. }\end{array}$ \\
\hline AgroTech 2015 - 2019 & $\begin{array}{l}\text { Connecting Farmers to } \\
\text { Finance - access to } \\
\text { loans, savings, } \\
\text { insurance, farm inputs, } \\
\text { market access, access to } \\
\text { supply chains, weather- } \\
\text { related information, and } \\
\text { GAPs. }\end{array}$ & $\begin{array}{l}\text { Field agents need to } \\
\text { communicate critical } \\
\text { information to farmers in } \\
\text { remote areas in Ghana on } \\
\text { how to improve yields, } \\
\text { how to access financing } \\
\text { while improving their } \\
\text { food security. } \\
\text { Multiple communication } \\
\text { channels offer an } \\
\text { opportunity to scale } \\
\text { outreach, especially to } \\
\text { rural women farmers at } \\
\text { different times and in their } \\
\text { language. }\end{array}$ & $\begin{array}{l}\text { Field agents equipped with } \\
\text { AgroTech, operated a radio } \\
\text { campaign, and used farmer- } \\
\text { led video production means to } \\
\text { disseminate information to } \\
\text { poor farmers in remote areas. } \\
\text { Through partnerships with } \\
\text { New Alliance ICT Extension } \\
\text { Challenge Fund, Ghana's } \\
\text { Ministry of Food and } \\
\text { Agriculture, ACDI/VOCA, } \\
\text { Digital Green, and Farm } \\
\text { Radio, Grameen Foundation } \\
\text { designed a mobile app } \\
\text { AgroTech that could be used } \\
\text { on multichannel platform to } \\
\text { reach farmers. }\end{array}$ & $\begin{array}{l}\text { AgroTech's mobile app- } \\
\text { enabled both government and } \\
\text { private company field agents } \\
\text { to quickly analyze farmers' } \\
\text { needs and to facilitate } \\
\text { farmers' ability to secure and } \\
\text { loans. } \\
\text { The government of Ghana } \\
\text { adopted Agrotech's model to } \\
\text { inform its agriculture } \\
\text { extension and agribusiness } \\
\text { platform through the } \\
\text { Ghanaian Ministry of Food } \\
\text { and Agriculture. }\end{array}$ & $\begin{array}{l}\text { By } 2018, \text { AgroTech had } \\
\text { reached } 500,687 \text { farmers, } \\
\text { one-third of them women } \\
\text { through radio, video, and } \\
\text { digital farm management } \\
\text { plans generated from } \\
\text { farmer profiling data } \\
\text { collected via one of } \\
\text { Grameen's DFDPs. }\end{array}$ \\
\hline
\end{tabular}

${ }^{45}$ Ibid 


\begin{tabular}{|c|c|c|c|c|c|}
\hline $\begin{array}{l}\text { Digital Farmer } \\
\text { Development Plan } \\
\text { (DFDP) 2016 - } 2019\end{array}$ & $\begin{array}{l}\text { Connecting Farmers } \\
\text { to Finance - access to } \\
\text { loans, savings, } \\
\text { insurance, farm } \\
\text { inputs, market access, } \\
\text { access to supply } \\
\text { chains, weather- } \\
\text { related information, } \\
\text { and GAPs. }\end{array}$ & $\begin{array}{l}\text { Smallholder cocoa } \\
\text { farmers and field agents } \\
\text { need to share information } \\
\text { on how to get certification } \\
\text { if they are to gain access } \\
\text { to global cocoa supply } \\
\text { chains. } \\
\text { Widespread diffusion of } \\
\text { mobile technology offers } \\
\text { an opportunity to share } \\
\text { information on } \\
\text { certification via SMS } \\
\text { multiple channels like } \\
\text { radios afford opportunities } \\
\text { for ongoing dialogue. }\end{array}$ & $\begin{array}{l}\text { Field agents used DFDPs to } \\
\text { capture data on farm profiles } \\
\text { and adoption observations } \\
\text { using } 14 \text { farming indicators. } \\
\text { DFDPs generated a seven- } \\
\text { year investment plan, with } \\
\text { profit \& loss calculations and } \\
\text { recommended monthly } \\
\text { activities. } \\
\text { Partnering with Rainforest } \\
\text { Alliance and Mars Inc. } \\
\text { enabled Grameen to design } \\
\text { SAT4 an android- and cloud- } \\
\text { based technology that used } \\
\text { satellite imaging. It came with } \\
\text { added features that produced } \\
\text { comprehensive digital farm } \\
\text { development plans (DFDPs). }\end{array}$ & $\begin{array}{l}\text { Data from DFDPs provided } \\
\text { insights for suppliers and } \\
\text { deepened banks' insights into } \\
\text { farmer needs and operations. } \\
\text { Farmers received sustainable } \\
\text { business plans that allowed } \\
\text { them to plan ahead, improve } \\
\text { their productivity, and cement } \\
\text { their place in the cocoa supply } \\
\text { chains. } \\
\text { Field agents and farmers } \\
\text { regularly monitored DFDP } \\
\text { outputs and made course } \\
\text { adjustments as needed. }\end{array}$ & $\begin{array}{l}\text { By 2019, Thousands of } \\
\text { farmers received } \\
\text { Certification and gained } \\
\text { access to the Cocoa } \\
\text { Supply chains. } \\
\text { In Indonesia, } 1200 \text { farmers } \\
\text { benefited from DFDPs. } \\
\text { In Ghana, } 2090 \text { farmers in } \\
\text { achieved a living income } \\
\text { equivalent to } 2 \text { MT per } \\
\text { hectare. } \\
\text { In Colombia, DFDPs } \\
\text { reached 3,600 cocoa } \\
\text { farmers of which } 1,000 \\
\text { were women. }\end{array}$ \\
\hline $\begin{array}{l}\text { FarmerLink } \\
2018 \text { - } 2019\end{array}$ & $\begin{array}{l}\text { Connecting Farmers } \\
\text { to Finance - access to } \\
\text { loans, savings, } \\
\text { insurance, farm } \\
\text { inputs, market access, } \\
\text { access to supply } \\
\text { chains, weather- } \\
\text { related information, } \\
\text { and GAPs. }\end{array}$ & $\begin{array}{l}\text { Farmers need information } \\
\text { to build their resilience to } \\
\text { withstand extreme } \\
\text { weather and volatile } \\
\text { markets. } \\
\text { Widespread diffusion of } \\
\text { mobile technology offers } \\
\text { an opportunity to } \\
\text { disseminate timely } \\
\text { information on early } \\
\text { warning signs, access to } \\
\text { market, and financial } \\
\text { solutions. }\end{array}$ & $\begin{array}{l}\text { Field agents provided farmers } \\
\text { specific, timely, and } \\
\text { actionable information using } \\
\text { digital technology on } \\
\text { agricultural training via SMS; } \\
\text { connected them to high-value } \\
\text { markets, provided support for } \\
\text { organic certification, sent } \\
\text { extreme weather alerts, } \\
\text { provided training in financial } \\
\text { management, and how to } \\
\text { access financing. } \\
\text { Grameen partnered with the } \\
\text { Philippine Coconut Authority, } \\
\text { coconut exporters Franklin } \\
\text { Baker and Nutiva and the } \\
\text { microfinance oriented } \\
\text { People's Bank of Caraga to } \\
\text { design FarmerLink - a mobile } \\
\text { app that combined satellite } \\
\text { data and farm-level } \\
\text { observations collected using } \\
\text { Taroworks }\end{array}$ & $\begin{array}{l}\text { It came with an early warning } \\
\text { system which provided alerts } \\
\text { directly to farmers' phones } \\
\text { notifying them about extreme } \\
\text { weather events and potential } \\
\text { pests and disease outbreaks. } \\
\text { FarmerLink's success } \\
\text { compelled the Philippines } \\
\text { Coconut Authority to expand } \\
\text { its national coverage even } \\
\text { when the partnership with } \\
\text { Grameen Foundation ended. }\end{array}$ & $\begin{array}{l}\text { Farmerlink engaged close } \\
\text { to } 28,000 \text { cocoa farmers } \\
\text { with SMS campaigns, } \\
\text { enabled them with tips for } \\
\text { improving productivity, } \\
\text { and boost their sales. }\end{array}$ \\
\hline
\end{tabular}




\section{VI.2 Innovation Program II: Health Finance (HF)}

Microfinance is a powerful tool in the fight against poverty and hunger, but its positive impact can be undermined when a client or family member falls ill, causing late payments or even default ${ }^{46}$. HF at Grameen followed a legacy model introduced in 2006 through funding from the Bill \& Melinda Gates Foundation became the flagship activity for HF. The program was implemented through three focus areas: First, to increase access to health services and products for poor women and their families. And secondly, offer health financing, health education, and third, to provide linkages to local health providers. The goal of HF activities enabled clients to save money through savings groups to cover out of pocket health expenses. Amelia, Regional Manager for Latin America comments:

"We found that people still have an issue paying for their health needs and since health often comes up kind of last minute and unexpected, applying for a traditional loan or being able to go to a bank and taking out health savings wasn't always an option."

Figure 7 below is a timeline of the key HF innovation activities. We applied DCT to each of these activities showing how Grameen Foundation innovated HF ordinary capabilities through sensing, seizing, and transforming.

${ }^{46}$ Rogers S, Rao DSK, Satish P, Saha S. (2018). Integrated Health and Microfinance in India, Volume III: Banking on Health. Washington, DC: RESULTS Educational Fund 
Figure 7: Timeline of Health Finance (HF) Innovations

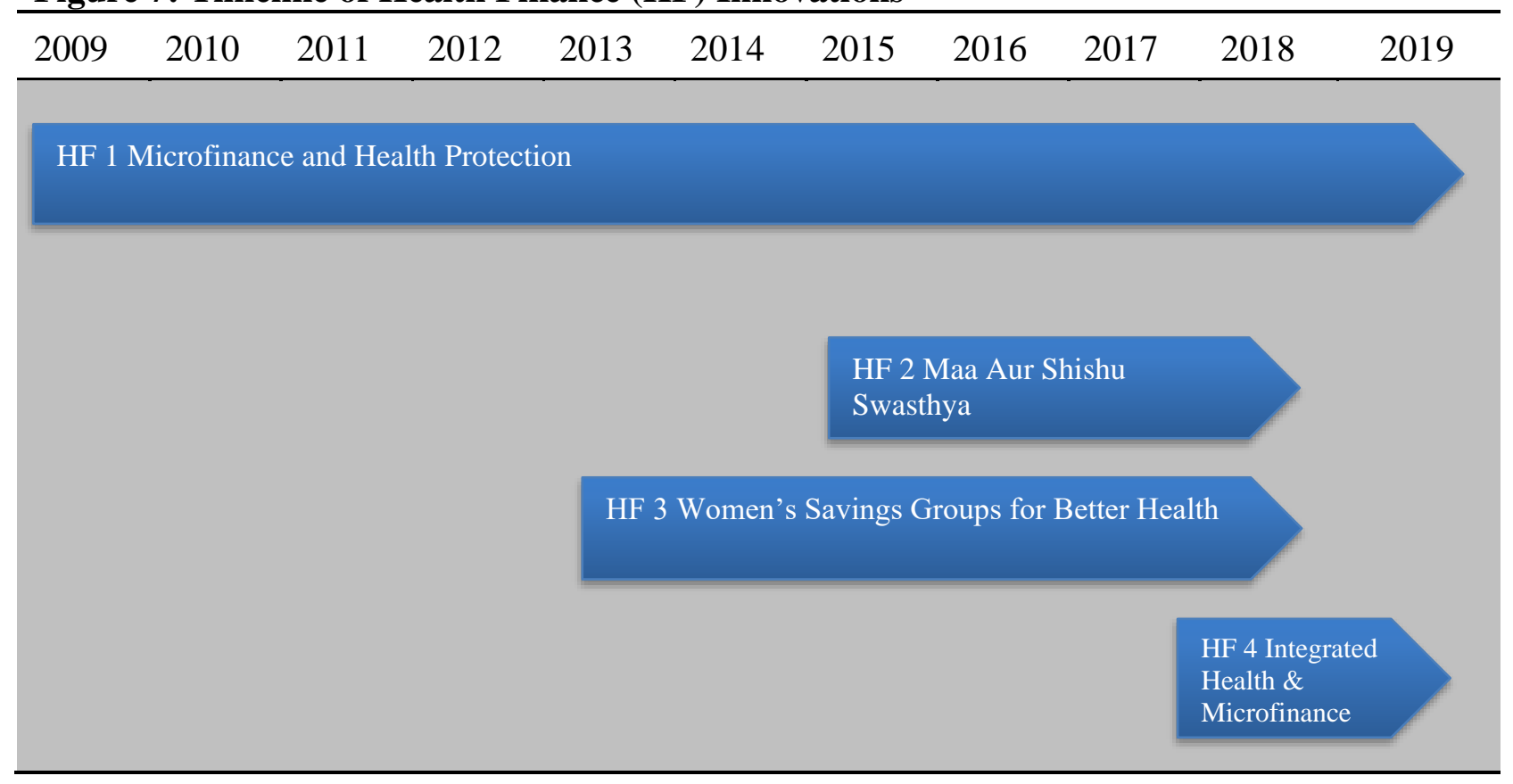

6.2.1 Microfinance and Health Protection, 2006 - 2019

Sensing: Grameen Foundation found that farmers often could not operate effectively because of health issues even when they had received loans to finance their efforts. Field agents needed to connect farmers with health financial services providers and access to health care providers when they encountered health emergencies. Grameen explored opportunities within its internal and external resources to address these needs.

Seizing: In January 2006, Grameen Foundation launched the Microfinance and Health Protection initiative with funding from the Bill \& Melinda Gates Foundation. The program promotes and supports good health through an integrated set of services that include health and nutrition education, health financing and micro insurance, linkages to health providers, and access to health products. The success of this integrated approach to health reached poor women 
and their families through a network of financial service providers and others. Amelia, Program

Manager for Latin America comments:

"Our microfinance and health protection was first piloted in five countries, it's going to be a little over 10 years now, so looking at health financing, health education and health linkages, and really bringing those three pieces together as integrated is one example where we've been able to both scale and efficiently replicate in context that may have different cultural issues going on, but we've been able to adjust those tools so that it works."

Transforming: Women's savings groups provided the best medium through which health education and health finance were conducted. Through this peer network platform, field agents disseminated information about saving additional funds for health emergencies. Building clients' ability to pay out of pocket expense minimized default rate on the initial MF loan, a lesson Grameen Foundation learned from Freedom from Hunger.

Outcomes: At the end of December 2012, 25 MFIs and self-help promoting institutions had provided products and services to 2.3 million clients (about 11.5 million people, including family members) across ten countries. Bobbi, Director of Research who has worked for Freedom from Hunger and Grameen Foundation comments:

"So with freedom from hunger, we were really focused on village banking, savings groups and what we called integrated services. So we looked at savings groups in village banks as well as the impact of integrating health with microfinance in general. So even though we did financial education, health was just one particular area where we spent a lot of time trying to demonstrate that microfinance institutions could maintain their core value proposition of financial services and do additional good in health. Arguing that a healthy client makes a healthy portfolio - which is pretty much one of the biggest risks microfinance clients face."

\subsubsection{Maa Aur Shishu Swasthya (MASS), 2015 - 2018}

Sensing: Maternal and child health is a key focus for Grameen Foundation. A study conducted in the Bandhan region of India found acute cases of anemia among women and children, and worse, only $30 \%$ of the population tested for it, indicating that $44 \%$ of the women 
suffered from severe anemia and that children were less likely to be tested or diagnosed ${ }^{47}$. Field agents in India needed to link mothers with health and financial services as well as education. Existing networks of finance and health providers offered Grameen Foundation opportunities to explore solutions to address this need.

Seizing: In 2015, Grameen Foundation partnered with RESULTS, a US-based educational fund, and two of the largest MFIs in India: Aikyatan Development Society and Bandhan-Konnagar ${ }^{48}$ to launch the Maa aur Shishu Swasthya (MASS, or Mother and Child Health) project. The program's main aim was to build awareness on how to prevent anemia among mothers and children by integrating the delivery of health education, financial services, and linkages to health care providers.

Transforming: MASS was one of the largest and most successful HF programs at Grameen Foundation. By adopting the Women's Savings group model from West Africa, Grameen leveraged women self-help groups (SHGs) in India as agents. Through SHGs, they deployed a grassroots partnership of community health workers who advised their peers on health education and ways to access health linkages to local clinics. SHGs worked closely with the Gram Panchayat to ensure the cooperation of government frontline health workers when extending the facilities to which the women and children were entitled. On how MASS was implemented, Bobbi, Director of Research comments:

"By replicating Grameen Foundation's Savings for Change methodology for health savings in West Africa, each group of women borrowers, referred to as Self Help Groups decides on its weekly savings amount and interest. SHGs save separately for health in addition to their regular activities giving them access to health loans and an annual savings payout earmarked for health."

${ }^{47}$ Ibid

${ }^{48}$ Rogers S, Rao DSK, Satish P, Saha S. (2018). Integrated Health and Microfinance in India, Banking on Health. Washington, DC: RESULTS Educational Fund. 
Outcomes: 556, 541 women, girls and their households were reached with health education. 122,356 women and girls were linked to health care services and providers, 16,000 women from SHGs saved separately for health in addition to their regular SHG activities, giving them access to health loans and an annual savings payout earmarked for health expenses ${ }^{49}$. Two million Indian Rupees were collected for health savings $(\$ 28,032)$, and a group-based network of 51 health providers, microfinance, and government organizations became members of the community of practice for health and microfinance (COPHAM) that was established by MASS. Lastly, six financial services providers across four states in India reached 170,000 women and adolescent girls through this group based network ${ }^{50}$. Amelia, Program Manager for Latin America comments:

"Women are able to access those funds when needed the most. And so that was really an interesting integration because it was working with a lot of different levels of doctors and doctors assistance, pharmacies, credit card companies as well as MFIs to kind of work on the chain so that clients had access, they knew about it, and they had advocates within the system to help them take better care of their health."

\subsubsection{Women's Savings Groups for Better Health, 2013 - 2018}

Sensing: Rural women who are part of the savings groups in Benin lacked information on reproductive education and planning. Community health agents and women's savings groups needed shared knowledge on family planning, how to save for health and how access to health services. Opportunities existed within the Grameen Foundation for the quick dissemination of such information by working through the existing organized groups like the savings group to which most women in rural Benin belonged.

${ }^{49}$ Ibid

50 Ibid 
Seizing: Since 2013, Freedom from Hunger, now Grameen Foundation, worked in partnership with two local non-governmental organization (NGO) partners in Bénin -Association pour la Promotion de l'Homme, la Protection de l'Environnement pour un Développement Durable and Femmes Actrices de Développement Communautaire ${ }^{51}$ to design a Health Savings innovation program. Training local NGO's volunteer community agents who, in turn, delivered family planning education, along with the health savings methodology and health provider linkage information to women's saving groups. Women received health cards that were linked to health service providers, pharmacies, and MFIs. Amelia, Program Manager for Latin America comments:

"The health credit card was one of them. And the other one was a telemedicine project, which was linking rural doctors to more specialists so that clients in remote areas wouldn't necessarily have to travel. And they would be able to get basically a second opinion from a specialist. They could submit lab work and photos to the generalist for an evaluation of the situation and get a second opinion on whether it was in fact necessary to come into one of the bigger cities for specialist care."

Transforming: Women who participated in the Health Savings program reported interest in seeking information about family planning products and services. In response to the enormous unmet need for family planning in the region, the two NGO partners integrated Grameen's family planning approach to their savings group program, this strengthened Bénin's national family planning strategy and contributed to achieving their long-term goal of increasing contraceptive prevalence rate among women.

Outcomes: This program introduced and trained partners on Grameen's savings group methodology. It subsequently planned and developed a health intervention package that

${ }^{51}$ Alison Burgon Bardsley, Bobbi Gray, Cassie Chandler, Nadege Gbaguidi. Healthy Savings for Better Reproductive Health in Bénin, February 2019 Report. 
improved access to health services for 3,000 savings group members and their families who by December 2018 had collected and saved 29,514,800 West African Franc CFA* an equivalent of $\$ 51,152$.

6.2.4 Integrated Health and Microfinance, 2018 - 2019

Sensing: In 2018, the Indian government began a nationwide campaign to provide affordable health care for all through the Universal Health Care initiative. Community health workers in India needed to connect the poor in rural areas to health education, financial services providers, and affordable health services with participating providers in the recently proposed government Universal Health Care initiative. Widespread diffusion of mobile technology afforded an opportunity to develop connectivity apps to address the health and finance needs of the poor in India.

Seizing: Grameen and two other organizations believed that positioning integration of health and MF would supplement the government's efforts and pave the way to universal health coverage. A press release on August 15, 2018, in the Times of India stated Prime Minister Narendra Modi's announcement of his government's decision to launch Ayushman Bharat (Healthy India), a universal health coverage scheme. Quoting the Honorable Prime Minister's speech during the Independence Day address to the nation, Modi stated, "It is high time we

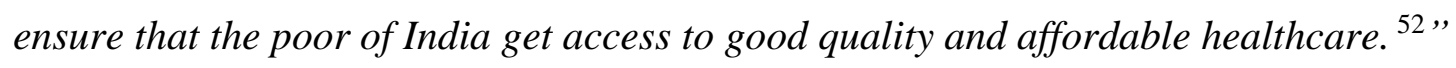
Ayushman Bharat is reported to reach 500 million Indians, targeting rural families and certain categories of urban workers according to the Times of India, 2018.

Transforming: Attaining the above goal is a bold step by the Indian government, one that would require resources and partnerships such as the community of microfinance and health

52 Times of India, August 15, 2018 
services network of which Grameen Foundation was a member. Given the current state of the health care system in India, attainment of universal health care would benefit from Grameen Foundation's model, particularly the leveraging of savings and self-help groups as a potential platform to deliver health-related education, financing, and linkages to providers. Quote from the Times of India:

"This exciting announcement comes at a time when the Government of India has a mammoth challenge. An ever-increasing population, low government health spending and a dismal health infrastructure, including unsafe drinking water and poor sanitation, strain its healthcare system. The fragmented services provided by private health practitioners compounded by the poorly staffed and equipped rural clinics have created a rural-urban divide, perpetuating inequity in accessing health services."

Outcomes: By the timeline of this study, this initiative was ongoing and no outcomes had been reported with regards to Grameen Foundation's involvement with the community of practice for health and microfinance network of providers.

\subsubsection{Summary of Health Finance Innovations}

Sensing: Innovation in HF at Grameen Foundation was triggered by assessing the health needs of the poor, followed by identifying the gaps in the provision of health education, health protection, and financial services at country levels. Consequently, opportunities to fill those gaps were explored by critically looking at technological resources that existed internally and externally.

Seizing: Implementation of innovation in HF was achieved in two ways; first, through an integrated approach where linkages were built among service providers including health, insurance pharmacies, and MFIs. Second, Grameen Foundation designed loan and savings products for clients to access health services as illustrated in Table 6. The challenge Grameen Foundation faced was in making a business case to MFIs to provide two separate loans: a typical 
MFI and a health loan where the latter came with the risk of nonpayment or delayed payment when clients faced sustained periods of health emergencies. Bobby, Director of Research comments:

"So when we designed health finance we wanted to protect the MFIs and to make sure that they gave favorable interest rates, which means they were going to make the interest rate lower than a typical microenterprise loan because it's going to take clients longer to repay because they're probably sick; leaving them with two loans at the same time. So they decided they'd give a lower interest rate but they wanted proof that the money wasn't being used for anything else, they didn't want it to cannibalize their other products. We made a Business case to health care providers and insurance providers to ensure clients have the Health funds/loans and savings and insurance for emergency health care access and that they don't end up with two loans which may be hard to repay."

Lastly, on how Grameen Foundation implemented health savings through raising awareness among the already existing savings groups, Bobby, Director of Research comments:

"We've used savings groups to provide health savings first for the basic fund and then they'll save again for a health fund. They have payouts and its just kind of repeated the same way that they would do for the basic fund."

Transforming: Whereas HF innovation outcomes proved to be transformative in promoting greater women's empowerment in household decision-making concerning family health and financial matters, most importantly, it ensured that poor health did not impede the economic advancement of low-income families. Unfortunately, trying to change people's behavior to save for health expenses had challenges. Bobby, Director of Research comments:

"We found that people respond to health needs like an emergency regardless of how small of a health issue it is. The challenge is in creating a commitment device for households to make sure that they actually save for health and they only use that money for health."

Perhaps an ongoing challenge Grameen Foundation faced in designing innovative products for health financing was that HF donors were not as forthcoming compared to Agriculture Finance donors. Bobby, Director of Research comments: 
"There hasn't been a lot of appetite interestingly on health finance because if you go to your health donors, they don't see this as something they want to fund because they really want to fund health systems strengthening. There's probably a lot more appetite for agriculture financing frankly than health financing.

Outcomes: India's MASS project benefited over 500,000 women and children who obtained health services, training, and health finance; this proved the effectiveness of Grameen Foundation's integrated approach to combining health microfinance, health protection through encouraging emergency savings, health education and connecting rural clients to a network of healthcare providers and pharmacies. Other outcomes included microfinance and health protection products and services, which were provided by 25 MFIs to self-help promoting institutions and reached 2.3 million clients, an estimate of 11.5 million people, including family members across ten countries. In Benin, 3,000 savings groups received access to health loans and an annual savings payout earmarked for health expenses. After a few years, women savings groups had collected 29,514,800 $\mathrm{CFA}^{53}$ an equivalent of $2018(\$ 51,152)$.

${ }^{53} \mathrm{CFA}$ : West African Franc is the currency of Benin 
Table 6: Summary of Health Finance (HF) Innovations (2009 - 2019)

\begin{tabular}{|c|c|c|c|c|c|}
\hline \multirow{2}{*}{ Activity } & \multirow{2}{*}{ Ordinary Capability } & \multicolumn{4}{|c|}{ Dynamic Capability } \\
\hline & & Sense & Seize & Transform & Outcomes \\
\hline $\begin{array}{l}\text { Microfinance and } \\
\text { Health Protection } \\
2006-2019\end{array}$ & $\begin{array}{l}\text { Increasing access to } \\
\text { health education, health } \\
\text { protection, and financial } \\
\text { services for poor women } \\
\text { and their families. }\end{array}$ & $\begin{array}{l}\text { Field agents need to } \\
\text { connect farmers with } \\
\text { financial access and } \\
\text { health providers during } \\
\text { health emergencies. } \\
\text { Widespread diffusion of } \\
\text { mobile technology affords } \\
\text { opportunity to develop } \\
\text { connectivity apps.. }\end{array}$ & $\begin{array}{l}\text { Poor families were } \\
\text { reached through a } \\
\text { network of Financial } \\
\text { Health Service } \\
\text { Providers. } \\
\text { Supported by Bill and } \\
\text { Melinda Gates } \\
\text { Foundation. MF and } \\
\text { Health became the HF } \\
\text { flagship activity. }\end{array}$ & $\begin{array}{l}\text { The integration of MF, } \\
\text { health, and protection } \\
\text { gave clients the ability } \\
\text { to pay out of pocket } \\
\text { expenses, minimized } \\
\text { the default on their } \\
\text { initial MF loans and } \\
\text { improved education on } \\
\text { health issues. }\end{array}$ & $\begin{array}{l}\text { Microfinance and } \\
\text { health protection } \\
\text { products and services } \\
\text { were provided by } 25 \\
\text { MFIs who reached } \\
2.3 \text { million clients (an } \\
\text { estimate of } 11.5 \\
\text { million people, } \\
\text { including family } \\
\text { members) across ten } \\
\text { countries. }\end{array}$ \\
\hline $\begin{array}{l}\text { Maa Aur Shishu } \\
\text { Swasthya (MASS) } \\
2015 \text { - } 2018\end{array}$ & $\begin{array}{l}\text { Increasing access to } \\
\text { health education, health } \\
\text { protection, and financial } \\
\text { services for poor women } \\
\text { and their families. }\end{array}$ & $\begin{array}{l}\text { Rural women in India } \\
\text { need access to finance in } \\
\text { order to access health } \\
\text { services and health } \\
\text { information. } \\
\text { Field agents in India need } \\
\text { to connect rural women } \\
\text { with financial health and } \\
\text { educational information. } \\
\text { Widespread diffusion of } \\
\text { mobile technology affords } \\
\text { opportunity to develop } \\
\text { connectivity apps linking } \\
\text { financial providers and } \\
\text { health providers. }\end{array}$ & $\begin{array}{l}\text { Volunteer field agents } \\
\text { from the Self Help } \\
\text { Groups in India } \\
\text { implemented MASS } \\
\text { Grameen Foundation } \\
\text { partnered with } 2 \text { of the } \\
\text { largest MFIs to provide an } \\
\text { integrated package of } \\
\text { financial services, health } \\
\text { financing, health } \\
\text { education, and linkages to } \\
\text { formal health providers to } \\
\text { develop MASS. }\end{array}$ & $\begin{array}{l}\text { The Community of } \\
\text { Practice for Health and } \\
\text { Microfinance, a group } \\
\text { based on the } \\
\text { integration of health } \\
\text { and MF resulted out of } \\
\text { MASS with over } 51 \\
\text { partners including } \\
\text { Grameen Foundation. } \\
\text { MASS was one of } \\
\text { Grameen Foundations } \\
\text { largest Health Finance } \\
\text { activity. }\end{array}$ & $\begin{array}{l}556,541 \text { women, } \\
\text { girls and their } \\
\text { households were } \\
\text { reached with health } \\
\text { education. } \\
122,356 \text { women and } \\
\text { girls were linked to } \\
\text { health care services } \\
\text { and providers. } \\
16,000 \text { women from } \\
\text { SHGs saved } \\
\text { separately for health } \\
\text { in addition to their } \\
\text { regular SHG } \\
\text { activities. } \\
2 \text { million Indian } \\
\text { Rupees was collected } \\
\text { for health savings } \\
\text { (\$28,032). } \\
\text { Six financial services } \\
\text { partners across four }\end{array}$ \\
\hline
\end{tabular}




\begin{tabular}{|c|c|c|c|c|c|}
\hline & & & & & $\begin{array}{l}\text { states in India } \\
\text { reached } 170,000 \\
\text { women and } \\
\text { adolescent girls. }\end{array}$ \\
\hline $\begin{array}{l}\text { Women's Savings } \\
\text { Groups for Better } \\
\text { Health } \\
2013-2018\end{array}$ & $\begin{array}{l}\text { Increasing access to } \\
\text { health education, health } \\
\text { protection, and financial } \\
\text { services for poor women } \\
\text { and their families. }\end{array}$ & $\begin{array}{l}\text { Community health agents } \\
\text { and women savings } \\
\text { groups in Benin need } \\
\text { information on family } \\
\text { planning, on how to save } \\
\text { for health and on how to } \\
\text { access health services. } \\
\text { Opportunities to provide } \\
\text { linkages among health } \\
\text { between health and } \\
\text { financial providers could } \\
\text { be explored. }\end{array}$ & $\begin{array}{l}\text { Community health agents } \\
\text { delivered family planning } \\
\text { education, along with } \\
\text { health savings } \\
\text { methodology, health } \\
\text { information, and provided } \\
\text { health linkages to } \\
\text { women's savings groups. } \\
\text { Grameen Foundation } \\
\text { partnered with two local } \\
\text { NGOs to design linkages } \\
\text { to public and private } \\
\text { health providers who } \\
\text { introduced and trained } \\
\text { partners on Grameen's } \\
\text { savings groups. }\end{array}$ & $\begin{array}{l}\text { Improved access to } \\
\text { reproductive health } \\
\text { services for savings } \\
\text { groups members and } \\
\text { families } \\
\text { The two NGO partners } \\
\text { integrated Grameen's } \\
\text { family planning } \\
\text { approach to their } \\
\text { savings groups } \\
\text { program that } \\
\text { strengthened Bénin's } \\
\text { national family } \\
\text { planning strategy. }\end{array}$ & $\begin{array}{l}3,000 \text { savings groups } \\
\text { received access to } \\
\text { health loans and } \\
\text { annual savings } \\
\text { payout earmarked for } \\
\text { health expenses. } \\
29,514,800 \mathrm{CFA} * \\
\text { was collected for } \\
\text { health savings by } \\
\text { December } 2018 \\
(\$ 51,152)\end{array}$ \\
\hline $\begin{array}{l}\text { Integrated Health } \\
\text { and Microfinance, } \\
\text { India } 2018-2019\end{array}$ & $\begin{array}{l}\text { Increasing access to } \\
\text { health education, health } \\
\text { protection, and financial } \\
\text { services for poor women } \\
\text { and their families. }\end{array}$ & $\begin{array}{l}\text { Community Health } \\
\text { workers in India need to } \\
\text { connect the poor in rural } \\
\text { areas with health } \\
\text { education and health } \\
\text { savings services. } \\
\text { Widespread diffusion of } \\
\text { mobile technology affords } \\
\text { opportunity to develop } \\
\text { connectivity apps. to } \\
\text { address the health and } \\
\text { finance needs of the poor. }\end{array}$ & $\begin{array}{l}\text { Grameen Foundation } \\
\text { recently partnered with } \\
\text { the government of India } \\
\text { to create programs that } \\
\text { integrate health and } \\
\text { microfinance. }\end{array}$ & - & - \\
\hline
\end{tabular}

*\$1 Dollar (USD) = 577 West African CFA franc as of February 2019 


\section{VI.3 Innovation Program III: Digital Finance (DF)}

With close to two billion people globally who lack access to formal financial services according to the World Bank ${ }^{54}$, Grameen Foundation played a critical role as an innovator in the field of financial services backed by nearly three decades of bridging the gaps in financial inclusion by designing digital financial solutions that MFIs delivered to the poor ${ }^{55}$ who lived in remote rural communities. Grameen Foundation recognized that the gap in access was even wider for rural women who were mainly illiterate; therefore, it designed digital financial solutions that were user friendly, and integrated ${ }^{\mathbf{5 6}}$ financial access with digital literacy. With expertise in creating financial linkages, Grameen Foundation helped the poor generate income, build assets, smooth consumption, and manage risks. Phrabat, Country Director at Grameen Foundation India comments:

"So our starting point is the product features itself, we ask: what kind of features does this person require? The other is about knowledge and awareness. The second is how to make it available? This is where the customer education becomes important. And the third part is how will the clients access these products, and this is where you work on the channels. So it takes financial education and digital literacy."

Figure 8 (below) shows a timeline of some of the key DF innovation activities. We applied Dynamic Capabilities theory on each of these activities showing how Grameen Foundation innovation DF activities from ordinary capabilities through sensing, seizing, and transforming.

\footnotetext{
54 www.worldbank.org

${ }^{55}$ Grameen Foundation Mobile Money Capacity Statement Report

${ }^{56}$ Ibid
} 
Figure 8: Timeline of Digital Finance (DF) Innovations

\begin{tabular}{lllllllllll}
\hline 2009 & 2010 & 2011 & 2012 & 2013 & 2014 & 2015 & 2016 & 2017 & 2018 & 2019
\end{tabular}

\section{DF 1 Airtel Weza}

DF 2 Digitizing financial Inclusion Via Education

\section{DF 3 Community Agent}

Networks

\section{DF 4 Accelerator Digitizing Financial}

\subsubsection{Airtel Weza, 2012 - 2016}

Sensing: In rural Uganda, as elsewhere in Africa, digital solutions proved to be the best means for delivering financial solutions targeted for poor women and men. However, rural field agents still struggle with connectivity challenges such as inconsistent network coverage, sparse populations, and liquidity challenges. Grameen needed to explore alternative delivery channels to enable last mile access to financial services. Widespread use of mobile technology in Uganda offered an opportunity for Grameen Foundation to explore digital solutions.

Seizing: In 2012, Grameen Foundation in Uganda partnered with Airtel Uganda, a mobile communication company, to design Airtel Weza, a digital mobile money wallet that allowed savings groups to store their cash on a phone as mobile money as opposed to the lock boxes. ${ }^{57}$ To train clients on the use of Airtel Weza, Grameen partnered with the global nonprofit FHI 360 to expand the number of Airtel agents who served savings groups in remote areas. 
Airtel agents deployed the Airtel Weza app on customer cell phones the app provided grouplevel security, since it required three members of each group to enter individual pin numbers for cash withdrawal approval in addition to all group customers receiving SMS confirmation messages for each transaction.

Transforming: At the 2016 Digital Impact Awards for Africa, Airtel Weza - Uganda was recognized as "Best Financial Inclusion Initiative."58 The award proved that Grameen's global engagement in digital financial services supported the implementation of solutions led by banks; Mobile Network Operators, and third-party providers who pushed the reach of financial services to rural clients, significantly contributed to improving financial inclusion.

Outcomes: Thousands of smallholder rural households from 200 saving groups participated in Airtel Weza. Users reported increased security, transparency, and less misuse of funds. ${ }^{59}$ Judith, Regional Director, Grameen Foundation East Africa comments:

"Grameen Foundation developed an award-winning mobile virtual wallet allowing over 200 groups of Ugandans to collectively save fixed amounts, while experiencing increased security and transparency in their funds."

\subsubsection{Digital Financial Inclusion Via Education (DIVE), 2012 - 2019}

Sensing: In India, Grameen Foundation sensed that for financial inclusion to improve among rural populations who were illiterate, field agents and rural clients needed a platform for continued knowledge sharing on financial access and literacy. Technological opportunities within Grameen existed to leverage training on financial literacy as well as access to financial services.

58 Ibid

59 Ibid 
Seizing: In 2012, Grameen Foundation India designed Digital Financial Inclusion via Education ${ }^{60}$ (DIVE), a digital financial platform supported by Citigroup Global Markets and implemented with technical collaboration by the National Payments Corporation of India, as well as several local partners. To implement DIVE, Grameen Foundation trained and used digitally empowered field agents, mostly females who took financial services directly to women clients. Over 100 Grameen ${ }^{61}$ Mitras translated as "Friend of the Village" (in Hindi) acted as digital financial service agents who trained their neighbors in financial literacy, connected them to vital services via client's mobile phones that also connected through the government's digital platforms. Phrabat, Country Director, Grameen Foundation India comments:

"So far we have set up an agent network, we call the Grameen Mitra, in Hindi it means a friend, it also means a villager. A Mitra is often a woman, recruited from the local community and we give them financial digital knowledge and financial literacy. Also, we train them on how to be a successful agent, on sales techniques, communication, problem solving, all those aspects."

Transforming: The transformation of the Mitras was attributed to the fact that they were incentivized, and they gained new skills in digital and financial literacy, all of which increased their social capital in the communities. Gaurav Chakraverty, Director of Program Strategy at Grameen Foundation India comments:

"The Mitras are transforming their own lives by learning new skills, generating an additional stream of income, and gaining greater financial independence."

Outcomes: Each Mitra serviced an estimated 1,500 households and benefitted up to 250,000 people with first time or improved access to savings, insurance, utility bill payments,

${ }^{60}$ Ibid

61 Ibid 
and government programs like pensions. By January 2019, the Mitras had facilitated transactions worth more than $2.6 \mathrm{~m}$ Indian Rupees is equivalent to $(\$ 36,590)^{62}$

\subsubsection{Community Agent Network (CAN), 2016 - 2019}

Sensing: The Philippines unique geography mainly comprised of islands pose an additional obstacle for field workers and communities in accessing financial services. Technological opportunities within Grameen Foundation exist to improve connectivity and enable the training of the rural poor on how to access financial services

Seizing: Grameen's responded to this challenge by partnering with two of the largest FinTech providers: Action.Able, Inc., and Payswitch Fintech Ventures to design a digital financial services platform - Panalo, that enabled digital transactions ${ }^{63}$. Panola was designed as a digital "point of service" that connected directly over any mobile network, bank, government agencies, utility companies and other businesses. Grameen's implementation approach also included building a Community Agent Network (CAN) of female shop owners ${ }^{64}$ and distributors referred to as "Sari Saris" who served the financial needs of women and the poor by visiting them from household to household.

Through CAN, Sari Saris became the catalyst for last mile financial service delivery to the poor. To successfully implement CAN, Grameen Foundation received funding from the JP Morgan Chase Foundation to create a network of 1,900 agents, 75 percent of whom were women. Sari Saris were empowered with tablets that came equipped with the digital financial services platform (Panola), which they used to reach rural clients directly on their phones and connected them to banks, utility companies, government agencies, and other businesses. Using

\footnotetext{
62 Ibid

${ }^{63}$ Ibid

64 Ibid
} 
female agents demonstrated Grameen Foundation's empowering ecosystem of how they

integrated gender equity into DF innovation. Bobbi, Director of Research comments:

"I think when we talk about women agent networks for financial services for example, we are thinking of the fact that women agents are the peer support that other women need to gain access to financial services. They work in rural communities, they're the ones that can promote and talk to other women about financial services, they can help facilitate their access to digital payments or depositing money in a savings account and so that's the linkage to the formal financial services that they're helping to facilitate."

Transforming: Sari Sari store operators became the point of contact for payments and services; they helped their customers with transaction payments, money transfers, and with depositing money to digital accounts. This proximity in access reduced hours and money that people previously spent traveling to distant bank branches. Lastly, Sari Saris received incentives for each transaction, hence increasing their economic empowerment.

Outcomes: In the first two years of operations between 2016 and $2017,{ }^{65} \mathrm{CAN}$ agents facilitated more than 4.3 million transactions valued at 1.3 billion Philippine Pesos $(\$ 24.9 \mathrm{M})$. Sustainability was built into the program as both the agents and the technology companies got a small fee for each transaction; banks got new customers, and both clients and financial services providers saved time and money as a result the efficiencies of digital finance. 6.3.4 Accelerator Digitizing Financial Institutions, 2012 - 2016

Sensing: Uganda has a big shortage of bank branches and ATMs. According to Grameen Foundation, in 2012, there was less than one financial services access point for every 20,000 people nationally, and fewer still in rural areas. ${ }^{66}$ It is costly for field agents and rural clients to travel long distances to access financial services. Widespread use of mobile technology in

${ }^{65}$ www.grameenfoundation.org

${ }^{66}$ Grameen Foundation Mobile Money Capacity Statement Report 
Uganda offered an opportunity for Grameen Foundation to explore digital solutions to address the need.

Seizing: Grameen Foundation seized the opportunity to build financial linkages with the following partners: two financial service providers; Centenary Bank and Pride Microfinance Ltd. a fully owned government financial institution; a Mobile Network Operator, AIRTEL; and, a third-party technical platform, Cellulant enabled Centenary Bank and Pride Bank to use the mobile money ecosystem as a delivery channel for financial services to the poor in rural Uganda. ${ }^{67}$ The integration of financial services providers and mobile network operators via a third-party platform ${ }^{68}$ enabled clients to access their Centenary Bank or Pride Bank accounts at any mobile money agent location via bank-to-mobile or mobile-to-bank transactions. Grameen Foundation oversaw the integration and provided technical assistance to the two financial services providers and made changes that were necessary to support the new offering. Grameen's support in the integration was to train bank employees on new customer base and channel; it ensured appropriate marketing to the poor and worked with the risk department to build their preparedness for Digital Financial Services (DFS). ${ }^{69}$

Transforming: As was the case in the Philippines, clients no longer had to travel long and sometimes hazardous trips to the bank. Having this service enabled fast, flexible, secure, and remote transactions for any of Centenary Bank and Pride Banks' clients. Banks and mobile network operators acquired new clients.

Outcomes: While the Grameen Foundation's role ended, the channels and products developed still live on as sustainable digital financial solutions that truly serve the rural poor. As

\footnotetext{
${ }^{67}$ Ibid

${ }^{68}$ Ibid

69 Ibid
} 
pointed out, this partnership attracted new rural customers every day. For example, by October 2016, the system had served more than 170,000 rural customers who now had access to their accounts over this digital channel, and the numbers were projected to grow by an additional 10,000 clients each month. ${ }^{70}$

\subsubsection{Summary of DF Innovations}

Sensing: During the 2019 Nobel lecture at Harvard following the events of his Nobel Economic Prize together with Dr. Banerjee and Dr. Duflo, Dr. Michael Kremer stated that "Scaling access to financial services has been made easier in the last decade with an uptake of cell phones in most middle and low income countries," ${ }^{71}$ Grameen Foundation sensed that in order to improve financial inclusion for smallholder farmers who live in remote areas, it had to first overcome major challenges of poor connectivity that prevented them from accessing financial products, services, and financial literacy. However, Grameen observed that widespread use of mobile technology in the middle to low income countries provided opportunities to bridge the gaps in connectivity.

Seizing: Grameen Foundation seized the uptake of mobile phones by designing cloud based mobile apps and leveraged the success of mobile money platforms like Mpesa in Kenya and Mobile Network Operators like Airtel in Uganda to deploy such apps at scale. They implemented by building financial linkages with partners such as financial service agents (Sari Saris in the Philippines and Mitras in India) who were trained on the use of digital services and, in turn, trained others on how to access financial services in their communities. And on how they orchestrated partnerships Christian, Director of Financial Inclusion comments:

${ }^{70} \mathrm{Ibid}$

${ }^{71} \mathrm{https}: / /$ youtu.be/hOTHeNZU_JQ 
"What we do is to work with partners based on the needs of their markets, their structure and based on their mission. We develop products and services that fit their clients' needs. These partners include mainly financial institutions, banks, microfinance institutions, mobile network operators and FinTech. And so in terms of products, we are talking about loans (general and agricultural), savings (short term and long term), insurance and so on."

Transforming: Scale in digital finance was achieved through a multi-sectorial approach whereby Grameen Foundation collaborated with financial services providers, mobile networks operators, and others according to context. Christian, Director of Financial Inclusion comments,

"In India and the Philippines, Grameen Foundation collaborated with partners to recruit, train, equip and manage. In Africa, Grameen Foundation has worked with banks and microfinance institutions to link with mobile network operators to use their network of agents as access points for bank accounts."

Grameen Foundation's unique approach to DF innovation yielded unintended positive consequences for its partners as they tapped into a rural clientele ${ }^{72}$ that hitherto hadn't been their target market. The use of female financial agents, Sari Saris in the Philippines and the Mitras in India, who acquired new skills in financial literacy, were incentivized. They trained others and, in turn, created micro entrepreneurs. These women had "social capital in the community" comments Julian, Technical Advisor for Agriculture Innovation, who further comments: "CAN is one of the most transformative DF innovation when it comes to improving financial inclusion."

Outcomes: 12 million poor people and their families gained better access to microloans, savings accounts, money transfers, bill payments, insurance, and other financial services $^{73}$ as a direct result of Grameen Foundation's DF innovations.

72 Ibid

${ }^{73}$ www.grameenfoundation.org 
Table 7: Summary of Digital Finance (DF) Innovations (2009 - 2019)

\begin{tabular}{|c|c|c|c|c|c|}
\hline \multirow{2}{*}{ Activity } & \multirow{2}{*}{ Ordinary Capability } & \multicolumn{4}{|c|}{ Dynamic Capability } \\
\hline & & Sense & Seize & Transform & Outcomes \\
\hline $\begin{array}{l}\text { Airtel Weza } \\
2012-2016\end{array}$ & $\begin{array}{l}\text { Improving financial } \\
\text { inclusion by delivering } \\
\text { last mile access of } \\
\text { financial products, } \\
\text { services, and financial } \\
\text { literacy to smallholder } \\
\text { farmers in remote } \\
\text { areas. }\end{array}$ & $\begin{array}{l}\text { Field agents in Uganda } \\
\text { need to provide farmers } \\
\text { living in remote areas } \\
\text { with access to financial } \\
\text { products and services. } \\
\text { Widespread use of } \\
\text { mobile technology and } \\
\text { digital platforms offer } \\
\text { opportunity to meet this } \\
\text { need. }\end{array}$ & $\begin{array}{l}\text { Grameen partnered with } \\
\text { a global nonprofit FHI } \\
360 \text { to expand the } \\
\text { number of Airtel agents } \\
\text { who served savings } \\
\text { groups in remote areas. } \\
\text { Grameen partnered with } \\
\text { Airtel Weza to design a } \\
\text { digital mobile money } \\
\text { wallet that allowed } \\
\text { savings groups to store } \\
\text { their cash on their } \\
\text { phones as mobile money. }\end{array}$ & $\begin{array}{l}\text { Airtel Weza platform } \\
\text { provided improved } \\
\text { security features for } \\
\text { saving groups. } \\
\text { In 2016, Airtel Weza } \\
\text { won the Digital Impact } \\
\text { Award in Africa for } \\
\text { "Best Financial } \\
\text { Inclusion Initiative". }\end{array}$ & $\begin{array}{l}\text { More than } 200 \text { groups } \\
\text { comprised of thousands of } \\
\text { women members } \\
\text { participated in Airtel } \\
\text { Weza. }\end{array}$ \\
\hline $\begin{array}{l}\text { Digital Financial } \\
\text { Inclusion Via } \\
\text { Education (DIVE) } \\
2018-\mathbf{2 0 2 0}\end{array}$ & $\begin{array}{l}\text { Improving financial } \\
\text { inclusion by delivering } \\
\text { last mile access of } \\
\text { financial products, } \\
\text { services, and financial } \\
\text { literacy to smallholder } \\
\text { farmers in remote } \\
\text { areas. }\end{array}$ & $\begin{array}{l}\text { Field agents in India } \\
\text { need to train rural } \\
\text { populations on the use } \\
\text { and access to financial } \\
\text { products, services as } \\
\text { well as financial literacy. } \\
\text { Widespread use of } \\
\text { mobile technology and } \\
\text { digital platforms offer } \\
\text { opportunity to meet this } \\
\text { need. }\end{array}$ & $\begin{array}{l}\text { Mitras acted as digital } \\
\text { financial service agents } \\
\text { by providing their } \\
\text { neighbors training in } \\
\text { financial literacy and } \\
\text { connecting them to vital } \\
\text { financial services. } \\
\text { Grameen designed } \\
\text { Digital Financial } \\
\text { Inclusion via Education } \\
74 \text { (DIVE) a digital } \\
\text { financial platform } \\
\text { supported by Citigroup } \\
\text { and National Payments } \\
\text { Corporation of India. }\end{array}$ & $\begin{array}{l}\text { Through DIVE, } \\
\text { thousands of rural } \\
\text { clients connected to } \\
\text { first-time or improved } \\
\text { access to savings, } \\
\text { insurance, utility bill } \\
\text { payments, and } \\
\text { government programs } \\
\text { like pensions. }\end{array}$ & $\begin{array}{l}\text { By January } 2019, \text { Mitras } \\
\text { had facilitated } \\
\text { transactions worth more } \\
\text { than } 2.6 \mathrm{~m} \text { Indian Rupees } \\
\text { equivalent to } \$ 36,590 \\
\text { Over } 100 \text { Mitras serviced } \\
\text { an estimated } 1,500 \\
\text { households and benefitted } \\
\text { up to } 250,000 \text { rural } \\
\text { households. }\end{array}$ \\
\hline
\end{tabular}

${ }^{74}$ Grameen Foundation Mobile Money Capacity Statement Report 


\begin{tabular}{|c|c|c|c|c|c|}
\hline $\begin{array}{l}\text { Community Agent } \\
\text { Network (CAN) } \\
2016-2019\end{array}$ & $\begin{array}{l}\text { Improving financial } \\
\text { inclusion by delivering } \\
\text { last mile access of } \\
\text { financial products, } \\
\text { services, and financial } \\
\text { literacy to smallholder } \\
\text { farmers in remote } \\
\text { areas }\end{array}$ & $\begin{array}{l}\text { Smallholder farmers in } \\
\text { the Philippines need to } \\
\text { reduce the time spent } \\
\text { traveling to access } \\
\text { financial services. } \\
\text { Field agents need to } \\
\text { provide farmers access } \\
\text { to financial services and } \\
\text { products in real-time. } \\
\text { Widespread use of } \\
\text { mobile technology and } \\
\text { digital platforms offer } \\
\text { opportunity to meet this } \\
\text { need. }\end{array}$ & $\begin{array}{l}\text { JP Morgan Chase } \\
\text { Foundation supported } \\
\text { the implementation of } \\
\text { Sari Saris (a network of } \\
\text { village agents). The } \\
\text { mobile app was } \\
\text { deployed on tablets. } \\
\text { Armed with digital } \\
\text { technology, Sari Saris } \\
\text { implemented last mile } \\
\text { financial service delivery } \\
\text { and education to } \\
\text { smallholder farmers. } \\
\text { In partnership with local } \\
\text { Fintech giants: } \\
\text { Action.Able, Inc., and } \\
\text { Payswitch Fintech } \\
\text { Ventures, Grameen } \\
\text { Foundation designed a } \\
\text { digital financial services } \\
\text { platform, Panalo that } \\
\text { acted as a digital "point } \\
\text { of service” for } \\
\text { transactions and it } \\
\text { enabled direct } \\
\text { connection over any } \\
\text { mobile network with any } \\
\text { bank, government } \\
\text { agencies, utility } \\
\text { companies and other } \\
\text { businesses. }\end{array}$ & $\begin{array}{l}\text { Sari Sari store } \\
\text { operators became the } \\
\text { points of contact for } \\
\text { payments services, } \\
\text { money transfer to } \\
\text { loved ones, money } \\
\text { deposits into digital } \\
\text { account sand much } \\
\text { more. } \\
\text { This digital access } \\
\text { reduced hours and } \\
\text { money that people } \\
\text { spent traveling to } \\
\text { distant bank branches. } \\
\text { Sari Saris received an } \\
\text { incentive for each } \\
\text { transaction, and as a } \\
\text { result, they became } \\
\text { micro entrepreneurs. }\end{array}$ & $\begin{array}{l}\text { CAN agents facilitated } \\
\text { more than } 4.3 \text { million } \\
\text { transactions valued at } 1.3 \\
\text { billion Philippine Pesos } \\
\text { equivalent to } \$ 24.9 \mathrm{M} \text {. } \\
\text { CAN created jobs for } \\
1,900 \text { agents, } 75 \text { percent } \\
\text { were women. }\end{array}$ \\
\hline $\begin{array}{l}\text { Accelerator } \\
\text { Digitizing } \\
2012-2016\end{array}$ & $\begin{array}{l}\text { Improving financial } \\
\text { inclusion by delivering } \\
\text { last mile access of } \\
\text { financial products, } \\
\text { services, and financial } \\
\text { literacy to smallholder } \\
\text { farmers in remote } \\
\text { areas. }\end{array}$ & $\begin{array}{l}\text { Financial service } \\
\text { providers and clients in } \\
\text { rural Uganda need to } \\
\text { reduce time spent } \\
\text { traveling to access } \\
\text { financial services. } \\
\text { Widespread use of }\end{array}$ & $\begin{array}{l}\text { Grameen collaborated } \\
\text { with two financial } \\
\text { service providers: } \\
\text { Centenary Bank and } \\
\text { Pride Microfinance Ltd. } \\
\text { a fully owned } \\
\text { government financial } \\
\text { institution; a mobile }\end{array}$ & $\begin{array}{l}\text { The new service } \\
\text { enabled fast, flexible, } \\
\text { secure, and remote } \\
\text { transactions for any of } \\
\text { Centenary Bank and } \\
\text { Pride Bank's clients. } \\
\text { Banks tapped into a }\end{array}$ & $\begin{array}{l}\text { By its close, the system } \\
\text { had enabled over } 170,000 \\
\text { rural customers to gain } \\
\text { access to their accounts } \\
\text { over this digital channel. } \\
\text { The number of clients } \\
\text { continued to grow by }\end{array}$ \\
\hline
\end{tabular}




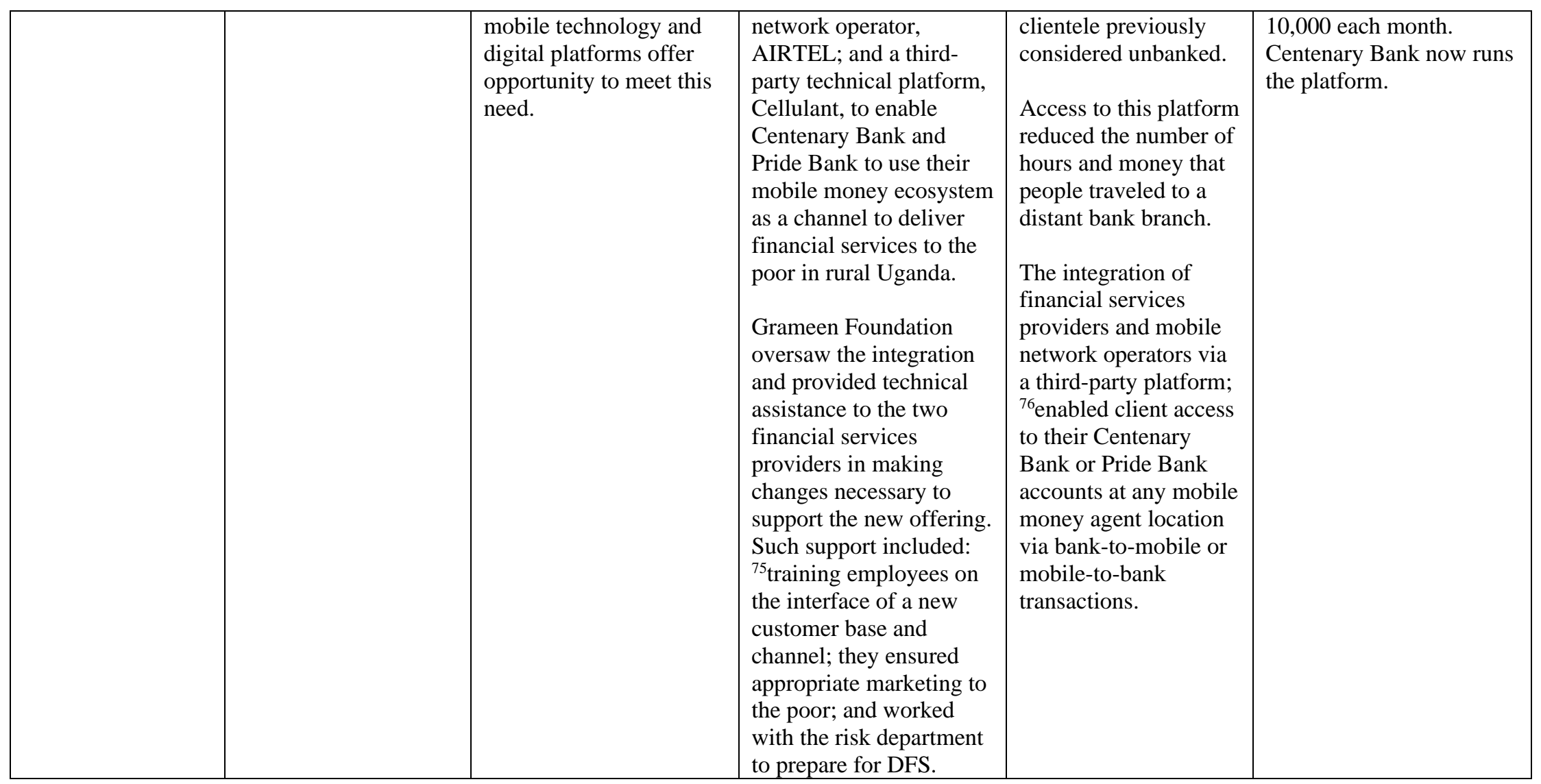

${ }^{75}$ Ibid
${ }^{76}$ Ibid 


\section{VI.4 Innovation Program IV: Scaling Solutions (SS)}

The delivery of sustainable, scalable solutions that ultimately reach millions requires new business models for measuring outcomes and impact, improving efficiencies, strengthening organizational capacities as well as diverse and sustainable sources of funding. To attain this, organizations need financial mechanisms such as impact investments and innovative partnerships to ensure a sustainable scale ${ }^{77}$. Through the SIP process, Grameen pioneered market-based solutions in how they run their daily activities. Prior to designing innovative products and services, Grameen Foundation engaged in activities to fully understand the needs of the clients. As such, these innovations were informed by participatory feedback generated from extensive studies conducted by Grameen Foundation and its partners. Unlike the for-profit sector, Grameen shared its market-based solutions with the industry; its open source approach to innovating enabled many NGOs, MFIs, social enterprises, academia, and governments to scale financial interventions targeted for the poor. Christine, Country Manager, Philippines comments:

"In developing digital tools or product and services, we always coordinate with local partners and target beneficiaries. We do prototyping and role-playing activities with actual users/beneficiaries to seek their response. They provide suggestions for improvement. The more user feedback, the better we are able to maintain good relationships, progress in timeline goals and become more transparent with resource and domain needs."

In this section, we discussed SS innovative activities, some of which are spin-offs, as seen in the timeline of the key SS activities Figure 9 (below). We apply DCT to each activity to show how Grameen Foundation innovated SS activities from ordinary capabilities through Sensing, Seizing, and Transforming.

77 www.grameenfoundation.org 
Figure 9: Timeline of Scaling Solutions (SS)

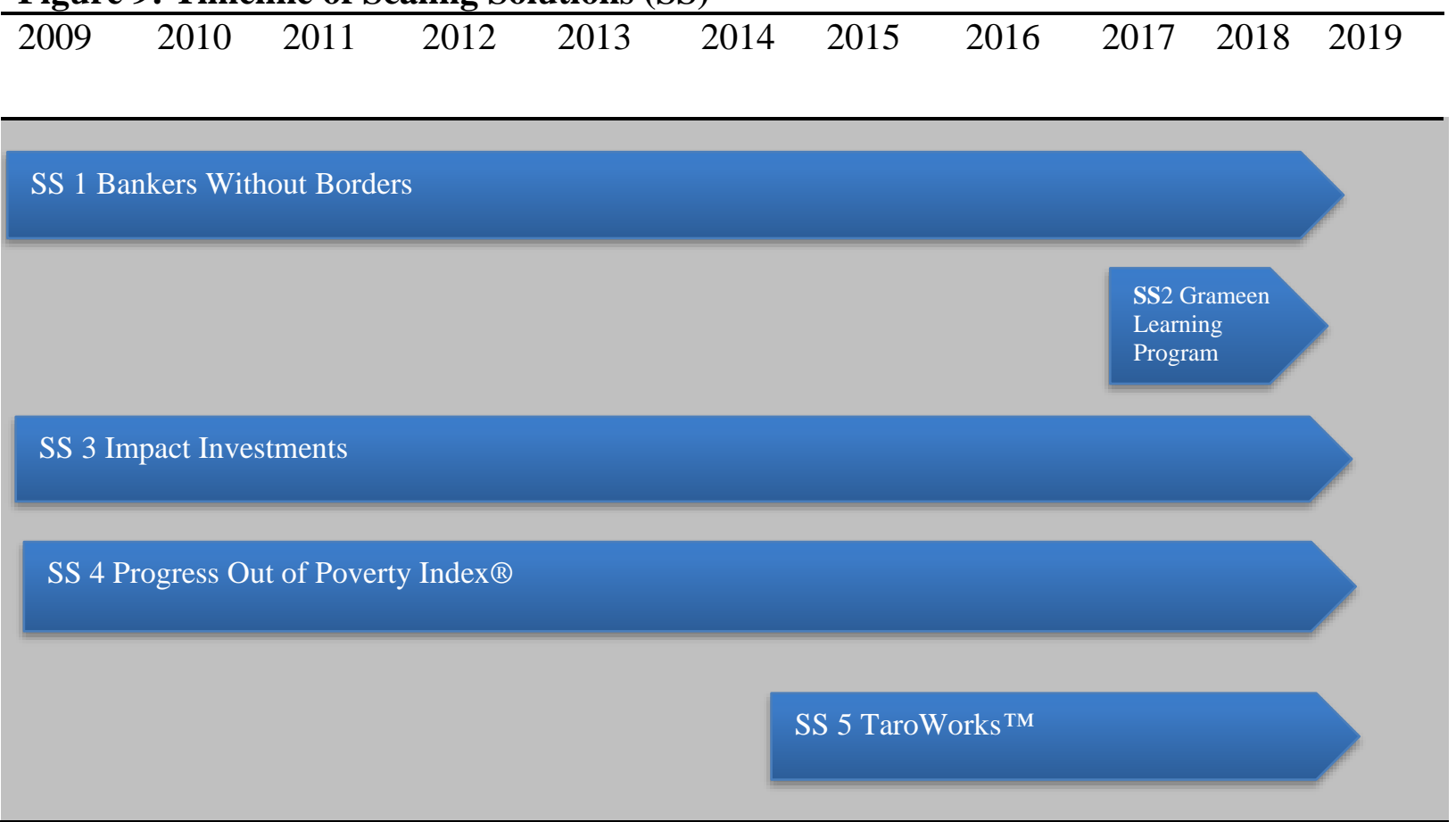

6.4.1 Bankers without Borders (BwB), 2008 - 2019

Sensing: Microfinance Institutions and other financial service providers need ongoing technical assistance to strengthen their capacity for providing financial access to the poor. Grameen Foundation recognized that huge gaps existed on the demand side as well as the supply side in the number of well-trained people with finance expertise to offer affordable and accessible technical assistance to MFIs and their field agents. Opportunities to provide technical support to MFIs and other financial services providers existed within the Grameen Foundation.

Seizing: In 2008, Grameen Foundation received funding from “JP Morgan, the investment bank of about $\$ 5$ million over five years. With this funding, Grameen Foundation designed a professional volunteer platform, Bankers without Border (BwB) automated on salesforces.," comments Sabrina, Director of Bankers without Borders. BwB matched and mobilized the talent and skills of private sector volunteers to accelerate the progress of social 
entrepreneurs dedicated to connecting the poor to their potential by supporting the missions ${ }^{78}$ of poverty-focused social enterprises. Sabrina, Director of BwB comments:

"Bankers without Borders is a 10-year old initiative of Grameen Foundation and really started at the auspices of the Nobel Prize. A lot of micro finance institutions had been knocking on our doors saying, how can we get engaged in the sector? You know, how can we learn about microfinance? And so we saw this as an opportunity for developing a platform to really leveraging all the private sector support to volunteer some of their time in the microfinance sector."

BwB recruited volunteers from top 500 companies in the US who signed up for short assignments overseas via a voluntary agreement and received training from Grameen Foundation's online courses and webinar series ${ }^{79}$. According to Sabrina, their current volunteer base has served different sectors beyond microfinance. Initially, Grameen leveraged volunteers from the financial sector and deployed them to provide technical professional services to MFIs around the world. However, they realized that it was costly and not viable. Grameen's BwB innovated their delivery model to suit market-based solutions that fit both volunteer and client needs. In the adjusted model, BwB leveraged technology to bridge the gap in distance while delivering pro bono virtual technical support in real-time solutions. Sabrina, Director of BwB comments:

"One of our innovations within BwB is what we call crowdsourcing. And the one that we do is an ideation session where we bring a room full of volunteers to brainstorm a challenge with the nonprofit, you know, somewhere in rural Kenya or wherever, over a two-to three-hour facilitation session"

Transforming: An independent evaluation of the impact of BwB for participating volunteers reported the following gains from the program. ${ }^{80}$ First, they derived personal satisfaction from helping the poor (71\%). Second, they expanded their personal and professional ${ }^{78}$ Ibid
79 Ibid
${ }^{80}$ Ibid 
networks (61\%). Third, they gained exposure to a new sector (i.e., MF or social enterprise).

Fourth, they acquired experience in a new region of the world, and lastly, they built their

professional or technical skills. A BwB volunteer comments:

"I cannot fix cleft palates, design clean water systems or develop innovative agricultural techniques, but I've found that my banking experience and financial experience is much appreciated in the developing world."

According to the same report, BwB provided win solutions for companies in the USA that enabled their employees to fulfill volunteerism and impacted the world in meaningful engagements. Sabrina, Director BwB comments:

"The volunteers get recognized. And for us, those client organizations are not a one-time thing. They could be a team of Google servicing them on a project and in six months, you know, JP Morgan group is assisting them. So for us, those are recurring clients."

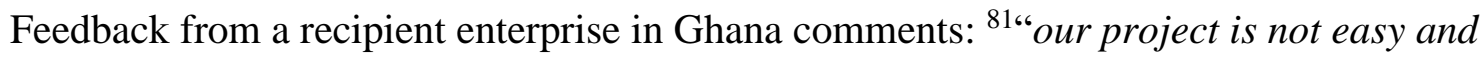
the Google team attacked it eagerly and intelligently.” Janet, Project Manager, MOTECH Ghana. BwB became a self-sustaining activity within Grameen Foundation as they charge a facilitation fee to companies. Through BwB, Grameen facilitated corporate social responsibility employee programs as the flagship volunteer program for top 500 companies including Google and Microsoft like the "Global Fellows, at Google" Sabrina, Director of BwB, comments:

"We charge a fee for service programs, most companies have employee engagement efforts or CSR efforts or HR, but the fee is nothing compared to the quality of service. With JP Morgan we used to deploy a hundred of their volunteers a year, with Google, we do their global fellows program with 16 employees a year. For instance, Wells Fargo gives staff five weeks of paid volunteering and Google sends 16 employees every three months, some of them have gone out to Kenya for three weeks to volunteer on the ground, all expenses covered by Google."

81 Ibid 
Outcomes: Having started with only 100 volunteers in 2008 , today, nearly 20,000 business professionals, academics, and students from 170 countries have contributed their time, skills, and expertise to strengthening organizations fighting global poverty. Since its establishment, the initiative reported the completion of over 1,100 projects and donation of over 278,000 hours, with a value of over $\$ 27.3$ million of probono services. ${ }^{82}$ Sabrina, Director of BwB comments: "Today, at BwB we are serving 264 social enterprises in 48 countries." 6.4.2 Grameen Learning Program (G-LEAP), 2018 - 2019

Sensing: Field agents serving rural clients in India need to share information on financial access and financial literacy. Grameen Foundation in India sensed that gaps exist for field agents to expand their reach and operate more efficiently and cost-effectively. Widespread use of mobile technology offered opportunities to deliver information at scale, more cost-effectively and between field agents and rural clients.

Seizing: Grameen Foundation India pioneered an e-learning app platform called G-Leap through a partnership with Sonata, Oxigen Money, and Citi. G-LEAP was designed as part of a broader initiative aimed at Integrating digital financial services \& education delivery ${ }^{83}$. G-LEAP was the first of its kind android-based e-learning application for front-line workers of NGOs and financial institutions in India. It enabled real-time training of front line microfinance staff and agents. It works quickly and cost-effectively, helping agents engage, educate, and motivate microfinance clients. G-Leap allows field officers to learn on the job while continuing to serve their clients ${ }^{84}$. Through the use of G-LEAP and field agents called "Mitras," Grameen

\footnotetext{
82 www.grameenfoundation.org

83 Times India, Newspaper, 2018

${ }^{84}$ G-Leap Grameen Foundation Digital Literacy Interventions Report
} 
Foundation enhanced the delivery and use of mobile financial services in underserved

communities of India ${ }^{85}$. Phrabat, Country Director of Grameen Foundation India comments:

"G-leap has an E learning platform, which works on mobile and android phones. So we use G-leap for the purposes of financial education and digital financial literacy. We have all the modules loaded on to train the Mitras, or when we are training the staff of the MFI partners. So what G-leap does is that, you know, it makes the training more effective because, you know, nothing is missed out and because the eLearning module is on their mobile phone and they can go back to the learning modules if they have missed out on something."

The successful implementation of G-LEAP depended on how quickly the Mitras adopted and translated it into digital financial literacy and inclusion to others living in remote places.

Phrabat, Country Director of Grameen Foundation India comments:

"So for that we set up an agent network, we call them Grameen Mitra, in Hindi it means a friend, it also means a villager. The Mitras are catalysts of change in ensuring the training, the usability of financial products and introduction of other products to the clients. Lack of customer education or financial education and financial literacy, is a reason people don't use services. So that's why engaging with the customers in financial education creates demand for these products. And then when the demand is created, agents supply financial services to their customers."

Transforming: G-LEAP was initially started as part of a broader initiative that enhanced the delivery and use of mobile financial services in underserved communities initially designed in its in India, Grameen Foundation developed e-Learning courses and digital tools to build the skills of microfinance institutions and development organizations' frontline officers who led women's savings, credit and self-help groups ${ }^{86}$. As such, G-Leap digital training manuals have been translated into Spanish, containing a set of six Spanish-language courses aimed at developing skills in consumer protection, group facilitation, and techniques for delivering nonformal education, and microcredit products management ${ }^{87}$. Grameen Foundation India continued

\footnotetext{
${ }^{85}$ Ibid

${ }^{86}$ Ibid

${ }^{87}$ Ibid
} 
work on to make G-LEAP with a goal to avail it to the larger financial inclusion sector. Phrabat, Country Director of Grameen Foundation India comments:

"At Grameen, we believe that technology provides unique opportunities to make financial services more accessible to poor and remote or excluded populations. We leverage technology to improve the scale, the outreach and the cost effectiveness of our trainings. In the past few years, Grameen Foundation has implemented different initiatives leveraging eLearning, m-Training and m-Learning to equip our partners'staff and deliver trainings in remote areas."

Outcomes: Still in its nascent years, this award-winning, multi-language tool benefited over $3,500^{88}$ front line workers from India, Ecuador, Guatemala, Mexico, and Peru.

\subsubsection{Impact Investments, 2005 - 2019}

Sensing: In addition to engaging in fundraising efforts, Grameen Foundation invested in donor funds to generate social impact along with financial returns ${ }^{89}$. These investments provided the capital needed for MFIs and social enterprises whose products and services benefit the poor. The microfinance boom of the early 2000s resulted in an influx of international capital in the sector. The challenge this boom created for MFIs was that 86 percent of available funding was in U.S. dollars or euros, and yet all of the MFIs' loans to clients were in their respective local currencies. The excessive foreign exchange posed a risk for MFIs when they repaid funders ${ }^{90}$. In addition to mitigating risks, MFIs needed to build relationships with their local capital markets, which could offer stable sources of financing in times of political or economic challenges. With its expertise in creating linkages with financial institutions, Grameen Foundation saw an opportunity to address the need for more financing, and the critical need for MFIs to access financing in their local currencies.

\footnotetext{
${ }^{88}$ Ibid
}

${ }^{89}$ www.grameenfoundation.org

${ }^{90}$ Grameen Foundation Growth Guarantee Program Report, 2005 - 2015 
Seizing: Through a partnership with Schwab Charitable Trust, USAID, and Citi, Grameen Foundation's flagship impact investment product, Growth Guarantee program, was designed in 2005 to establish and scale MFI relationships with local banks and leverage local currency financing to reduce overall exposure to foreign currency risk ${ }^{91}$. The Growth Guarantee program offered a unique opportunity for individuals or institutions to leverage their own assets to make a significant impact in the lives of micro-entrepreneurs in the poorest regions of the world. Rather than act as direct funders to MFIs, they became donor-guarantors by providing a pledge of assets or a bank guarantee to Citi. Citi aggregated and managed all of the guarantees as a collateral pool, which was used to issue standby letters of credit to local lenders to support MFIs. The program was a uniquely flexible model using banking instruments to catalyze local financial markets to work on behalf of the world's poor. It was structured to have a multiplier effect, requiring local lenders to take on a portion of the direct credit risk of the MFI. Each dollar provided as a guarantee was leveraged an average of four times for the MFIs in its own currency. ${ }^{92}$

Transforming: While the Growth Guarantee program was the flagship vehicle for impact investing at Grameen Foundation, other impact funds followed, such as the Pioneer Fund (2010 - 2011) and the Human Capital Center $\left(2012\right.$ - 2019) ${ }^{93}$ These funds utilized mobile technology to deliver innovative and scalable solutions for early-stage social enterprises.

Apart from the impact on individual families, the program spearheaded a movement that provided local currency financing for microfinance institutions. The program also helped change the market's perception of the risk of lending to microfinance institutions, which unlocked far

\footnotetext{
91 Ibid

92 Ibid

93 Ibid
} 
more capital, as seen in figure 10. As mentioned earlier, in the early 2000s, 86 percent of financing offered globally to microfinance institutions was in foreign currency; by 2011 that proportion had already fallen to 69 percent. In addition to the direct impact created, the program pioneered a unique way to use donor assets, a structure that has been adopted by organizations such as Habitat for Humanity. ${ }^{94}$

Outcomes: The Growth Guarantee program became one of the most successful global efforts to unlock capital for microfinance clients, as seen in figure 10. With support from 14 donor-guarantors, the program placed $\$ 59.6$ million in guarantees and generated more than $\$ 235$ million in financing for MFIs while maintaining record low default rate of $0.3 \%{ }^{95}$ over a period of 10 years. With every dollar placed in guarantees leveraging an average of $\$ 4$ in financing for microfinance institutions, the Growth Guarantee program enabled them to provide loans to more than 1.2 million borrowers and their families in twelve countries.

${ }^{94}$ Ibid

${ }^{95}$ Ibid 
Figure 10: Grameen Foundation Impact Investments: Growth Guarantee Program

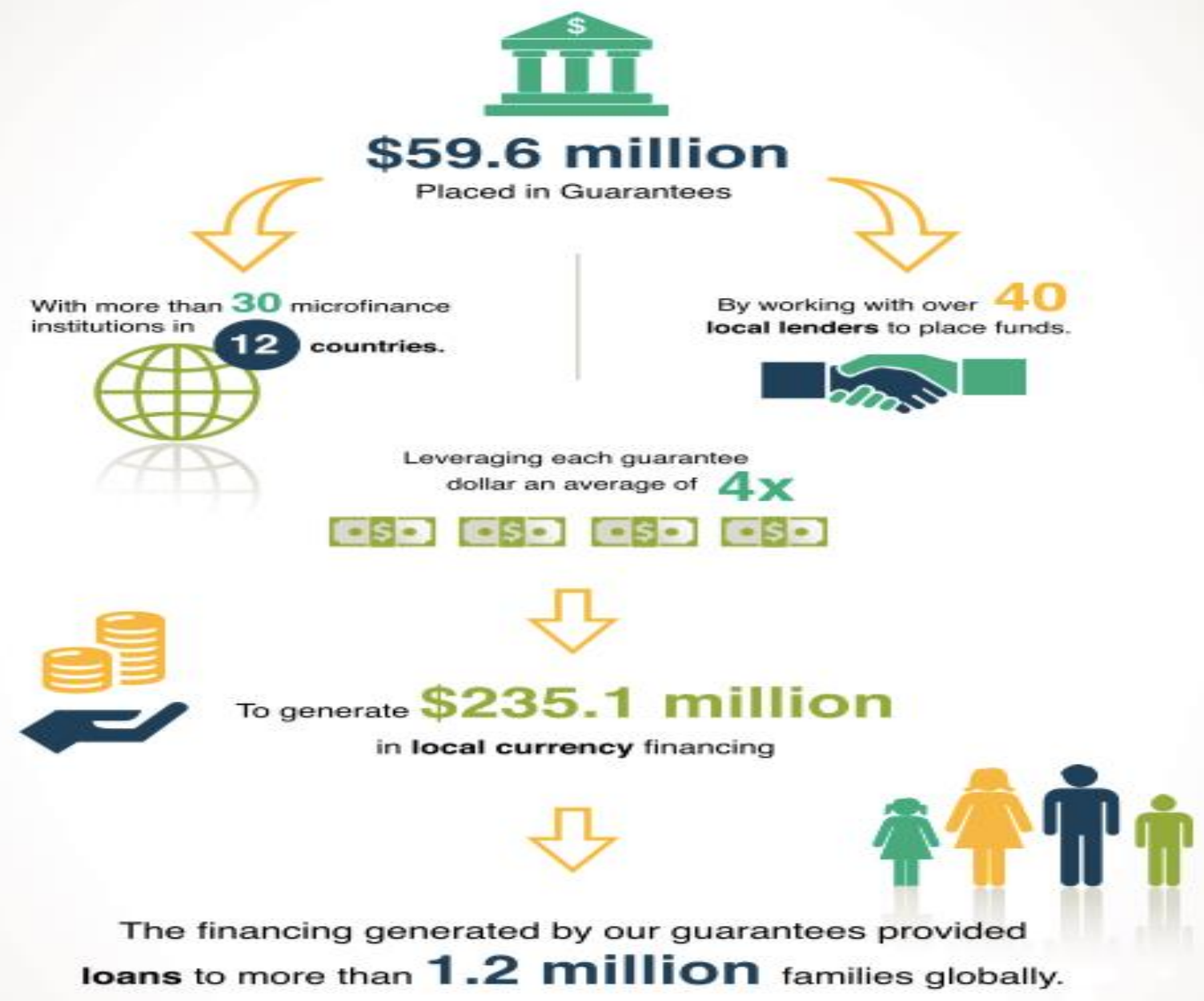

Source: Grameen Foundation Growth Guarantee Program Report, 2005 - 2015

6.4.4 Progress out of Poverty Index (PPI®, $2005-2019$

Sensing: Field agents working in poverty-fighting organizations need to have reliable and accurate poverty data on rural households and to monitor progress, quality, and outcome their own performance. Tools exist within Grameen to collect poverty data on rural households and to determine financial interventions. 
Seizing: In 2005, Grameen Foundation, in partnership with the Consultative Group to Assist the Poor (CGAP) and Ford Foundation, developed the PPI ${ }^{9}{ }^{96}$ Their goal was to create an easy-to-use poverty measurement tool for microfinance institutions containing reliable poverty data that managed their social performance. After pilot testing the PPI®, Grameen Foundation instituted a training program for MFIs interested in using the PPI®, which helped to facilitate the initial adoption of the tool. PPI® utilized a 10-point scorecard of easy-to-answer questions that a household member answered in as little as ten minutes. Asked about the continuous improvement of tools like PPI ${ }^{\circledR}$ and other innovation across programs, Christine, Country Manager Grameen Foundation, Philippines comments:

"We do our own research work to keep up to date with trends and local/global practices. We participate in roundtable discussions and conferences for knowledge exchange and to seek out potential partners for new program rollouts. Internally, we do have reporting systems and quarterly updating in place for local offices to serve as a soundboard of ideas to our other colleagues."

Transforming: Today, the PPI has proved its reliability and feasibility to many organizations around the world. Organizations that collect poverty data from all or a statistically significant sample of households were able to: measure poverty outreach (i.e., the portion of customers, clients, or employees who live below the poverty line), improve the performance of the intervention among the poor and poorest, and track poverty levels over time. With these data, management staff made informed decisions and assessments as well as provided stakeholders with objective evidence that the organization targeted the poor.

Outcomes: The PPI has been used by over 600 organizations, including international NGOs, social ${ }^{97}$ enterprises, donors, investors, multi-national corporations, and governments

${ }^{96}$ Ibid

${ }^{97}$ www.grameenfoundation.org 
across a variety of sectors, including agriculture, healthcare, education, energy, and the financial sector. In July 2016, to facilitate the long-term sustainability of the tool, the PPI Alliance was formed of which from Grameen Foundation became a member in October 2017. The PPI® was rebranded and moved from Grameen Foundation to the custody of the Institute for Poverty Action (IPA) at the Massachusetts Institute of Technology, comments Julian, Technical Advisor for Agriculture Innovation comments:

"We developed the PPI® to help us measure the percentage of a households below the poverty level by asking 10 questions to help us understand the three main metrics using three indicators: percentage of poor persons, number of women in the program and number of extreme poor in the program."

6.4.5 TaroWorks ${ }^{\mathrm{TM}}, 2015-2019$

Sensing: Field agents working in rural areas need to collect data and analyze it in reasonable time to assess the financial needs of rural clients. Widespread use of mobile technology offers opportunities to collect and analyze data in real-time.

Seizing: In 2015, Grameen Foundation obtained funding from Cisco and Qualcomm to design TaroWorks ${ }^{\mathrm{TM}}$, an iCloud based management and data collection software. ${ }^{98}$ Grameen Foundation originally designed TaroWorks ${ }^{\mathrm{TM}}$ to ease the integration of data collection and analysis between field staff that worked in hard to reach areas and office staff. Today, there are more users of this software who buy license subscriptions. Brent, Chief Executive Officer of TaroWorks ${ }^{\mathrm{TM}}$ comments:

"Taroworks started as a project at Grameen Foundation, it was incubated for a couple of years and then we became an independent company in 2015. So the software was developed for Grameen to manage the operations of it projects, both to collect live data and then also to manage business operations of fields projects."

98 www.grameenfoundation.org 
Taroworks ensured continuous business improvement by utilizing the efficiencies of captured data from clients and by applying that efficiency to measure the value addition ensuring customer satisfaction and usage. TaroWorks ${ }^{\mathrm{TM}}$ provided ongoing support to customers, such as training on new features and through new rollouts. Advising their clients transformed how organizations collected and analyzed data in real-time. Brent, Chief Executive Officer of TaroWorks ${ }^{\mathrm{TM}}$ comments:

"We support a lot of customers in their programs, be it job training, education, welfare type programs, solar clean energy programs like cook stoves, bio gas etc. Recently, we facilitated the training and graduation of clients by the Boma project in northern Kenya and Uganda that help women start businesses and form saving groups. In Haiti, Taroworks has supported a microfinance organization to manage their integration with a health care program. With Taroworks they achieved efficiencies in managing inventory in their health program."

Transforming: In terms of utility, TaroWorks ${ }^{\text {TM }}$ helped organizations to create marketbased solutions with some enhancements tailored to the various client needs, as such TaroWorks ${ }^{\mathrm{TM}}$ has a growing global clientele comments Brent: “We operate in a wide variety of industries but our two major sets of customers today are NGOs and then also social enterprises."

TaroWorks ${ }^{\mathrm{TM}}$ has added more features since its spin-off and this ability to evolve enabled

Grameen Foundation to register scalable gains in innovation across all programs, Brent, the Chief Executive Officer of Taroworks ${ }^{\mathrm{TM}}$ comments:

"It's a two-way information exchange between the mobile user and the office staff. One half is an android application that's used in the field, usually in an offline environment by the field staff to either collect information or show business forms, or look up information about people they're working with. And the second half of it is a management application that is a salesforce.com application. And that's used as an application in salesforce.com instance for the management of the mobile users and the synchronization, the banner from the mobile devices back to back to the banks.

Outcomes: In just a few years, TaroWorks ${ }^{\mathrm{TM}}$ grew exponentially from its humble beginning as an in-house data collection and analysis tool used by Grameen Foundation staff to a 
spin-off and global utility by NGOs and by more than 90 social enterprises.$^{99}$ Its mobile application supported over 200,000 micro-entrepreneurs and improved the lives of more than four and a half million poor beneficiaries across 30 countries $^{100}$. Brent, Chief Executive Officer of TaroWorks ${ }^{\mathrm{TM}}$ comments:

"When we became an independent organization, we had about 23 customers and roughly 1600 users or so. And now we have over 90 customers and we've grown over four times the number of users and, about three times number of customers since we became an independent company."

\subsubsection{Summary of SS}

Sensing: Grameen Foundation sensed that in order to improve financial inclusion for rural households, it needed to strengthen the organizational capacities of MFIs to ensure a sustainable scale. Such support included financing, financial literacy, and ongoing technical support. Grameen Foundation further observed that to strengthen its business processes, it had to measure outcomes, performance, and impact; and collect reliable and accurate poverty data in real-time. The widespread use of mobile technology, an abundance of skilled professions, and the existence of capital markets that yield high returns provided opportunities to address those gaps.

Seizing: Grameen seized by partnering with funders and technology platforms to design $\mathrm{BwB}$, an enterprise within Grameen Foundation used to recruit and deploy professionals matching needs of MFIs in need of capacity building and training short periods for free. To fill the training gaps faced by frontline workers, Grameen Foundation designed an electronic training manual called G-LEAP deployed on tablets that enabled scaling of training on financial services in remote areas. PPI $®$, a poverty metric measuring tool, was designed and used to

${ }^{99}$ Ibid

${ }^{100}$ Ibid 
determine financial interventions based on household poverty metrics. Taroworks, a cloud based app that utilized sales force, was designed to enable field workers working in remote places to collect data and analyze it in real-time.

Transforming: Through the SIP process, Grameen pioneered innovative products, professional services, and processes in the way they run their daily activities from "ordinary" capabilities into products and professional services solutions and processes with greater value addition (dynamic capabilities). Over time as seen in Tables 8, Grameen's in house digital innovative products like TaroWorks ${ }^{\mathrm{TM}}$, G-Leap, PPI® and professional services like BwB were shared with other MFIs and NGOs and became the standard for metric measurement, monitoring, and evaluation as well as data collection and analysis tools for industry-wide MFIs, NGOs and Social enterprises involved in microfinance and poverty alleviation worldwide.

Outcomes: Grameen Foundation's scalable solutions enabled significant scaling of financial access to the poor who live in hard to reach areas. TaroWorks ${ }^{\mathrm{TM}}, \mathrm{PPI} 囚$, G-Leap, BwB have been used by over 600 organizations in over 40 countries. Through BwB, over 1,100 projects were completed by over 20,000 volunteers who donated over 278,000 hours, and served over 264 social enterprises in over 48 countries with a value of over $\$ 27.3$ million in probono professional services. ${ }^{101}$ The translation of G-Leap into Spanish enabled over 3,500 front line workers from India to Ecuador, Guatemala, Mexico, and Peru benefited from using the Spanish version of G-Leap. Finally, through impact investment, Grameen Foundation worked with 40 local financial institutions to generate $\$ 235.1 \mathrm{M}$ that enabled $30 \mathrm{MFIs}$ to provide loans to more than 1.2 million families in 12 countries.

${ }^{101}$ www.grameenfoundation.org 
Table 8: Summary of Scaling Solutions (SS) Innovations (2009 - 2019)

\begin{tabular}{|c|c|c|c|c|c|}
\hline \multirow{2}{*}{ Activity } & \multirow{2}{*}{$\begin{array}{c}\text { Ordinary } \\
\text { Capability }\end{array}$} & \multicolumn{4}{|c|}{ Dynamic Capability } \\
\hline & & Sense & Seize & Transform & Outcomes \\
\hline $\begin{array}{l}\text { Bankers without } \\
\text { Borders (BwB) } \\
2008-2019\end{array}$ & $\begin{array}{l}\text { Measuring outcomes, } \\
\text { performance, and } \\
\text { impact; and } \\
\text { strengthening } \\
\text { organizational } \\
\text { financial and technical } \\
\text { capacities to ensure a } \\
\text { sustainable scale. }\end{array}$ & $\begin{array}{l}\text { Financial services } \\
\text { providers need ongoing } \\
\text { support to strengthen their } \\
\text { capacity. Opportunities to } \\
\text { provide technical support } \\
\text { existed within Grameen } \\
\text { Foundation. } \\
\text { Community Volunteer } \\
\text { opportunities existed with } \\
\text { major corporations to } \\
\text { enable the transfer of and } \\
\text { sharing of technical and } \\
\text { professional services. }\end{array}$ & $\begin{array}{l}\text { BwB matched and } \\
\text { mobilized the talent and } \\
\text { skills of private-sector } \\
\text { volunteers in the USA and } \\
\text { deployed them to } \\
\text { developing countries to } \\
\text { accelerate progress of } \\
\text { MFIs, social enterprises, } \\
\text { and financial partners. } \\
\text { Through partnership with } \\
\text { JP Morgan, the } \\
\text { investment bank, } \\
\text { Grameen Foundation } \\
\text { designed a professional } \\
\text { volunteer platform, } \\
\text { Bankers without Borders } \\
\text { (BwB) automated on } \\
\text { salesforces. }\end{array}$ & $\begin{array}{l}\text { The program offered } \\
\text { volunteers a chance to } \\
\text { impact the world in } \\
\text { meaningful } \\
\text { engagements that } \\
\text { expanded their personal } \\
\text { and professional } \\
\text { networks as they gained } \\
\text { exposure to a new } \\
\text { sector. } \\
\text { BwB is a flagship } \\
\text { volunteer program for } \\
\text { top Fortune } 500 \\
\text { companies, including } \\
\text { Microsoft, Wells Fargo } \\
\text { and Google. }\end{array}$ & $\begin{array}{l}\text { BwB begun with } 100 \\
\text { volunteers in } 2008, \text { to } \\
\text { over } 20,000 \text { volunteers } \\
\text { from } 170 \text { countries have } \\
\text { completed over } 1,100 \\
\text { projects and donated } \\
\text { over } 278,000 \text { hours, } \\
\text { with a value of over } \\
\$ 27.3 \mathrm{M} \text { in probono } \\
\text { professional services. } \\
\text { BwB has supported } 264 \\
\text { social enterprises, } \\
\text { including MFIs in } 48 \\
\text { countries. }\end{array}$ \\
\hline $\begin{array}{l}\text { Grameen } \\
\text { Learning Program } \\
\text { (G-leap) } \\
\mathbf{2 0 1 8}-\mathbf{2 0 1 9}\end{array}$ & $\begin{array}{l}\text { Measuring outcomes, } \\
\text { performance, and } \\
\text { impact; and } \\
\text { strengthening } \\
\text { organizational } \\
\text { financial and technical } \\
\text { capacities to ensure a } \\
\text { sustainable scale. }\end{array}$ & $\begin{array}{l}\text { Field agents and rural } \\
\text { clients need to share } \\
\text { information on financial } \\
\text { access and financial } \\
\text { literacy. } \\
\text { Widespread use of mobile } \\
\text { technology offers } \\
\text { opportunities to deliver } \\
\text { information on access to } \\
\text { financial services and } \\
\text { financial literacy in a } \\
\text { cost-effective way within } \\
\text { Grameen Foundation. }\end{array}$ & $\begin{array}{l}\text { Mitras in India } \\
\text { implemented financial } \\
\text { trainings. G-Leap was } \\
\text { deployed on tablets and it } \\
\text { enabled Mitras to scale } \\
\text { training on financial } \\
\text { services in remote areas. } \\
\text { Grameen Foundation and } \\
\text { partners in India designed } \\
\text { G-LEAP to provide } \\
\text { Integrated Digital } \\
\text { Financial Services \& } \\
\text { Education Delivery. }\end{array}$ & $\begin{array}{l}\text { Grameen Foundation } \\
\text { India continued to } \\
\text { refine work on G-LEAP } \\
\text { with a goal to avail it to } \\
\text { the larger financial } \\
\text { inclusion sector. } \\
\text { G-Leap training } \\
\text { modules have been } \\
\text { translated into Spanish. }\end{array}$ & $\begin{array}{l}\text { G-Leap is an Award- } \\
\text { winning training App } \\
\text { G-Leap brought about } \\
\text { scale by enabling the } \\
\text { training of thousands of } \\
\text { users without any costs } \\
\text { in travel. } \\
\text { 3,500 front line workers } \\
\text { from India to Ecuador, } \\
\text { Guatemala, Mexico, } \\
\text { and Peru benefited from } \\
\text { G-Leap. }\end{array}$ \\
\hline
\end{tabular}




\begin{tabular}{|c|c|c|c|c|c|}
\hline $\begin{array}{l}\text { Impact } \\
\text { investments } \\
2005-2019\end{array}$ & $\begin{array}{l}\text { Measuring outcomes, } \\
\text { performance, and } \\
\text { impact; and } \\
\text { strengthening } \\
\text { organizational } \\
\text { financial and technical } \\
\text { capacities to ensure a } \\
\text { sustainable scale. }\end{array}$ & $\begin{array}{l}\text { MFIs need to establish } \\
\text { relationships with local } \\
\text { banks and leverage local } \\
\text { currency financing to } \\
\text { reduce overall exposure to } \\
\text { foreign currency risk. }\end{array}$ & $\begin{array}{l}\text { Through partnership with } \\
\text { Schwab Charitable Trust, } \\
\text { USAID and Citi. } \\
\text { Grameen Foundation's } \\
\text { flagship impact } \\
\text { investment product: the } \\
\text { "Growth Guarantee," a } \\
\text { flagship program was } \\
\text { designed. Impact } \\
\text { investment activities are } \\
\text { ongoing within SS. }\end{array}$ & $\begin{array}{l}\text { Grameen Foundation } \\
\text { pioneered impact } \\
\text { investing, and other } \\
\text { NGOs like Habitat for } \\
\text { Humanity adopted the } \\
\text { model. } \\
\text { High repayment rates } \\
\text { from MFIs reflected } \\
\text { their low risk. }\end{array}$ & $\begin{array}{l}\text { Grameen Foundation } \\
\text { worked with } 40 \text { local } \\
\text { financial institutions to } \\
\text { generate } \$ 235.1 \mathrm{M} \text { that } \\
\text { enabled } 30 \mathrm{MFIs} \text { to } \\
\text { provide loans to more } \\
\text { than } 1.2 \text { million } \\
\text { families in } 12 \text { countries. }\end{array}$ \\
\hline $\begin{array}{l}\text { Progress out of } \\
\text { Poverty Index } \\
\text { (PPI@) } \\
\mathbf{2 0 0 5 - 2 0 1 9}\end{array}$ & $\begin{array}{l}\text { Measuring outcomes, } \\
\text { performance, and } \\
\text { impact; and } \\
\text { strengthening } \\
\text { organizational } \\
\text { financial and technical } \\
\text { capacities to ensure a } \\
\text { sustainable scale. }\end{array}$ & $\begin{array}{l}\text { Field agents need reliable } \\
\text { and accurate poverty data } \\
\text { on rural households to } \\
\text { determine financial } \\
\text { interventions. } \\
\text { Tools exist within } \\
\text { Grameen to collect } \\
\text { poverty data from rural } \\
\text { household. }\end{array}$ & $\begin{array}{l}\text { Originally designed by } \\
\text { Grameen Foundation with } \\
\text { support from CGAP and } \\
\text { Ford Foundation, PPI® a } \\
\text { poverty metric measuring } \\
\text { tool that utilized a 10- } \\
\text { point scorecard was } \\
\text { developed. } \\
\text { Grameen Foundation } \\
\text { facilitated PPI@'s initial } \\
\text { training for MFIs. }\end{array}$ & $\begin{array}{l}\text { Measuring tool resulted } \\
\text { from evidence based on } \\
20 \text { years experience in } \\
\text { global perspectives and } \\
\text { local knowledge. } \\
\text { PPI@ was spanned off } \\
\text { and housed by the } \\
\text { Innovations for Poverty } \\
\text { Action at the } \\
\text { Massachusetts Institute } \\
\text { of Technology. }\end{array}$ & $\begin{array}{l}\text { PPI® indices are the } \\
\text { metric gold standard in } \\
\text { assessing household } \\
\text { poverty and } \\
\text { interventions. } \\
\text { PPI® has been used by } \\
\text { over } 600 \text { organizations } \\
\text { and has been adopted } \\
\text { by } 40 \text { NGOS } \\
\text { worldwide. }\end{array}$ \\
\hline $\begin{array}{l}\text { TaroWorks }^{\mathrm{TM}} \\
2015-2019\end{array}$ & $\begin{array}{l}\text { Measuring outcomes, } \\
\text { performance, and } \\
\text { impact; and } \\
\text { strengthening } \\
\text { organizational } \\
\text { financial and technical } \\
\text { capacities to ensure a } \\
\text { sustainable scale. }\end{array}$ & $\begin{array}{l}\text { Field agents working in } \\
\text { rural areas need to collect } \\
\text { data and analyze it } \\
\text { quickly. } \\
\text { Widespread use of mobile } \\
\text { technology offers } \\
\text { opportunities to collect } \\
\text { and analyze data in real- } \\
\text { time. }\end{array}$ & $\begin{array}{l}\text { With funding from Cisco } \\
\text { and Qualcomm Grameen } \\
\text { Foundation designed } \\
\text { TaroWorks }{ }^{\mathrm{TM}} \text {, a cloud } \\
\text { based management and } \\
\text { data collection } \\
\text { software. }{ }^{102} \\
\text { TaroWorks } \\
\text { integration of data } \\
\text { collection and analysis for } \\
\text { field and office staff. }\end{array}$ & $\begin{array}{l}\text { Capturing and } \\
\text { analyzing data in real- } \\
\text { time. Copyright of a } \\
\text { mobile cloud app. } \\
\text { Grameen Foundation } \\
\text { Spin off innovation. }\end{array}$ & $\begin{array}{l}\text { More than } 90 \text { social } \\
\text { enterprises have used } \\
\text { TaroWork }{ }^{\mathrm{TM}} \text {. Its mobile } \\
\text { application supported } \\
\text { more than } 200,000 \\
\text { micro-entrepreneurs } \\
\text { And improved the lives } \\
\text { of more than four and a } \\
\text { half million poor } \\
\text { beneficiaries across } 30 \\
\text { countries. }\end{array}$ \\
\hline
\end{tabular}

102 www.grameenfoundation.org

103 Ibid 


\section{VI.5 Cross Program Analysis}

Our analysis across programs revealed some nuanced overlaps characterized by similarities and differences in how Grameen Foundation innovated product, services, and process activities to improve financial inclusion, as shown in Table 9. First, the context through which Grameen Foundation innovated was based on country-specific needs. When they sensed a need, they focused on a very particular program in a country, and when a similar need arose elsewhere, they replicated that innovation across countries and designed features that addressed those country-specific needs. For example, Grameen designed the CKW in Uganda to connect field agents and farmers with shared knowledge on financial access. However, when a similar need arose in Colombia, they replicated CKW with added features and developed M-Sourcing.

The second observation across programs was that technology acted as an enabler for innovation. In different contexts, Grameen Foundation seized the widespread use of mobile technology to design digital financial solutions that were accessible to the target beneficiaries. As an example, in Kenya Grameen leveraged an existing mobile money platform, Mpesa, to design Musoni Kilimo Booster, a digital loan product. In Uganda, Grameen leveraged the national coverage of mobile network operators to design Airtel Weza, a digital mobile money wallet that allowed savings groups to store cash on their phones as opposed to lock boxes.

Thirdly, incremental sources of funding characterize the speed and extent to which nonprofits that are heavily donor funded innovate. We observed that some of these innovations stretched over short periods of time such as Musoni Kilimo Booster 2013 - 2016, while others like Health Protection and Health finance 2006 - 2019 funded by Bill and Melinda Gates Foundation, and BwB (2005 - 2019) funded by J.P. Morgan spanned over ten years. Grameen Foundation's SIP model enabled it to constantly fine-tune solutions such that when funding was obtained, they seized the opportunity to quickly innovate, so the timeline of innovation was 
related to funding. Hence, we concluded that the timeline of an innovative solution depended on funding.

Innovation transfer was the fourth observation, based on the constant application of all three characteristics mentioned above namely: 1) sensing country-specific needs;2) seizing opportunities to leverage existing technology; 3) funding as a key determinant of an innovation's timeline; in addition to leveraging support within an ecosystem of partners who provided financial linkages, positioned Grameen Foundation to attain transformative scale in innovation and even transfer it from country to country. As example, DFDP was designed with support from two global cocoa agribusiness partners, Mars and Rain Forest Alliance, to provide a range of financial and market access benefits for smallholder cocoa farmers in Ghana, Indonesia, and Colombia. Hence, we concluded that Grameen designed innovations that were easily transferable and replicable.

To measure performance and monitor outcomes, Grameen strengthened its internal organizational capacity by designing market-based scaling solutions that they spun off, such as Taroworks ${ }^{\mathrm{TM}}$, PPI ${ }^{\circledR}$, and BwB which they shared with over 600 organizations. ${ }^{104}$ Grameen Foundation leveraged impact investments to generate funds that supported MFIs activities, and in the first ten years, they had generated $\$ 235.1 \mathrm{M} .{ }^{105}$ As an outcome, Grameen Foundation and its partners improved financial inclusion for close ${ }^{106} 12$ million smallholder farmers.

104 Ibid

105 Www.grameenfoundation.org

${ }^{106}$ Ibid 
Table 9: Cross Program Analysis

Characteristic

Country specific needs drove innovation. When Grameen Foundation sensed a need, they focused on a very particular program in a country and when a similar need arose elsewhere, they replicated that innovation across countries and Country Specific designed features that addressed country-specific needs. For example, CKW was first launched in Uganda to connect field agents and farmers with shared knowledge on financial access and when a similar need arose in Colombia, they replicated it with added features and developed M-Sourcing.

\begin{tabular}{|l|l|}
\hline $\begin{array}{l}\text { Existing } \\
\text { Technology }\end{array}$ & $\begin{array}{l}\text { Grameen Foundation seized existing opportunities such as the widespread use of mobile technology to design cloud- } \\
\text { based applications that were easily accessible for field agents and clients. Musoni Kilimo booster in Kenya, a digital } \\
\text { loan that was accessed 100\% on the phone leveraged existing mobile money platforms like Mpesa. Airtel Weza, a } \\
\text { digital finance application was designed by leveraging the extensive coverage of mobile network operators to create } \\
\text { mobile money wallets in Uganda. Hence, existing technology acted as an enabler for innovation. }\end{array}$ \\
\hline $\begin{array}{l}\text { Incremental } \\
\text { Funding }\end{array}$ & $\begin{array}{l}\text { Funding for NGOs tends to be incremental; resulting in some innovations having shorter lifespans such as Musoni } \\
\text { Kilimo Booster 2013 - 2016, while others like BwB 2005 - 2019 had enduring life spans. However, Grameen } \\
\text { Foundation's SIP model enabled it to constantly fine-tune solutions such that when funding was obtained, they seized } \\
\text { the opportunity to quickly innovate. Hence the timeline of an innovative solution depended on funding. }\end{array}$ \\
\hline $\begin{array}{l}\text { Innovation } \\
\text { Transfer }\end{array}$ & $\begin{array}{l}\text { Leveraging support within an ecosystem of partners who provided financial linkages and technical support positioned } \\
\text { Grameen Foundation to attain transfomative scale at innovating and to transfer innovation from country to country. As } \\
\text { example, DFDP was designed with support from two global cocoa agribusiness partners; Mars and Rain Forest alliance } \\
\text { to provide a range of financial and market access benefits for smallholder cocoa farmers. Varying features of DFDP } \\
\text { were piloted and launched in three continents, including Ghana where it was first launched, Indonesia and Colombia. } \\
\text { Hence we concluded that innovation at Grameen Foundation was easily transferable and replicable. }\end{array}$ \\
\hline
\end{tabular}




\begin{tabular}{|l|l|}
\hline & $\begin{array}{l}\text { Grameen strengthened its internal capacity to measure perfomance, monitor, and evaluate outcomes and outputs, by } \\
\text { designing market-based scalable solutions that they spun off such as Taroworks }\end{array}$ \\
$\begin{array}{l}\text { Perfomance PPI } ®, \text { BwB and shared with over } \\
\text { measuring }\end{array}$ & $\begin{array}{l}\text { 600 MFI organizations }{ }^{107} \text {. They leveraged impact investments to generate funds that supported MFIs activities, and in its } \\
\text { first ten years, they had generated } \$ 235.1 \mathrm{M} \text {. As an outcome of impact investments, other products, services, and process } \\
\text { innovations, Grameen Foundation and its partners improved financial inclusion for over } 12 \text { million smallholder farmers } \\
\text { worldwide. } 108\end{array}$ \\
\hline
\end{tabular}

\section{Ibid}

${ }^{108}$ Ibid 


\section{DISCUSSION}

In this dissertation, we carried out an investigation to understand how Grameen Foundation-a nongovernment organization that partners with various MFIs to provide micro loans, savings, and other financial and professional services — has innovated its products, services and processes and the extent to which these activities have improved financial inclusion. We approached the study through a retrospective, longitudinal, qualitative case study (Yin, 2014) based on Dynamic Capability Theory (Teece, 1997, $2012 \&$ 2014). Anchoring the study in DCT allowed us to highlight the unique ways in which Grameen Foundation innovated its products, services, and processes through the three concepts of (1) sensing, (2) seizing, and (3) transforming over a tenyear period 2009 - 2019, and also to report the outcomes of these innovation activities. Based on

these insights, our study offers the following contributions to theory and practice, cf. Table 1: 1) a detailed empirical account of how Grameen Foundation innovated its approach to microfinancing over a ten-year period; 2) advancing theory of MFI innovations based on Dynamic Capability Theory, and 3) practical insights for how MFIs can innovate to improve financial inclusion. In the following, we elaborate on these contributions as they relate to existing theoretical and practical knowledge about innovation in the provision of microfinancing products and services.

\section{VII.1 Empirical Findings}

This study contributes to the existing literature on microfinance by offering a detailed empirical account of how Grameen Foundation innovated its products services and processes to improve financial inclusion. Previous emperical MF studies focused on the high operational costs associated with MF activities (Das, et. al., 2010 \& 2015; Khandikul \& Wydick,1999; Armendariz, 1999 \& 2000; Anderson et al., 2002; Chowdhury, 2005 \& 2009; Mersland, 2010; 
Toindepi, 2014), or lending technologies with poor ICT infrastructure (Helms, 2006; Mersland, 2007; Navajas, et. al., 2003; Frederick, et al., 2009; Moturi \& Mbiwa, 2015), or information asymmetries (McIntosh \&Wydick, 2005; Wright \& Ripley, 2003; Cull et al., 2007; Mersland \& Strom, 2009; Ghosh \& Tassel, 2013), the social and economic outcomes of microfinance (Armendariz \& Morduch, 2010; Banerjee, et. al., 2009; Chandler, 1998; Karlan \& Zinman 2009; Mayoux, 2010), and last but not least, the lack of diverse funding and incentive dependency (Murdoch, 2000; Strom et. al., 2010; Morduch, 1999 \& 2014; Coleman, 1999; Pitt, et. al., Roodman, 2009; Abeysekera et al., 2015) that encumbered MFIs' ability to realize sustainable impact among the poor.

The details we have learned about the various programs and the activities within those programs have given us deeper insight into how Grameen Foundation has innovated over time and consistently been a leader at delivering scalable digital financial solutions such as $\mathrm{CKW}$, Taro works $^{\mathrm{TM}}$, PPI ${ }^{\circledR}$, and BwB. None of the studies had given a comprehensive account of how an international NGO like Grameen Foundation innovated across programs and project activities traversing multiple countries and showed outcomes of its contribution to financial inclusion. Lastly, none of the above studies had offered a detailed process account based on the theory of Dynamic Capabilities.

\section{VII.2 Theoretical Advances}

We applied Dynamic Capabilities Theory (Teece, 1997 \& 2014) and demonstrated that a Dynamic Capability Theory view of innovation in MFI was useful because it allowed us to highlight the interdependencies between its core concepts of sensing, seizing and transforming which helped us uncover the unique ways through which Grameen Foundation innovated its products, services, and processes and consistently created financial linkages through 20 project 
activities in its four programs across countries over a ten-year period with quantifiable outcomes of its contribution toward improving financial inclusion.

We found the usefulness of Dynamic Capabilities Theory concepts of sensing, seizing, and transforming applicable to studies of innovation in microfinance in the nongovernment sector. However, our analysis revealed that there are elements of the theory's core concepts that were not directly applicable. For instance, rather than create Valuable, Rare, Imperfectly Imitable and Non substitutable resources, Grameen's philosophy of creating open-sourced market-based solutions that they shared with industry resulted in "Valuable," "Rare," "Diffusible," and "Non Substitutable" resources that were "transferrable" and "imitable." Hence we concluded that in the context of innovating in non-government microfinance organizations, this concept translated into Transferrable, Valuable, Imitable and Non Substitutable or "TVIN" resources. In his recent paper on DCT, Teece (2014) suggested the need to extend DCT to other sectors as an area for further research. Our study has demonstrated that DCT is an adaptable theory to innovation in microfinance organizations in the not for profit NGO sector.

\section{VII.3 Practical Insights}

Practical insights gleaned from this study were derived from the iterative engagement of scholarship and practice based on the researcher's extensive practitioner experience working with NGOs engaged in microfinance initiatives. The rich primary data presented here and the following findings also summarized in Table 9, provide a resource to guide practitioners of MFIs, social enterprises, academia, governments, and NGOs in their innovation efforts. The five insights from Grameen were; 1) They innovated based on country-specific needs, as an example, in their Agriculture Finance programs, CKW was first piloted based on needs in Uganda but when they sensed similar needs in Colombia, they replicated it with added features and 
developed M-Sourcing; 2) They seized opportunities for existing technology such as mobilebased digital apps to innovate. In Kenya, they designed Musoni Kilimo Booster by leveraging Mpesa and in Uganda, Airtel Weza was designed by leveraging the widespread mobile network operators; 3) That funding projects drove innovation and that it was important to seize opportunities to create financial linkages with multiple partners like banks, donors, and government in order to sustain the innovation; 4) Grameen's SIP model enabled the transformative transfer of innovation. 5. Strengthening the internal capabilities of how performance was measured, monitored, and evaluated for program outputs in order to sustain the scaling of outcomes. Finally, MFIs and other practitioners could utilize Grameen Foundation's easily transferrable notable innovations like BwB, G-Leap, PPI®, and TaroWorks ${ }^{\mathrm{TM}}$.

\subsubsection{Implication to Policy Development}

Policy makers, institutional donors like the World Bank, international development aid agencies like USAID, DFID and others whose monetary policies directly shape the economic trajectories of low to middle income countries can glean insights from this study. The United Nations' Sustainable Development Agenda of achieving a better and more sustainable future for all by $2030^{109}$ recognizes that economic empowerment activities that target women, such as microfinance remain a critical activity with a strong impact on the achievement of other SDGs (Kayongo, Tom \& Mathiassen, 2020). This study has demonstrated that innovation based on the five practical insights that emerged can have far-reaching outcomes for the attainment of the UN's sustainable future for all, even beyond the targeted timeline of 2030.

${ }^{109}$ www.sustainabledevelopment.un.org 


\section{VII.4 Limitations and Future Research}

Critics of single case study design often point to its limited generalizability, as mentioned in Chapter 5. However, the detailed contextual information on Grameen Foundation's individual activities within programs that spanned regions and multiple partners provided in this study addresses the issue of limited generalizability, according to Devers (1999). The details shared will benefit microfinance practitioners and researchers in assessing the transferability of our findings to other contexts (Lincoln and Guba, 1985). We acknowledge that given the everchanging and complex economic environment, it's increasingly harder to predict the effects that unforeseeable circumstances such as health pandemics like Covid19 would have on global financial markets. We recognize that such changes are likely to produce different outcomes for innovation in microfinance and its beneficiaries.

Future studies on innovation in microfinance could benefit from applying other theories such as Social Network Theory, Sense and Respond Theory, or the Organizational Learning Theory as well as various survey instruments or experimental design. Randomized control trials have recently gained acceptance as a useful tool for understanding the economic needs of the poor. The work of 2019 Nobel Laureates in economics: Abhijit Banerjee, Esther Duflo, and Michael Kremer applied "experimental approaches to alleviating global poverty." ${ }^{110}$ Still, we provided a detailed empirical analysis on how a microfinancing organization consistently innovated its products, services and processes to improve financial inclusion through four programs and twenty activities overtime, and across countries at an in-depth level that few studies have done.

${ }^{110}$ www.nobelprize.org/prizes/economic-sciences/2019/press-release 
Our findings offer five insights that characterized how Grameen Foundation achieved innovation that MFIs, NGOs, governments, academia and policy makers can apply to their MF innovation programs based on: 1) Sensing country-specific needs; 2) Seizing opportunities to use existing technology; 3) Funding projects that drove innovation overtime, and the importance of multi-sectorial partnerships; 4) Transferring innovation to attain transformative scale; and 5) Strengthening the internal capabilities of how performance was measured, monitoring and evaluated for program outputs in order to sustain the scaling of outcomes.

We demonstrated that Dynamic Capabilities Theory concepts of sensing, seizing and transforming was very adaptable to studies of innovation in microfinance with the exception of VRIN resources because Grameen's philosophy of creating open-sourced market-based solutions that they shared with industry, translated this concept into Transferrable, Valuable, Imitable and Non Substitutable or "TVIN" resources. 


\section{APPENDICES}

\section{Appendix 1. Interview Questionnaire}

Dynamic Capabilities in Microfinance innovations: A Case Study of the Grameen Foundation

Interviewers: Dr. Lars Mathiassen (dissertation chair) and Sarah Kayongo (candidate)

\section{Research Question:}

"How do Microfinance Organizations innovate their products, services and processes to improve financial inclusion?"

\section{Interview Questions}

Note: The following questions represent the universe of questions that may be asked. Not all of these questions are relevant for all the informants and therefore the actual questions asked during interviews will depend on the informant's role within the organization. Moreover, since this study involves semi-structured interviews, other relevant questions may be generated during the course of an interview based on the informant's responses.

\begin{tabular}{|c|l|c|}
\hline \multicolumn{2}{|c|}{ A. Background } & \\
\hline 1. & What is your job title? & \\
\hline 2. & $\begin{array}{l}\text { How many years have you worked with the Grameen } \\
\text { Foundation? }\end{array}$ & Yes/No \\
\hline 3. & $\begin{array}{l}\text { Describe the specific role you (and/or your team) play in the } \\
\text { implementation and management of microfinancing solutions. }\end{array}$ & \\
\hline $\begin{array}{c}\text { 3b. } \\
\text { Old Vs. }\end{array}$ & $\begin{array}{l}\text { Did you work with the Old Grameen or Freedom from Hunger } \\
\text { prior to the merger? }\end{array}$ & \\
Grameen & $\begin{array}{l}\text { If yes, please describe how your current job is different from your } \\
\text { previous job. }\end{array}$ & \\
\hline \multicolumn{2}{|c|}{ 4. } \\
\hline $\begin{array}{l}\text { Below are some of the broad innovative financial solutions Grameen Foundation has } \\
\text { adapted to improve financial inclusion. }\end{array}$ \\
Please help me understand: \\
$\begin{array}{l}\text { a) For each of the innovative financial solution listed below, please describe their } \\
\text { products, services and processes. }\end{array}$ \\
$\begin{array}{l}\text { b) Describe how Grameen Foundation designs, implements and delivery microfinance } \\
\text { products, services and processes. }\end{array}$ \\
\hline
\end{tabular}




\begin{tabular}{|c|c|c|c|c|c|c|}
\hline $\begin{array}{l}1 . \\
\text { Digital } \\
\text { Products } \\
\text { \& } \\
\text { Services }\end{array}$ & $\begin{array}{l}2 . \\
\text { Financial } \\
\text { Agent } \\
\text { Networks } \\
\text { Salesforce }\end{array}$ & $\begin{array}{l}\text { 3. } \\
\text { Agriculture } \\
\text { Finance }\end{array}$ & $\begin{array}{l}\text { 4. } \\
\text { Bankers } \\
\text { without } \\
\text { Borders }\end{array}$ & $\begin{array}{l}5 . \\
\text { Health } \\
\text { Finance }\end{array}$ & $\begin{array}{l}\text { 6. } \\
\text { Integrated } \\
\text { solutions }\end{array}$ & $\begin{array}{l}7 . \\
\text { Other }\end{array}$ \\
\hline \multicolumn{7}{|c|}{ B. Design } \\
\hline 1. & \multicolumn{5}{|c|}{ Please describe the microfinance products, services and processes? } & \\
\hline 2. & \multicolumn{5}{|c|}{$\begin{array}{l}\text { Describe when this new microfinance products, services and } \\
\text { processes were designed. What circumstances triggered the design? }\end{array}$} & \\
\hline 3. & \multicolumn{5}{|c|}{$\begin{array}{l}\text { Describe how the design of this microfinance product, service or } \\
\text { process differs from the old Grameen and how it has changed } \\
\text { overtime /if applicable. }\end{array}$} & \\
\hline 4. & \multicolumn{5}{|c|}{$\begin{array}{l}\text { Describe the role stakeholders played in the identification and } \\
\text { design of this product, services and process. Stakeholders may } \\
\text { include microfinance institutions, telecommunication partners, } \\
\text { beneficiaries etc. }\end{array}$} & \\
\hline 5. & \multicolumn{5}{|c|}{$\begin{array}{l}\text { Describe the challenges and successes of Grameen's microfinance } \\
\text { design process. }\end{array}$} & \\
\hline \multicolumn{7}{|c|}{ C. Implementation } \\
\hline 1. & \multicolumn{5}{|c|}{$\begin{array}{l}\text { Describe how the product, service or process is implemented at } \\
\text { Grameen Foundation. }\end{array}$} & \\
\hline 2. & \multicolumn{5}{|c|}{$\begin{array}{l}\text { Describe how the implementation of microfinance (in } 1 \text { above) } \\
\text { differs from the old Grameen and how it has changed overtime/if } \\
\text { applicable. }\end{array}$} & \\
\hline 3. & \multicolumn{5}{|c|}{$\begin{array}{l}\text { When is a new innovation introduced during the design or } \\
\text { implementation stages? What factors trigger the introduction of } \\
\text { innovation? }\end{array}$} & \\
\hline 4. & \multicolumn{5}{|c|}{ How is outcome measured $(\mathrm{M} \& \mathrm{E}) ?$} & \\
\hline 5. & \multicolumn{5}{|c|}{$\begin{array}{l}\text { Describe when and how feedback is captured to/from the different } \\
\text { stakeholders e.g. beneficiaries, microfinance organizations etc. } \\
\text { during the implementation of microfinance }\end{array}$} & \\
\hline 6. & \multicolumn{5}{|c|}{$\begin{array}{l}\text { Describe the challenges and successes of Grameen's microfinance } \\
\text { implementation process. }\end{array}$} & \\
\hline \multicolumn{7}{|c|}{ D. Delivery } \\
\hline 1. & \multicolumn{5}{|c|}{$\begin{array}{l}\text { How has Grameen's microfinance delivery model changed since the } \\
\text { merger? How different is it now vs. its early days? }\end{array}$} & \\
\hline
\end{tabular}




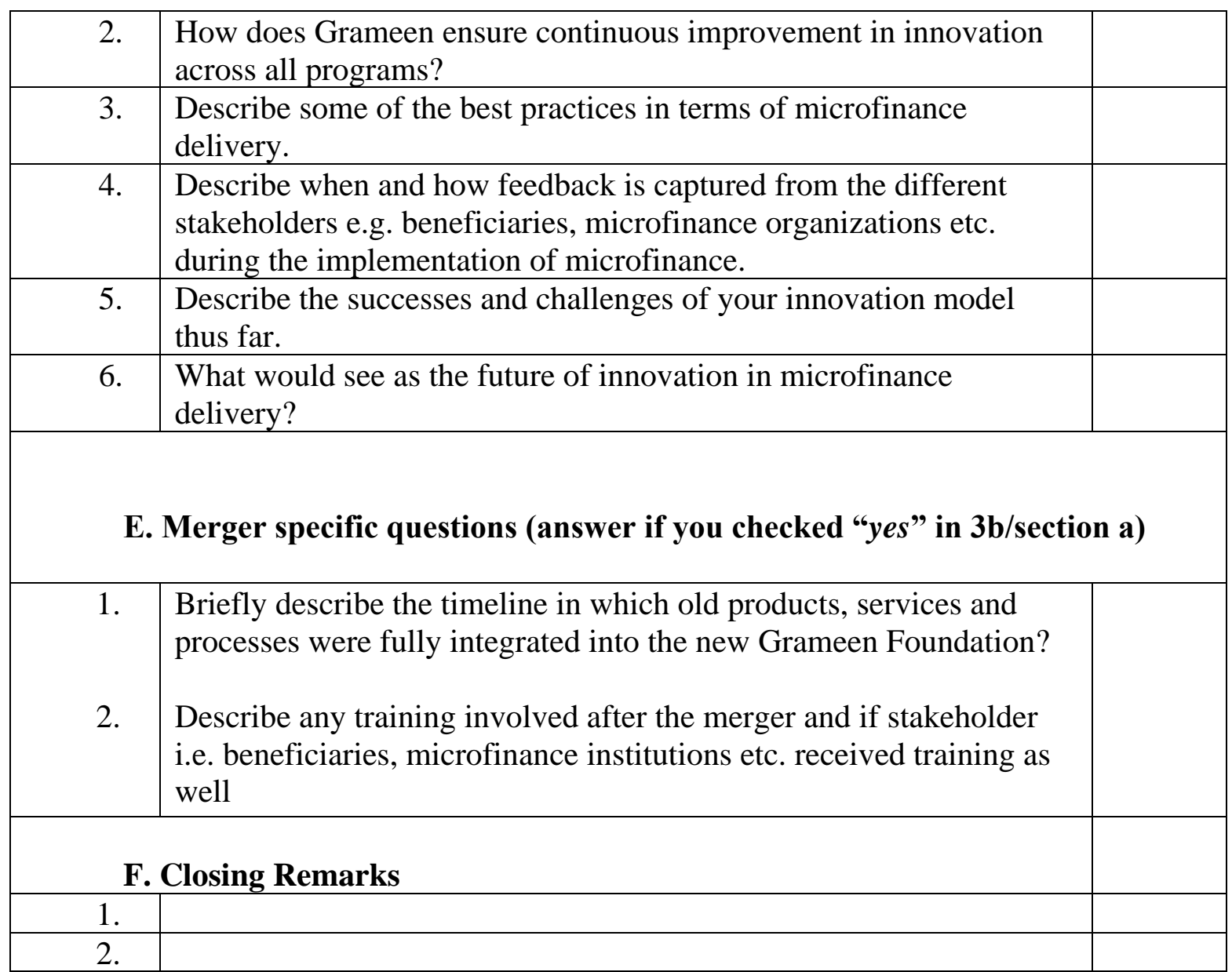

\section{Thank you for your time!}




\title{
Appendix 2. Informed Consent Form
}

\author{
Georgia State University \\ Center for Process Innovation \\ Informed Consent for Interview
}

Title: "Dynamic Capabilities in Microfinance Innovations: A Case Study of the Grameen Foundation"

Principal Investigator: Dr. Lars Mathiassen. Co-Investigators: Sarah Kayongo

I. Purpose:

You are invited to participate in a research study. The purpose of the study is to investigate how innovation in microfinance products, services and processes can be used to scale financial inclusion. You are chosen as a candidate for an interview because you are currently involved in managing and supporting the organization's microfinance initiatives. A total of 10 to 15 participants will be recruited for this study. The interview should take no more than one hour of your time.

\section{Procedures:}

If you volunteer for the study, you will be asked to participate in an interview. There are no right or wrong answers to questions asked in the interview. Please answer the questions honestly. Investigators will take notes during the interview. With your consent, your interview will also be digitally audio-recorded to facilitate data collection. The interview will be conducted by phone or in person at Grameen Foundation offices. The interview should take no more than one hour of your time. If necessary, we may ask you to participate in a follow up interview. The follow up interview should last no more than 30 minutes.

\section{Risks:}

In this study, you will not have any more risk than you would face in a normal day of life.

\section{Benefits:}

Participation in this study may not benefit you personally. However, we hope to gain a better understanding of how your organization may improve innovations in Microfinance products, services and processes to scale financial inclusion. Moreover, other NGOs and society may benefit from a deeper understanding from this study.

\section{Alternatives:}

The alternative to taking part in this study is not to take part in the study.

VI. Voluntary Participation and Withdrawal: 
Participation in this research is voluntary. If you decide to participate but change your mind later you have the right to drop out at any time. You may skip the interview or stop participating at any time. Whatever you decide, you will not lose any benefits to which you are otherwise entitled.

\section{Confidentiality:}

We will keep your records private to the extent allowed by law. The following people and entities will have access to the information you provide:

PI: Lars Mathiassen and Student Investigator: Sarah Kayongo

GSU Institutional Review Board istep:

Office for Human Research Protection (OHRP)

The information you provide will be stored as password-protected files on the PI's and student investigator's computers. These computers are protected by a username, password and firewall. When we present or publish the results of this study, we will not use your name or other information that may identify you. The code sheet, all paper documents and digital audio recordings produced for this research will be stored for two years and then destroyed. Your full name and other facts that might identify you will not appear when we present this study or publish its results. The findings will be summarized and reported in-group form. You will not be identified personally. [ispep?

\section{Contact Information:}

Please contact Dr. Lars Mathiassen at 404-413-7855

If you have questions about the study or your part in it. If you have questions, concerns, or complaints about the study.

Contact the GSU Office of Human Research Protections at 404-413-3500 or irb@ gsu.edu is:

If you have questions about your rights as a research participant. If you have questions, concerns, or complaints about the research.

\section{Copy of Consent Form to Subject:}

We will give you a copy of this consent form to keep.

If you are willing to volunteer for this research and be audio recorded, please sign below.

Participant

Principal Investigator or Researcher Obtaining Consent
Date

Date 


\section{Appendix 3. Inter-rater coding reliability assessment}

Sarah Kayongo and Dr. Yves Belmont 11/03/19

Sample: Interview Transcript, Grameen

Foundation

UTTERANCES

$\begin{array}{llll} & 2 & & 1 \\ & 3 & 2 & \\ 4 & 2 & \\ 5 & 2 & \\ & 6 & & 1 \\ 7 & 2 & \\ 8 & 2 & \\ 9 & & 1 \\ & 10 & & 1 \\ & 11 & 2 & \\ & 12 & 2 & \\ & 13 & 2 & \\ & & & \\ & & \text { AGREE } & \text { DISAGREE } \\ & 2 & \\ & 2 & 2 & \\ 3 & 2 & \\ 4 & 2 & \\ & 2 & \\ 6 & 2 & \\ 7 & 2 & \\ 8 & 2 & \\ 9 & 2 & \\ 10 & 2 & \\ 11 & 2 & \\ 12 & 2 & \\ 13 & 2 & \end{array}$

TOTAL AGREE

TOTAL DISAGREE

ICR \%

44

$\underline{4}$

$92 \%$

* Rating scale: Agree: 2,

Disagree: 1 


\section{REFERENCES}

Abbott, A. (1988). Transcending General Linear Reality. Sociology Theory, 6(2), 169-186.

Abeysekera, R., Patton, D., \& Mullineux, A. (2015). Co-production in Business Counselling in Microfinance Setting: A Conceptual Approach. Journal of Enterprising Culture, 23(3), 299-319.

Ahlin, C., \& Townsend, R. M. (2007). Selection into and across credit contracts: Theory and field research. Journal of Econometrics, 136(2), 665-698.

Ahlin, C., \& Townsend, R. M. (2007). Using repayment data to test across models of joint liability lending. Economic Journal, 117 (517), F11-F51.

Ahmed, J. U., \& Tinne, W. S. (2017). Cost-effective and sustainable microfinance model NGO in Bangladesh. South Asian Journal of Business and Management Cases, 6(2), 167-175.

Akerlof, G. A. (1970). The market for "lemons": Quality uncertainty and the market mechanism. The Quarterly Journal of Economics, 84(3), 488-500.

Allen, H. (2006). Village Savings and Loans Associations - sustainable and cost-effective rural finance. Small Enterprise Development, 17, 61-68.

Ambec, S., \& Treich, N. (2007). Roscas as financial agreements to cope with self-control problems. Journal of Development Economics, 82, 120-137.

Anderson, S., \& Baland, J. M. (2002). The economics of Roscas and intrahousehold resource allocation. Quarterly Journal of Economics, 117(3), 963-995.

Armendáriz de Aghion, B. (1999). On the design of a credit agreement with peer monitoring. Journal of Development Economics, 60, 79-104.

Armendáriz de Aghion, B., \& Gollier, C. (2000). Peer Group Formation in an Adverse Selection Model. Economic Journal, 110, 632-644. 
Armendáriz de Aghion, B., \& Morduch, J. (2010). The Economics of Microfinance (2nd Edition, Volume 1). Cambridge, MA: The MIT Press.

Assefa, E., Hermes, N., \& Meesters, A. (2013). Competition and the performance of microfinance institutions. Applied Financial Economics, 23(9), 767-782.

Banerjee, A., Duflo, E., Glennerster, R., \& Kinnan, C. (2009). The miracle of microfinance? Evidence from a randomized evaluation. Cambridge, Mass MIT Poverty Action Lab: MIT Poverty Action Lab.

Banerjee, A., Duflo, E., Glennerster, R., \& Kinnan, C. (2015). The Miracle of Microfinance? Evidence from a Randomized Evaluation. American Economic Journal: Applied Economics, 7(1), 22-53.

Banerjee, A. V., Besley, T., \& Guinnane, T. W. (1994). Thy neighbor's keeper: The design of a credit cooperative with theory and a test. Quarterly Journal of Economics, 109(2), 491515.

Batra, V., \& Sumanjeet, C. (2012). The state of microfinance in India: emergence, delivery models and issues. Journal of International Economics, 3, 69-92.

Bauchet, J., \& Dalal, A. (2009). Randomized experiments in microfinance. Microfinance Insight, $12,27-28$.

Beck, T., Demirgüç-Kunt, A., \& Levine, R. (2004). Finance, Inequality, and Poverty: CrossCountry Evidence. World Bank Policy Research Working Paper, 3338.

Besley, T., \& Coate, S. (1995). Group lending, repayment incentives and social collateral. Journal of Development Economics, 46, 1-18.

Besley, T., Coate, S., \& Loury, G. (1993). The economics of rotating savings and credit association. American Economic Review, 83, 792-810. 
Carlson, C. C., \& Wilmot, W. W. (2006). Innovation: The five disciplines for creating what customers want. New York: Crown Business.

Cho, S., Mathiassen, L., \& Nilsson, A. (2008). Contextual dynamics during health information systems implementation: an event-based actor-network approach. European Journal of Information Systems, 17, 614-630.

Chowdhury, P. R. (2005). Group-Lending: Sequential Financing, Lender Monitoring and Joint Liability. Journal of Development Economics, 77, 415-439.

Chowdhury, P. R. (2007). Group-lending with Sequential Financing, Contingent Renewal and Social Capital. Journal of Development Economics, 84, 487-507.

Christensen, C. M. (1997). The Innovator's Dilemma. Boston, MA: Harvard Business School Press.

Collins, D., Morduch, J., Rutherford, S., \& Ruthven, O. (2009). Portfolios of the poor: How the World's poor live on \$2 a day. Princeton, New Jersey, US: Princeton University Press.

Conlin, M. (1999). Peer group micro-lending programs in Canada and the United States. Journal of Development Economics, 60(1), 249-269.

Creed, W. E. D., Scully, M. A., \& Austin, J. R. (2002). Clothes Make the Person? The Tailoring of Legitimating Accounts and the Social Construction of Identity. Organization Science, $13(5), 475-496$.

Cull, R., Davis, L. E., Lamoreaux, N. R., \& Rosenthal, J. L. (2006). Historical financing of small and medium-size enterprises. Journal of Banking and Finance, 30, 3017-3042.

Cull, R., Demirgüç-Kunt, A., \& Morduch, J. (2007). Financial performance and outreach: A global analysis of leading microbanks. Economic Journal, 17(517), 107-133. 
Daley-Harris, S. (2009). State of the Microcredit Summit Campaign Report 2009. Retrieved from https://www.microcreditsummit.org

Das, S. G., Srinivasan, R., \& Kodamarty, M. (2010). Strategies to counter microfinance delivery challenges. SSRN Electronic Journal.

Demirgüç-Kunt, A., Honohan, P., \& Beck, T. (2008). Finance for all?: Policies and Pitfalls in Expanding Access (A World Bank policy research report ed.). Washington, D.C: World Bank.

Demirgüç-Kunt, J., Asli, L., Klapper, L., Singer, D., Ansar, S., \& Hess, J. (2018). The Global Findex Database 2017: Measuring Financial Inclusion and the Fintech Revolution. Washington, D.C.: World Bank.

Dornan, P., \& Pells, K. (2015). Building strong foundations for later livelihoods by addressing child poverty: evidence from Young Lives. Enterprise Development and Microfinance, 26(2), 90-103.

Eisenhardt, K., \& Bourgeois, L. J. (1988). Politics of strategic decision making in high velocity environments: Toward a mid-range theory. Academy of Management Journal, 31, 737770.

El-Gamal, M., El-Komi, M., Karlan, D., \& Osman, A. (2014). Bank-insured RoSCA for microfinance: experimental evidence in poor Egyptian villages. Journal of Economic Behavior \& Organization, 103, S56-S73.

Fernando, J. (2006). Microfinance. Perils and Prospects. London: Routledge.

Frederick, L. I. (2009). Information Technology Innovations That Extend Rural Microfinance. New Partnerships for Innovation in Microfinance. Berlin, Heidelberg: Springer-Verlag. 
Frederiksen, H. D., \& Mathiassen, L. (2008). A contextual approach to improving software metrics practices. IEEE Transactions on Engineering Management, 55(4), 602-616.

Ghatak, M. (2000). Screening by the company you keep: Joint liability lending and the peer selection effect. Economic Journal, 110, 601-631.

Ghatak, M., \& Guinnane, T. W. (1999). The Economics of Lending with Joint Liability: Theory and Practice. Journal of Development Economics, 60, 195-228.

Gioia, D. A., Corley, K. G., \& Hamilton, A. L. (2013). Seeking Qualitative Rigor in Inductive Research: Notes on the Gioia Methodology. Organizational Research Methods, 16(1), $15-31$.

Glaser, B. G., \& Strauss, A. L. (1977). The Discovery of Grounded Theory: Strategies for Qualitative Research. Chicago: Aldine Publishing.

Green, C. J., Kirkpatrick, C. H., \& Murinde, V. (2005). How does finance contribute to the development process and poverty reduction? Cheltenham, UK: Edward Elgar Publishing.

Guest, G., Bunce, A., \& Johnson, L. (2006). How Many Interviews Are Enough? : An Experiment with Data Saturation and Variability. Field Methods, 18(1), 59-82.

Hishigsuren, G. (2006). Transformation of Micro-finance Operations from NGO to Regulated MFI. USA: IDEAS.

Hulme, D., \& Mosley, P. (1996). Finance Against Poverty (Vol. 1. \& 2). London: Routledge.

Jain, S., \& Mansuri, G. (2003). A little at a time: the use of regularly scheduled repayments in microfinance programs. Journal of Development Economic, 72(1), 253-279.

Karlan, D. S. (2007). Social connections and group banking. Economic Journal, 117(517), F52F84. 
Karlan, D. S., \& Zinman, J. (2010). Expanding credit access: Using randomized supply decisions to estimate the impacts. Review of Financial Studies, 23(1), 433-464.

Khandker, S. R. (2005). Microfinance and poverty: Evidence using panel data from Bangladesh. World Bank Economic Review, 19(2), 263-286.

Khanvilkar, A. S. (2016). Challenges faced by microfinance institutions. Retrieved from https://www.nelito.com/blog/challenges-faced-microfinance-institutions.html

Krishnaswamy, K. (2007). Competition and multiple borrowing in the Indian microfinance sector. Chennai: IFMR, Centre for Micro Finance.

Landis, J. R., Koch, G. G. (1977). The measurement of observer agreement for categorical data. Biometrics 33:159-174.

Ledgerwood, J. (1998). Microfinance handbook: An Institutional and Financial Perspective. Washington, D.C: The World Bank.

Lee, A. S., \& Baskerville, R. L. (2003). Generalizing generalizability in information systems research. Information Systems Research, 14(3), 221-243.

Lempert, L. B. (2007). Asking Questions of the Data: Memo Writing in the Grounded Theory Tradition. CA: Thousand Oaks.

Lerpold, L. (2012). The contextualization of a microfinance model: from India to South Africa. Thunderbird International Business Review, 54(1), 117-129.

Levén, P., Holmström, A., \& Mathiassen, L. (2014). Managing research and innovation networks: Evidence from a government sponsored cross-industry program. Research Policy, 43, 156-168.

Levine, R. (1997). Financial development and economic growth. Journal of Economic Literature, 35, 688-726. 
Lincoln, Y. S., \& Guba, E. G. (1985). Naturalistic Inquiry. Newbury Park, CA: SAGE.

Locke, K., \& Golden-Biddle, K. (1997). Constructing opportunities for contribution: Structuring intertextual coherence and 'problematizing' in organizational studies. Academy of Management Journal, 40(5), 1023-1062.

Markus, M. L., \& Robey, D. (1988). Information technology and organizational change: causal structure in theory and research. Management Science, 34(5), 583-598.

Mathiassen, L. (2017). Designing Engaged Scholarship: From Real-World Problems to Research Publications. Engaged Management ReView, 1(1), 2.

Mathiassen, L., \& Vainio, A. M. (2007). Dynamic Capabilities in Small Software Firms: A Sense-and-Respond Approach. IEEE Transactions on Engineering Management, 54(3), 522-538.

Mayoux, L. (1999). Questioning virtuous spirals: Microfinance and women's empowerment in Africa. Journal of International Development, 11(7), 957-984.

Mayoux, L. (2010). Reaching and empowering women: towards a gender justice protocol for a diversified, inclusive, and sustainable financial sector. Perspectives on Global Development and Technology, 9, 581-600.

Mayoux, L. (2001). Tackling the down side: Social capital, women's empowerment and microfinance in Cameroon, Development and Change, 32(3), 421-50.

McIntosh, C., de Janvry, A., \& Sadoulet, E. (2005). How rising competition among microfinance institutions affects incumbent lenders. The Economic Journal, 115(506), 987-1004.

McIntosh, C., \& Wydick, B. (2005). Competition and microfinance. Journal of Development Economics, 78, 271-298. 
Mersland, R. (2009). Corporate governance and ownership in microfinance organizations. University of Agder, Kristiansand, Norway.

Mersland, R. (2009b). The cost of ownership in microfinance organizations. World Development, 37, 469-478.

Mersland, R., \& Strøm, R. Ø. (2010). The Impact of International Influence on Microbanks' Performance: A Global Survey Working Paper. University of Agder, Kristiansand, Norway.

Mersland, R., \& Strøm, R. Ø. (2012). The past and the future of innovations in microfinance. The Oxford Handbook of Entrepreneurial Finance, 859-891.

Mersland, R., \& Strøm, R.Ø. (2008). Performance and trade-offs in microfinance institutions Does ownership matter? Journal of International Development 20(5), 598-612.

Mersland, R., \& Strøm, R. Ø. (2008). The Empirics of Microfinance Lending Methodologies. SSRN. Retrieved from https://ssrn.com

Miles, M. B., \& Huberman, A. M. (1994). Qualitative Data Analysis (2nd ed.). Thousand Oaks, CA: Sage Publications.

Mohr, L. (1982). Explaining Organizational Behavior. San Francisco, CA: Jossey-Bass.

Morduch, J. (1999). The microfinance promise. Journal of Economic Literature, 37, 1569-1614.

Morduch, J. (2000). The microfinance schism. World Development, 28, 629- 629.

Morduch, J., \& Rutherford, S. (2003). Microfinance: analytical issues for India, essay prepared for World Bank. South Asia Region Finance and Private Sector Development.

Mosley, P., \& Hulme, D. (1998). Microenterprise finance: Is there a conflict between growth and poverty alleviation? World Development, 26, 783-790. 
Moturi, C., \& Mbiwa, P. (2015). An evaluation of the quality of management information systems used by SACCOs in Kenya. TQM Journal, 27(6), 798-813.

Navajas, S., Conning, J., \& Gonzalez-Vega, C. (2003). Lending technologies, competition and consolidation in the market for microfinance in Bolivia. Journal of International Development, 15(6), 747-770.

Newman, M., \& Robey, D. (1992). A Social Process Model of User-Analyst Relationships. MIS Quarterly, 16(2), 249-266.

Patton, M. Q. (2002). Qualitative research and evaluation methods (3rd ed.). Thousand Oaks, CA: Sage Publications.

Pettigrew, A. (1987). Context and action in the transformation of the firm. Journal of Management Studies, 24(6), 649-670.

Pitt, M. M., \& Khandker, S. R. (1998). The impact of group-based credit programs on poor households in Bangladesh: Does the gender of participants matter? Journal of Political Economy.

Prahalad, C. K. (2006). The Fortune at the Bottom of the Pyramid - Eradicating Poverty Through Profits. Upper Saddle River, NJ: Pearson Education - Wharton School Publishing.

Radeke, F. (2010). How to rigorously develop process theory using case research. ECIS 2010 Proceedings, 79.

Rai, A. S., \& Sjöström, T. (2004). Is Grameen lending efficient? Repayment Incentives and Insurance in Village Economies. Review of Economic Studies, 71(1), 217-234. 
Reille, X., Glisovic-Mezieres, J., \& Berthouzoz, Y. (2009). Microfinance Funds Continue to Grow Despite the Crisis (CGAP Brief. Washington, CGAP). Retrieved from https://www.cgap.org

Robinson, M.S. (2001). Microfinance Revolution: Sustainable Finance for the Poor. New York, NY: The World Bank.

Rogers, E. M. (2003). Diffusion of innovations (5th ed.). New York, USA: Free Press.

Roodman, D., \& Morduch, J. (2009). The impact of microcredit on the poor in Bangladesh: Revisiting the evidence. Working paper. Financial Access Initiative, New York.

Rothaermel, F. T. (2013). Strategic management: Concepts \& cases. New York,, NY: McGrawHill/Irwin.

Samaddar, S., \& Kadiyala, S. (2006). Information systems outsourcing: Replicating an existing framework in a different cultural context. Journal of Operations Management, 24(6), $910-931$.

Schumpeter, J. A. (1934). The Theory of Economic Development. Boston, MA: Harvard University Press, (Original: 1911).

Strauss, A., \& Corbin, J. (1990). Basics of Qualitative Research: Grounded Theory Procedures and Techniques. Newbury Park, CA: Sage.

Teece, D. J. (2007). Explicating dynamic capabilities: the nature and microfoundations of (sustainable) enterprise performance. Strategic Management Journal, 28(13), 1319-1350.

Teece, D. J. (2012). Dynamic capabilities: Routines versus entrepreneurial action. Journal of Management Studies 49(8), 1395-1401. 
Teece, D. J. (2014). The foundations of enterprise performance: Dynamic and ordinary capabilities in an (economic) theory of firms. Academy of management perspectives 28(4), 328-352.

Teece, D. J. (2018). Business models and dynamic capabilities. Long Range Planning 51(1), $40-49$.

Teece, D. J., Pisano, G., \& Shuen, A. (1997). Dynamic capabilities and strategic management. Strategic Management Journal 18(7), 509-533.

Tirole, J. (2006). The Theory of Corporate Finance. Princeton NJ: Princeton University Press.

Townsend, R. (1979). Optimal contracts and competitive markets with costly state verification. Journal of Economic Theory, 21(2), 265-293.

Van de Ven, A., Polley, D.E., Garud, R., \& Venkataraman, S. (1999). The innovation journey. New York: Oxford University Press.

Van de Ven, A. (1986). Central problems in the management of innovation. Management Science, 32(5), 590-607.

Van de Ven, A., \& Poole, M.S. (1995). Explaining development and change in organizations. Academy of Management Review, 20(3), 510-540.

Van de Ven, A. (2005). Running in packs to develop knowledge-intensive technologies. MIS Quarterly, 29 (2), 365-378.

van Leeuwensteijn, M., Bikker, J.A., van Rixtel, A.A.R.O.M., \& Kok Sørensen, C. (2007). A new approach to measuring competition in the loan markets of the euro area. European Central Bank. Working paper series, 768. 
Vogelgesang, U. (2003). Microfinance in times of crisis: The effects of competition, rising indebtedness, and economic crisis on repayment behavior. World Development 31, 20852114.

Von Pischke, J. D. (1996). Measuring the trade-off between outreach and sustainability of microenterprise lenders. Journal of International Development , 8(2), 225-239.

Wright, G.A.N., \& Rippey, P. (2003). The competitive environment in Uganda: implications for microfinance institutions and their clients. MicroSave, available at: http://www.microsave.net/files/pdf/The_Competitive_Environment_in_Uganda_Implicati ons_for_Microfinance_Institutions_and_their_Clients.pdf (accessed December 2018).

Wydick, B. (1999). Can social cohesion be harnessed to repair market failures? Evidence from group lending in Guatemala. Economic Journal, 109, 463-475.

Wydick, B. (2001). Group lending under dynamic incentives as a borrower discipline device. Review of Development Economics 5(3), 406-420.

Yin, R. K. (2003). Case Study Research: Design and Methods. Thousand Oaks, CA: Sage. Yin, R. K. (2014). Case Study Research Design and Methods (5th ed.). Thousand Oaks, CA: Sage.

Yunus, M. (1998). Banker to the Poor. London, UK: Aurum Press.

Yunus, M. (2004). Grameen Bank, Microcredit and Millennium Development Goals. Economic and Political Weekly, 39(36), 4077-4080.

Zeller, M. (1998). Determinants of repayment performance in credit groups: The role of program design, intragroup risk pooling, and social cohesion. Economic Development and Cultural Change, 46(3), 599-620. 
Zinman, J., \& Karlan, D.S. (2009). Expanding Microenterprise Credit Access: Using Randomized Supply Decisions to Estimate the Impacts in Manila. Yale Economics Department, Working Paper No. 68. 


\section{VITA}

\section{SARAH KAYONGO}

Telephone +1-404-645-4185• email: namukasasarah5@gmail.com•

\section{EDUCATION}

- Doctorate in Business Administration, Georgia State University, J. Mack Robinson College of Business. Graduation date: May 06, 2020.

- MSc. Economic Development, Eastern University, Saint David's, Pennsylvania.

- B.A. Business Administration, Messiah College, Grantham, Pennsylvania.

\section{PROFESSIONAL PROFILE OVERVIEW}

- A development economist with a versatile career in the NGO and private sectors with a successful track record of leading cross-functional teams in international settings and the USA. Adept at designing, implementing as well monitoring and evaluating economic development programs that strengthen the capabilities of poor communities to achieve sustainable impact.

- An experienced fundraiser, skilled at communicating complex economic development issues to multiple stakeholders such as: governments, the private sector, NGOs, civil society, academia, and development donors like USAID, USG, DFID, UN and AU.

- An astute negotiator, proficient at leveraging public private partnership to scale, country operations and country entry strategies in Ghana, Liberia, Nigeria, Malawi, Uganda, Rwanda, Nicaragua, Mexico, Ecuador, Ethiopia, India and Vietnam.

- An entrepreneur who co-founded Global Soap Project (now Clean the World), a social enterprise built on an innovative premise of soap recycling and distributing it to vulnerable populations in low-income countries. In 2011 Global Soap was recipient of the Top Ten CNN Heroes Award.

- Adjunct faculty, Non-profit Management at Oglethorpe University, Atlanta, Georgia.

- Several guest speaker appearances on financial inclusion and entrepreneurship to: universities, corporate groups, nonprofits, civil society, and African governments. 


\section{PEER-REVIEWED PUBLICATIONS}

Accepted manuscript (IJSE-02-2019-0125)

"Organizing and Orchestrating Microfinance Initiatives: A Contextualist Inquiry" (Kayongo, Tom \& Mathiassen).

\section{CONFERENCE PRESENTATIONS}

"Dynamic Capabilities in Microfinance Innovation: A Case Study of the Grameen Foundation"

Presented research in progress at a Doctoral Consortium and a Poster during the 9th Engaged Management Scholarship (EMS) conference hosted by the Antwerp Management School in Antwerp, Belgium on 09/05/2019.

Scheduled to present dissertation at the upcoming $10^{\text {th }}$ EMS Conference to be hosted by Case Western University on September 09/10/2020.

\section{INTERESTS AND FUTURE PLANS}

In spite of the success I attained in my career, I lacked a framework for decision-making, a grasp for analytical problem solving and the certainty of how to sustain that success in a global workplace where innovative skills quickly replaced longstanding ones. This program introduced me to the rigors of research through quantitative and qualitative methodologies, and to solving complex issues by applying evidence based management principles of engaged scholarship. My short-term career goal is to develop a resource guide based on findings gleaned from this and ongoing research, that practitioners of microfinance can access to facilitate their capabilities at improving the economic livelihoods of the two billion people in low income countries who lack access to financial services. As a researcher, I plan to publish in peer reviewed journals and to continue the discourse by presenting at international academic and practitioner conferences. In the long term, I plan to uphold a career that contributes to academia as a teacher and to grow in the application of evidence based management in economic development efforts that improve financial inclusion through innovation. 